STATE SECRETARIAT FOR ECONOMIC AFFAIRS (SECO)

WORLD TRADE INSTITUTE

FOREIGN TRADE UNIVERSITY

\title{
PARTICIPATION OF NON-STATE ACTORS IN FORMULATION OF TRADE POLICY IN VIETNAM
}

Hanoi, September 2013 


\title{
PARTICIPATION OF NON-STATE ACTORS IN FORMULATION OF TRADE POLICY IN VIETNAM
}

\author{
Research team: Dao Ngoc Tien ${ }^{1}(\mathrm{PhD})$ \\ Nguyen Quynh Huong (MA) \\ Nguyen Thu Hang (MA) \\ Ngo Chi Le (MA)
}

${ }^{1}$ Corresponding author at email: dntien@ftu.edu.vn 


\section{ACKNOWDLEDGMENT}

The authors would like to express our gratitude to the State Secretariat for Economic Affairs (SECO) and the World Trade Institute (WTI), in particular its Academic Cooperation Project, for supporting this research project,

Special thanks to Professor Pierre Sauvé from World Trade Institute for his supervision, valuable comment and guidance in this working paper.

Dao Ngoc Tien

Foreign Trade University, Vietnam 


\section{Table of Contents}

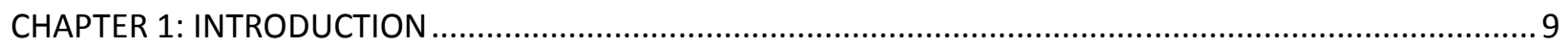

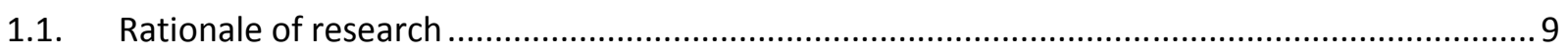

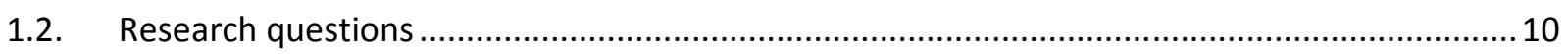

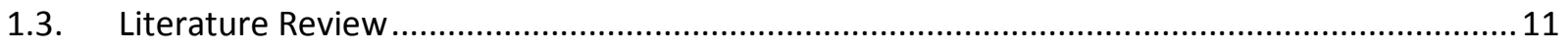

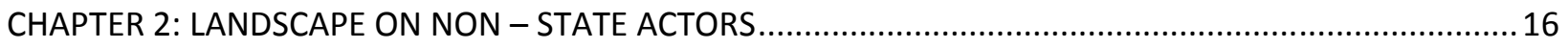

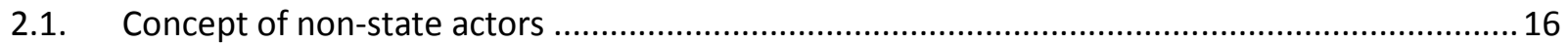

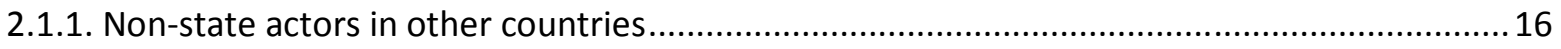

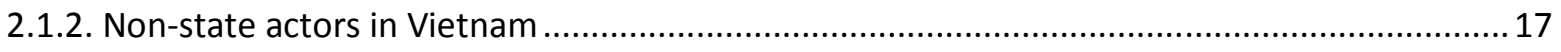

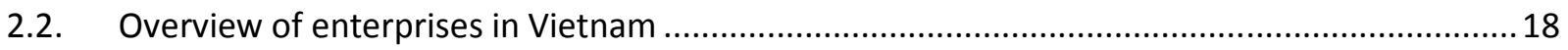

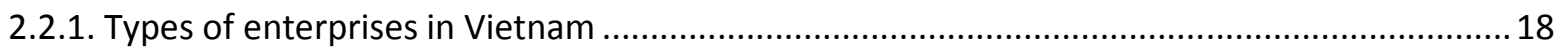

2.2.2. Pattern of goods export in Vietnam by kinds of economic sectors and industries .................21

2.2.3. Total revenue and density of enterprises in Hanoi and Hochiminh city................................ 22

2.2.4. Types and Management structure of State owned enterprises .......................................... 24

2.3. Overview of business /industry association/unions in Vietnam........................................... 24

2.4. Overview of civil societies (NGOs, Chambers of Commerce, Trade Unions) ............................ 26

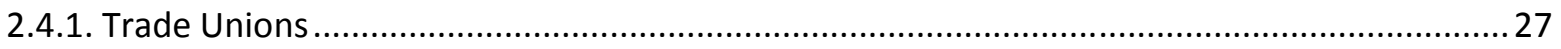

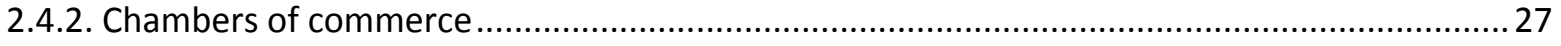

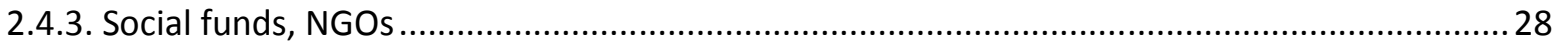

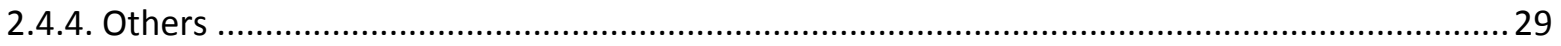

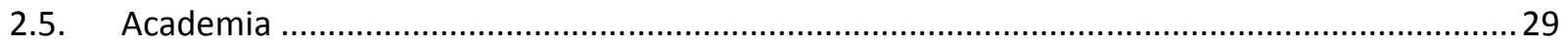

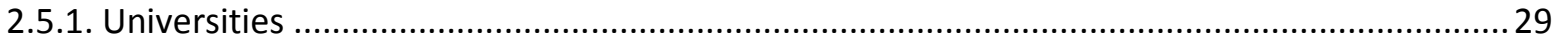

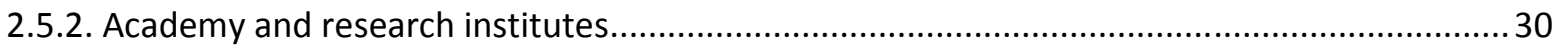

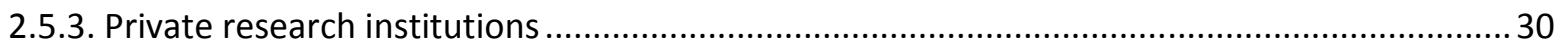

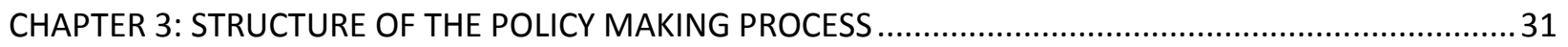


3.1. Overview of trade policy formulation in Vietnam ........................................................... 31

3.1.1. Formulation of commitment based trade policy ............................................................... 31

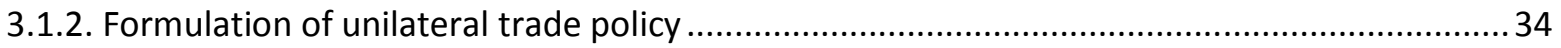

3.2. The structure of the trade policy making consultation mechanisms ..................................... 34

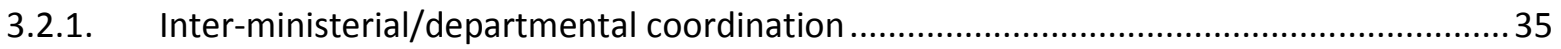

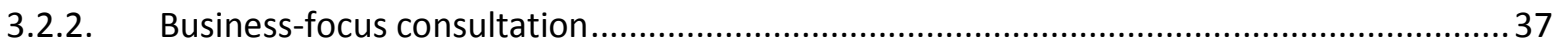

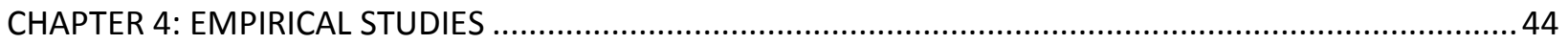

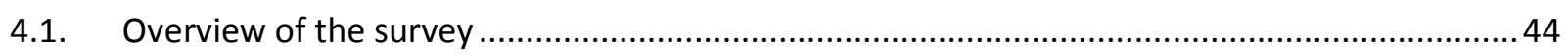

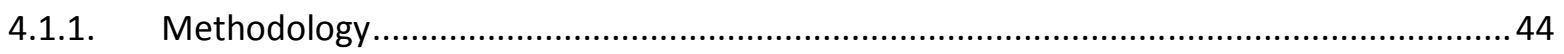

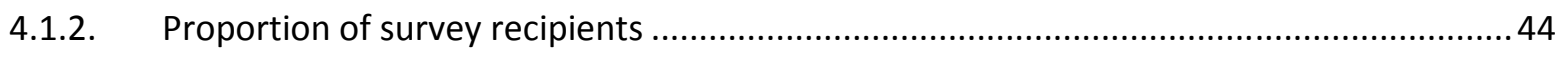

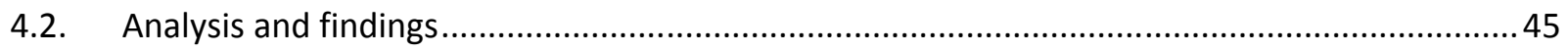

4.2.1. Why do actors participate in the trade policy consultation process? ..............................45

4.2.1.1. From the Government's perspective ..................................................................... 45

4.2.1.2. From non - state actors' perspective ................................................................. 46

4.2.2. Who are involved in the trade policy formulation? ....................................................... 48

4.2.3. How do actors involve in the trade policy making process in term of methods and content

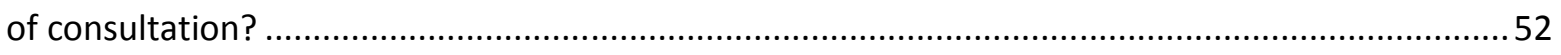

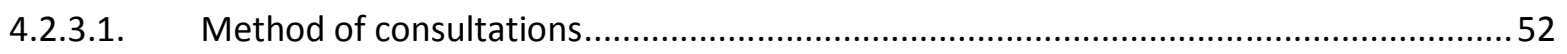

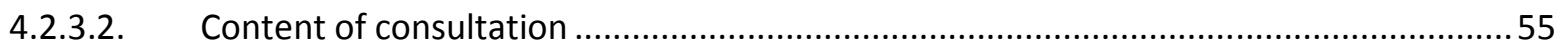

4.2.4. When does the trade policy consultation process occur? $\quad$..............................................5 57

4.2.5. What are the challenges in trade policy consultation process? .....................................60

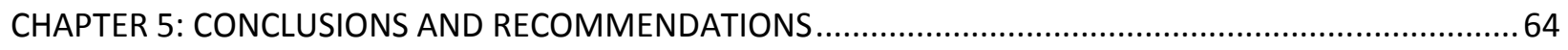

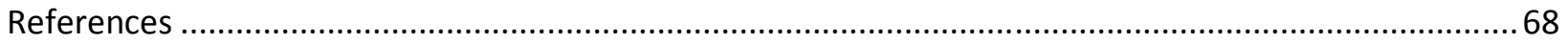

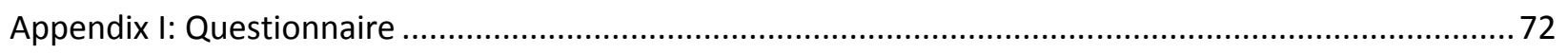

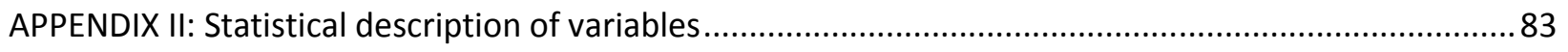

APPENDIX III: Statistical test of differences by Headquarter's location .................................................92

APPENDIX IV: Statistical test of differences by State-investment ....................................................... 97 


\section{List of tables}

Table 2.1: Number of enterprises by types in Hanoi and Hochiminh city year 2011 ......................23

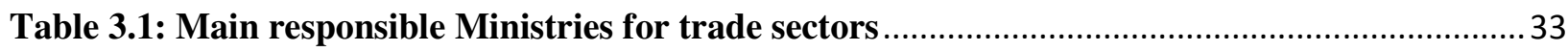

Table 3.2: Participation of stakeholders in negotiation for international trade agreements in



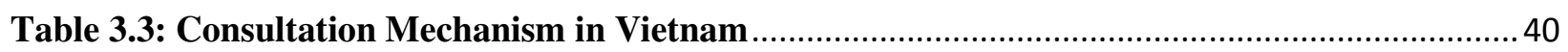

Table 4.1. The proportion of surveyed recipients ...................................................................... 44

Table 4.2. Reasons for government to carry out consultation in trade policy process ..................... 45

Table 4.3. Reasons for non-state actors to participate into trade policy process (by location) .......... 47

Table 4.4. Reasons for non-state actors to participate into trade policy process (divided by their

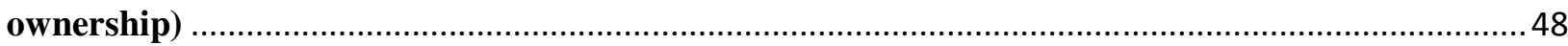

Table 4.5. Actors involving in trade policy formulation in Vietnam with frequency ........................49

Table 4.6. The frequency of consultation with other partners in trade policy process...................... 50

Table 4.7. The enterprises' targets of advocacies........................................................................ 51

Table 4.8. Ways of enterprise's engagement into trade policy on participation's methods...............53

Table 4.9. The government's ways to ask for consultation from non-state actors ............................54

Table 4.10. Enterprises' capability about trade policies ............................................................... 55

Table 4.11. The enterprises' attitude as the policy affects negatively their activities .......................56

Table 4.12. The importance of the enterprise's participation in formulation and implementation of

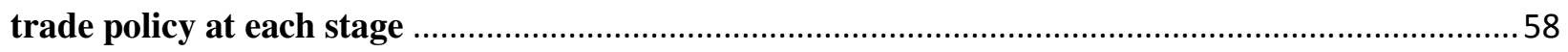

Table 4.13: Challenges preventing enterprises from further participating into ...............................60

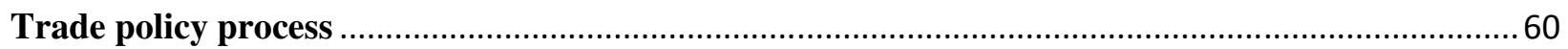




\section{List of figures}

Figure 2.1: Percentage share of Vietnam GDP by types of ownership of enterprises

Figure 2.2: Total revenue, profit and contribution to government's budget of Vietnamese State owned business groups and central corporations (in billions VND) 20

Figure 2.3: Percentage share of Vietnam GDP by non-state sectors............................................2 21

Figure 2.4: Pattern of Vietnamese exported goods by kinds of economic sectors (in percentage) .... 21

Figure 2.5: Pattern of Vietnamese exported goods by industries from 2005-2011 (in percentage) ...22

Figure 2.6: Turnover by types of enterprises in Hochiminh city and Hanoi year 2011 .23

Figure 2.7: Frequency of Vietnamese Association's consultation on enhancing the business environment per year 26

Figure 2.8: Main topics of the dialogues between associations and government offices.....................226

Figure 3.1: Formulation of commitment-based trade policy …....................................................... 31

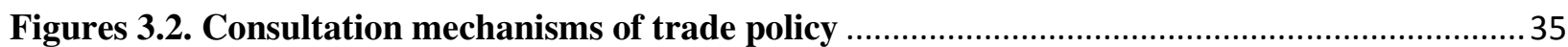

Figures 4.1. Managers in Vietnam Industry/Business Associations ............................................49

Figure 5.1. The spheres of State Actors and Non-State Actors in the trade formulation in Vietnam

\section{List of boxes}

Box 1: The operation of VCCI's Advisory Committee on International Trade Policy .....................39

Box 2: Low perception of enterprises on the Trans-Pacific Partnership Agreement at early stage .59

Box 3: Challenges to trade policy formulation in African countries 


\section{List of abbreviations}

$\begin{array}{ll}\text { APEC } & \text { Asia-Pacific Economic Cooperation } \\ \text { CITP } & \text { Committee on International Trade Policies } \\ \text { CSO } & \text { Civil Society Organization } \\ \text { EPA } & \text { Economic Preferential Agreement } \\ \text { FTA } & \text { Free Trade Agreement } \\ \text { INGO } & \text { International non-governmental organization } \\ \text { LEFASO } & \text { Leather and Footwear Association of Vietnam } \\ \text { MoET } & \text { Ministry of Education and Training } \\ \text { MoIT } & \text { Ministry of Industry and Trade } \\ \text { MoST } & \text { Ministry of Science and Technology } \\ \text { NA } & \text { National Assembly } \\ \text { NCIEC } & \text { National Committee on International Economic Cooperation } \\ \text { NGO } & \text { Non-governmental organization } \\ \text { NSA } & \text { Non-state actor } \\ \text { SME } & \text { Small and Medium sized Enterprises } \\ \text { TPP } & \text { Trans-Pacific Partnership } \\ \text { US } & \text { United States } \\ \text { VASEP } & \text { Vietnam Association of Seafood Exporters and Producers } \\ \text { VCCI } & \text { Vietnam's Chamber of Commerce and industry } \\ \text { VICOFA } & \text { Vietnam Association of Cocoa and Coffee } \\ \text { VITAS } & \text { Vietnam Association of textile and apparel } \\ \text { VUFO } & \text { Vietnam Union of Friendship Organization } \\ \text { WTO } & \text { World Trade Organization } \\ & \end{array}$




\section{CHAPTER 1: INTRODUCTION}

\subsection{Rationale of research}

In the nowadays global economy, international trading has become an essential part in the daily activities of all countries. Especially, export-import activities have become the locomotive for economic development of developing countries like Vietnam. Naturally, when it comes to export activities, one would like to enter markets with lower trade and non - trade barriers; which explains the need of governments to negotiate for lower tariffs, for instance, from their trading partners. Reciprocity basis would then require the exporting countries to as well open their markets for imported goods to come in more freely. However, often governments would try to protect their economy from the competition of imported goods and presence of foreign businessmen to some extent, especially when they want to nurture vulnerable industries. The export interest and import sensitivity do not go along together; hence, governments will have to make decisions: which domestic industries to protect with all cost? Which ones to trade off for market access into potential markets for strong export products? These decisions are realized in trade policies, and reflected in official documents between the governments of different countries, normally in the format of trade agreements, such as Free Trade Agreements (FTA) or a commitment/membership to a common trading framework (for example, the World Trade Organization (WTO) Agreement). Once governments bind their decisions in official documents, the country has to conform to its commitment, which can affect deeply the nature, the scale, the efficiency and the format of the business and activities of many sectors nation-wide. Needless to say, governments' decisions have to appropriately reflect the needs of the business community as a whole, after balancing interests of exporters and importers, of private sectors and public sectors, of other social groups. In the process of making decisions related to trading activities, or trade policy making process, governments need to be backed up with information from interest groups, especially the private sectors to have accurate calculation of benefits (e.g from exporting activities) vs. loss (e.g. from losing local market to foreign competitors). The information is necessary not only before the governments step in any trade negotiation (trade policy formulation) but as well after that, during the implementation of trade policy, so that any inappropriate steps can be revised somehow in the current policy or fixed in future commitment. This information feeding - processing - selecting - implementing process is referred to as trade policy consultation or participation of non - state sector in international trade policy.

Not only government will benefit from the participation of non - state actors in the trade policy making process, non - state actors also gain benefits from these opportunities. Non - state actors, especially private sectors, are heavily and directly affected from the implementation of trade policies in the countries. Therefore, if they succeed in delivering their concerns to the 
government, and have their interests reflected in the trade policies (e.g. opening foreign market access to their exporting products), their business activities will definitely boost up. Contrarily, if the trade policies contain unfavorable conditions for their activities (e.g. the government decides to open the domestic market of their sector), they will have to face fiercer challenges and competition. Participation in trade policy making process will possibly not only bring more opportunities and fewer challenges to non - state actors but as well prepare them for the outcomes of the process, i.e. the finalization of the policies and the implementation process. Participating in the trade policy consultation helps non - state actors to receive information on the direction of government's trade policy and helps them to be ready to reap opportunities and face with challenges.

In conclusion, participation of non - state actors in international trade policy formulation and implementation is very important for both government and non - state actors themselves.

\subsection{Research questions}

With the rationale set forth, the research team will seek to describe the roles of non - state actors in the trade policy making process in Vietnam within this paper. The research aims to answer following research questions:

Research question 1: Why do actors participate in the trade policy consultation process?

Research question 2: Who are involved in the trade policy formulation?

Research question 3: How do actors involve in the trade policy making process in term of methods and content of consultation?

Research question 4: When does the trade policy consultation process occur?

Research question 5: What are the challenges in trade policy consultation process?

In answering the above research questions, we analyze the perspectives of both enterprises (typically representative for non-state actors) and of the government towards the role of non state actors in the trade policy making process. The mismatch of reasons, methods, time, etc. of consultation between enterprises and government will expose problems in the Vietnam's trade policy consultation.

In addition, in the scope of this research, we try to find out the link between different enterprises' characteristics and the participation in trade policy formulation relating to the above research questions. Three characteristics of the company will be analysed in details, including:

- Location of company's headquarter either in the North or South of the country, which reflects the proximity to political actors. 
- Presence of state-owned capital, which implies a special channel to affect policy through ownership rather than consultation.

- Presence of foreign direct investment, which implies the market-based operation.

\subsection{Literature Review}

The complex process of foreign trade policy making involves and affects various actors whose relative importance has shifted as issues have changed and grown more diverse. This fact creates the need for multi stakeholder consultations and inclusive trade policy-making and implementation processes. Brian Hockling - Professor of International Relations, Coventry Business School, Coventry University, in World Trade Review 2004, showed that the growing trend towards the expansion and redefinition of trade consultative processes was another facet of the concern with transparency and access, which has become a crucial part of the debate on globalization and global governance, not least in the World Trade Organization (WTO). Moreover, establishing accountability and transparency in trade policy outside the borders of the state is engaged inevitably to their development inside the countries.

Nowadays, there has been a great deal of research on the role of non-state actors (i.e. enterprises and civil society organizations) contributing to the changes in the institutional mechanism and implementation of trade policy in countries. Researchers worldwide have been debating on the role and importance of non-state actors in the trade policy making process from various perspectives.

Hyun-Seok Yu (2003) in the paper on "Transnational Actors and Foreign Policy Making in South Korea: The Case Studies" demonstrated the increasing importance of non-state partners in Korea's foreign policy making with two case studies. The Council for the Women Drafted for Sexual Slavery by Japan case shows how international non-governmental organizations redefined issues so as to draw international attention and support from governments and other established international organizations. Their efforts compelled both the Korean and Japanese governments to alter policy. In the second case, the American Chamber of Commerce in Korea - a foreign based interest group for developing trade and commerce between Korea and the U.S. - succeeded in changing Korean and the U.S' foreign policies towards members' benefits through both direct lobbying and more back-channel tactics. However, the research did not advice the legitimacy and the specific mechanism for consultation.

Brian Hockling (2004), in his article: "Changing the terms of trade policy making: from the 'club' to the 'multi-stakeholder' model" showed the logic of trade consultation of the legitimacy 
and the involvement of a broader cross-section of interests as represented in enterprises and civil society organizations, particularly in NGOs. He examined with specific reference to the development of trade policy process in the Canadian and European Union contexts, then suggested that it was possible to analyze the development of at least some national trade policy environments in terms of a shift from a 'club', or through an 'adaptive club' to a 'multistakeholder' mode of consultation. The author affirmed that transforming closed systems into a multi-stakeholder model could embrace the expanding range of constituencies with an interest in the trade agenda, and that new 'rules of engagement' between the key sets of actors government, business and NGOs - were gradually being shaped, based on shared interests in trading resources - knowledge, legitimacy and access. However, the research did not reveal how the actors could make their roles in the trade policy process.

In July 2005, a research on "Trade Policy Reforms and Poverty in Kenya: Processes and Outcomes" of Walter Odhiambo and Gloria (KIPPRA) stated that there was limited participation of actors including the society, enterprises and State due to the absence of an effective cooperation mechanism among them. Later, in June 2007, KIPPRA executed a paper on "Trade Policy-Making Process in Kenya: The Institutional Arrangements and Interaction of Actors". The study identified factors that contribute to a process of developing, implementing and monitoring effective trade policies in Kenya, which calls for interaction between domestic and international factors. However, the study emphasized the role of the ministries and departments of the government, and mainly recommended enhancing such roles of these agencies in the process of trade policy making.

The research "Towards More Inclusive Trade Policy Making: Process and Role of Stakeholders in Select African Countries" published by CUTS international (2009) described the consultative mechanism for stakeholders' participation in five African countries (Kenya, Malawi, Tanzania, Uganda, and Zambia) anddocumented that the private sector had many more institutional mechanisms to interact with the government on different issues including trade. Hence, the general impression in project country stakeholders, particularly the civil society, that the private sector, particularly the apex business umbrella organizations as well as powerful sectoral organizations/individual firms have substantial influence on government trade policy making. Consequently, the paper gave a general impression on national stakeholders, the civil society in particular, that private sectors, especially the apex business umbrella organizations as well as powerful sectoral organizations/individual firms could have substantial influence on governmental trade policy making. However, there existed no single consultative mechanism with a legal mandate. Its role was generally to provide a discussion forum in which private actors were asked to provide inputs and advice regarding the country position in the WTO and Economic Preferential Agreements negotiations. Whether and how these views and advices 
were taken on board was not often published to non-governmental stakeholders; hence, those actors were often frustrated. This weakness of the mechanism needs to be seriously addressed.

In June 2009, Trevor Simumba published a paper in the Journal of the European Centre for Development Policy Management on "Private Sector Participation in Aid for Trade: Breaking Barriers to Private Sector Growth" and once again highlighted the role of the private enterprise sectors in coordination with the State to effectively implement a supporting package for commerce and trade development. The research proposed easing the cumbersome regulations, and gave some recommendations to eliminate barriers to the development of private enterprises.

In 2010, Ann Capling and Patrick Low, in the book: "Governments, Non-state actors and Trade Policy- making: Negotiating preferentially or multilaterally" indicated that the theories of trade policy-making relates to state-centric approaches, societal approaches and as well a synthetic approach. The research then conducted empirical studies in eight developing countries (Chile, Colombia, Mexico, Indonesia, Thailand, Jordan, Kenya, and South Africa) showing how nonstate actors saw their interests, participated and sought to influence the government. The specific case study could bring some lessons for inclusive participation of NSAs in trade policy process in countries. However, it focused only on the process of trade agreements negotiations and did not bring any conclusion on a clear mechanism with mandates.

Deepta Chopra (2010) studied the Indian government's role and interactions with the society in the realm of policy-making by conducting an empirical case study on the National Rural Employment Guarantee Act (NREGA) process in India, which had demonstrated the Government's consultation with the CSOs (Civil Society Organizations) during policy - making process. The consultation was considered a strategy for the Government to govern its population; and, in turn, the state itself was reconstituted in the policy - making process. Encapsulating from feedbacks in five countries in Africa (Kenya, Malawi, Uganda, Tanzania, and Zambia), Rashid S Kaukab (2010) in "Inclusiveness of Trade Policy-Making: Challenges and Possible Responses for Better Stakeholder Participation” gave some suggestions for better consultation with nonstate actors in trade policy- making process. Firstly, the government should build knowledge and expertise of all stakeholders on priority trade issues. Secondly, improving and providing regular information on trade issues to key actors was also necessary to promote general understanding and the quality of participation by stakeholders in consultations on trade. Thirdly, it was suggested that the government should rationalize and strengthen consultative mechanisms. Fourthly, they should improve the participation opportunities for CSOs, then balance representation of members' interests by private sector umbrella organizations. Finally, no improvement in capacity, co-ordination, mandates or procedures could have a lasting impact in the absence of dialogue and inclusiveness; therefore, the government should strengthen the 
culture of dialogue and inclusiveness. The author did not recommend an effective structure for inclusiveness and advice on legal regulations and ways to influence the policy making decision.

In the same vein of issue, Heng Wang with the research entitled "Enhancing Business Participation in Trade Policy-Making: Lessons from China" (The International Development Research Center) suggested that governments should increase the participation of the business sectors in the process of trade policy implementation. However, the research just suggested some recommendations but did not give a specific effective mechanism; additionally, the objective of this involvement mainly aims to enhance transparency according to China's WTO membership commitments.

In 2011, Kevin McKague published "Dynamic capabilities of institutional entrepreneurship" (Journal of Enterprising Communities: People and Places in the Global Economy), the first study to combine the institutional theory and the literature on dynamic capabilities to identify the necessary skills for businesses to successfully change the institution. However, this study was based on a specific case, leading to limited lessons to learn from. Research on more enterprises would be needed.

Professor Robert A. Rogowsky (President of Institute for Trade and Commercial Diplomacy) in his lecture on "Trade Negotiation" Training Course in Viet Nam (2012) showed the structure of trade formulation in the US including all stakeholder participation of United States Congress, Trade Policy staff committee (e.g. technical experts from ministries and other councils), Trade Policy Review Group (including US trade representatives and high level political officials from agencies) and Industry Trade Advisory Committees (including private sector, enterprises, NGOs, etc.). The working relation of those groups is regulated in the US's law, so that this mechanism works strongly and frequently for better trade policy decision. However, the implementation of trade policy and specific legal regulations should be studied deeper.

In Vietnam, the importance of the participation of non - state actors, especially enterprises, in the process of formulating and implementing international trade policy in Vietnam has not been thoroughly studied so far.

In 2009, Vietnam Chamber of Commerce and Industry (VCCI) implemented the program "Enterprises and International Trade Policy" to promote the effective participation of the business community in the process of policy making, negotiation and implementation of international trade commitments through three parallel mechanisms: the Advisory Committee of international trade policy, advocacy mechanism for flexible policy, and the awareness and capacity building on the international trade advocacy for the business association. These activities have been only in the very first stage and have not yet left any significant effects. 
In the same line of research, Professor Kenichi Ohno from the Japan Economic Research Institute shared his perspective on the process of strategic industry and policy formulation of Vietnam at the Vietnam Development Forum, confirmed that the process of policy making in Vietnam was one of a kind. Most policies were built with very limited involvement of the business. The business community was often allowed to give comments when it is too late, e.g. only after problems have arisen. In his conclusion, Kenichi Ohno recommended a policy-making process for Vietnam based on the lessons from other East Asian countries. Regrettably, the conclusion did not take into account factual situations in Vietnam.

Moreover, there are several related papers on online newspapers (e.g. "Business community in Vietnam \& the process of negotiation participation - executing international commitments: Good signs in 2011" ("Cộng đồng doanh nghiệp Việt Nam \& hành trình tham gia đàm phán- thưc thi cam kết quốc tế: Tín hiệu vui 2011)" (The journal of legislation - Tạp chí Pháp lý); "Mutual benefits" (“Lợi cả đôi đườn") (Institute of Southest Entrepreneur and Enterprise Development); "Reflect when looking at others" ( "Trông người mà ngẫm đến ta") (Vietnam leader) identifying the important role, the direction and the consequent benefits of the participation of enterprises in the process of trade policy formulation and implementation.

General speaking, the previous researches affirmed the importance of an inclusive participation of all stakeholders in trade policy process (formulation and implementation) as an evitable requirement for globalization and liberalization approach in all over the world, particularly in developing countries. Some countries have conducted the effective engagement of all stakeholders in some negotiations for Free Trade Agreements (FTAs) or Economic Preferential Agreements (EPAs). However, the weakness remains in the method to build an official mechanism with mandates to ensure legal powers that allow non-state actors to effectively and frequently cooperate with and influence the government. Besides, most of the papers mainly focused on trade policy formulation, and not much study was done on a structure for implementing trade policy. While some papers already suggested a better engagement of the business community into trade policy - making process, a formal mechanism for both trade policy formulation and implementation and specific legal regulations should be more thoroughly studied in the context of Vietnam. 


\section{CHAPTER 2: LANDSCAPE ON NON - STATE ACTORS}

\subsection{Concept of non-state actors}

\subsubsection{Non-state actors in other countries}

In the literature, the non-state actors have been defined differently and applied loosely depending on the research context and the settings of political system in different countries. While analyzing NSAs' roles in trade policy's decision making and forum choice (preference or multilateral trade agreement negotiation), Capling.A and Low.P (2010) regarded NSAs as both economic and socially-motivated NSAs. They commented that in the practice of trade policy formulation in different countries, not all the NSAs show their interest, raise their voice in the participatory dialogues or actively influence on the policy making process.

In the case of Chile, Herreros.S (2010) indicated that the Chilean business associations had been the most active NSA in preference trade agreement negotiations since 1990. For this country, labor organization, academic institutions and civil social organizations had participated in the process only since late 1990s.

Meanwhile, NSAs in Columbia which were interacting with Columbian state actors in the country's trade policies are business, farmers' associations and civil society organizations (Agriculture Salvation's organization and Health Mission) according to Gomez.H.J and Gamboa.J (2010).

In Mexico, Zabludovsky.J and Pasquel. L (2010) remarked that business sectors joined the consultation since this country's accession to GATT. Other Mexican NSAs who mainly negotiated NAFTA and PTAs such as "environmental and labour movement or academia" have recently showed less interest in the trade negotiation.

NSAs in Jordan, according to Khouri.R.A (2010), are business, professional and labour groups, private voluntary organizations. The researcher noted that there were "newer" NSAs who were at the effort to be more active since 1990s while the "old NSAs" were more powerful behind the scenes.

Introducing about the "Indian trade policy since the Uruguay Round", Dhar.B and Kallummal.M (2007) regarded "trade and industry associations, trade union, civil society organizations, massmedia, policy think-tanks" are non-state actors. 
In the study of the selected five African countries, Kaukab. S.R et al (2009) divided the non-state players in the international trade consultation into 2 groups: (i) multi-sector and sector umbrella private sectors (enterprises and business associations), and (ii) civil society organizations (CSOs) included NGOs, academia and CSOs network. In details, sector umbrella organizations of main industries in the project countries such as "tobacco, farming, exports", etc...represent both private and state-owned enterprises. The most dominant players in this type of NSAs are large scale companies who can be state-owned.

In short, for these brief cases of the above countries, NSAs were figured out as: (i) non-sovereign economic organizations that are industrial or business associations, farmer's associations, and (ii) civil social organization that are NGOs (labor organization, private volunteer organizations, chamber of commerce...), academia, and mass-media. They recently have seen their interests and showed their influence at different levels on the trade policy setting process via business consultations which are the discussing dialogues with the government agents.

\subsubsection{Non-state actors in Vietnam}

The NSAs in our research's scope is to some extents similar to the literature. We would like to clarify the participation of four NSAs groups in the trade policy making process in Vietnam. They are (i) Enterprises, (ii) Business associations, (iii) CSOs (including NGOs) and (iv) Academia (including universities and research institutes).

We would like to focus on the approach of non-state actors which is in the sense that the project actors are only able to intervene the trade policy making process indirectly and their benefit are under the impacts of the process.

The most significantly distinguished point of this project is that the individual enterprises have been taken into account due to their recently growing participation to the trade policy making process. Other key reason is since 2012, The Decision No.06/2012/QD-TTg shed the light on the mandatory consultations in international trade agreements between the government bodies and the "business community" including individual enterprises. The enterprises were used to be claimed that they had been neglect to the participatory dialogue with government agencies for formulation process or the policies' adjustment. Therefore in this project, we would carefully investigate this type of NSAs.

Other active NSAs in the process are the industry/business association which is one of the most crucial representatives of the enterprises. It can be argued that the industrial business associations are probably regarded as the representatives for evaluating the interactions of enterprises with the 
state players in trade policy forming. However, in Vietnam, it is not compulsory for the enterprises to be member of any industrial and business associations.

Local NGOs such as VCCI - the legal representatives of enterprises, and foreign NGOs (such as Eurocham, AmCharm, etc.) are supporters for both enterprises and government trade policy settings. The Academia are claimed to be ineffective given their efforts to make responses and arguments to the setting of trade policies.

The Labour Union/Trade Union in Vietnam is the representative NSA for workers supporting for their benefits in the trade policy in issues of forced labour, child labour, refugees, etc.... Recent interview with the Vietnamese WTO representative in Geneva (2013) revealed that during the negotiation stage for FTAs, the Vietnamese Ministry of Labour, War Invalids and social affairs is often in charge of labor related issues and the Trade Union is invited for consultations. However, the participation of the Trade Union to the trade policy making process in practice is not remarkable and it is excluded in this project's survey due to the constraint on related data and information.

The law firms are also the legal representative for the enterprises but in Vietnam they are frequently representing their local entrepreneur clients in dispute settlement issues, or assisting their foreign invested company clients for investment applying procedure. Because it is difficult to find the evidence to show that this type of NSAs implemented significant activities on trade policy lobby, they are not regarded as the surveyed object.

\subsection{Overview of enterprises in Vietnam}

\subsubsection{Types of enterprises in Vietnam}

The Enterprise Law of Vietnam (No. 60/2005/QH11) covers the following types of enterprises: Sole proprietorship, partnership, limited liability company, shareholding company (Articles 16 19), corporate group (Part VII). Among these types, companies can be either state owned (more or less than $50 \%$ capital invested by government's funds), or private owned (locally and foreign capital invested) or joint ventures (between foreign and local investors).

The issue of ownerships is discussed for inference since there would be an interesting question that whether the state-owned enterprises can be more active than the private-owned enterprises in lobbying the policy, or can press more influence on the policy makers since their management system is so far controlled by the government. The answer needs more facts which would be shown in the survey results to be confirmed. The following figure shows the shares of Vietnam GDP by these 3 sectors at current price: 


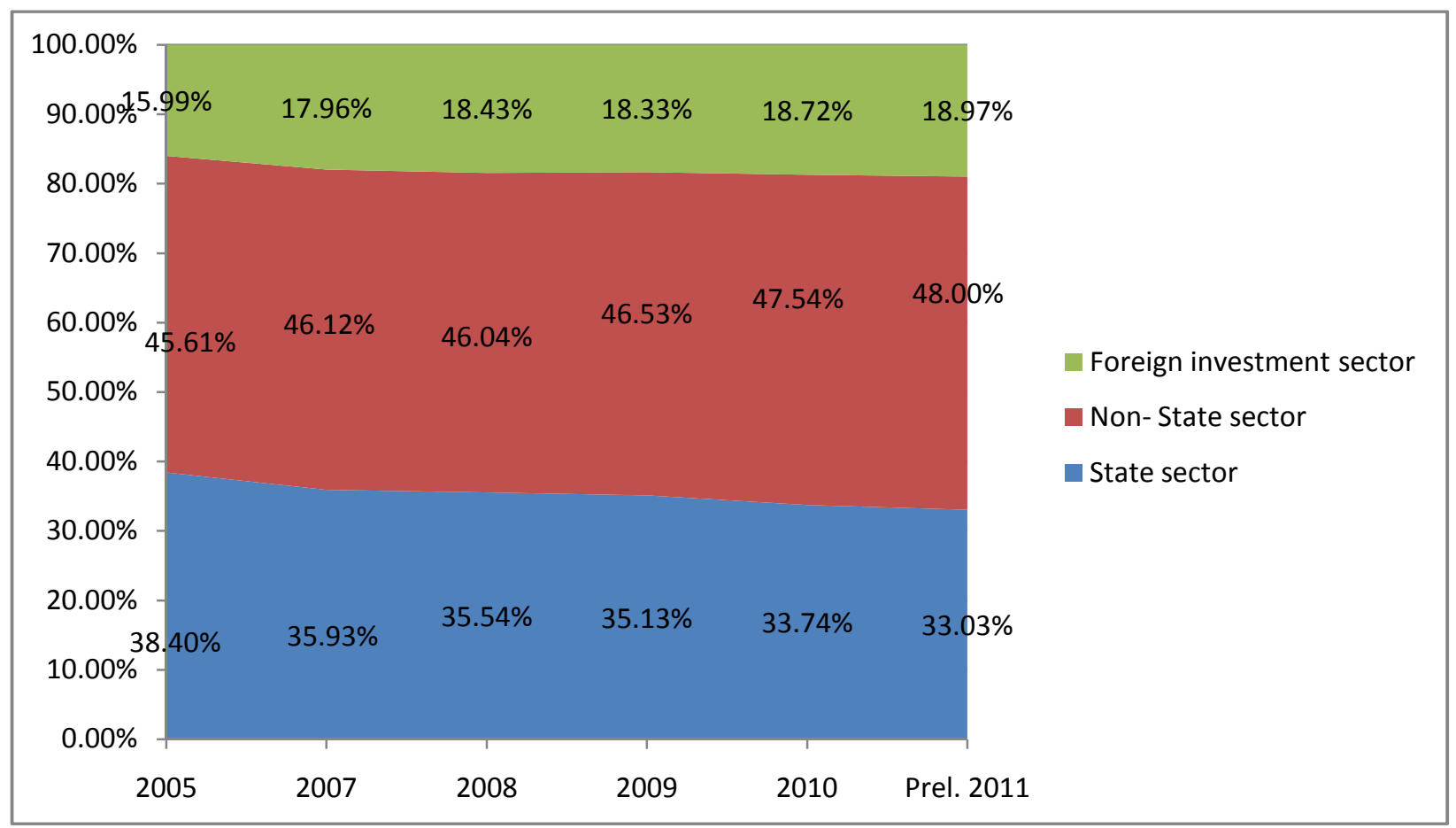

Figure 2.1: Percentage share of Vietnam GDP by types of ownership of enterprises

Source: Writer's calculation based on values of Vietnam GDP by types of ownership at current price (Billion Dongs) which was retrieved from GSO's website:

http://www.gso.gov.vn/default_en.aspx?tabid=468\&idmid=3\&ItemID=12978

The year 2006 is excluded due to the missing value in the GSO's website.

The figure reveals that the percentage share of GDP by non-state sectors has been gradually increasing since 2005. That rate is standing at $48 \%$ in 2011, which is just a mild change from $45.61 \%$ in 2005 . This shows the decreasing trend of the dominant role of state-owned sectors which has been regarded as the backbone of the Vietnam economy for years. Currently, stateowned sector in Vietnam are mostly large scaled enterprises carrying their business in most of main industries such as electricity, petrol, cement, constructions, energy and mineral resource, mining, transportations, telecommunications, capital, etc...

According to the report on Vietnamese government online portal, there are currently 11 state owned business groups (which are planned to be reduced to 7 groups) (Government Portal, 2013), and 16 state owned corporations. The following graph describes the trend of total revenue, profit and contribution (in billions VND) of state-owned business groups and central corporations for 5 years. During the periods of 4 years, given the fact that their revenue has been scaled up significantly, their profit was not at a racy growth rate due to the heavy burden of 
higher cost. In the graph, their profit either collapsed or stayed the same from 2008 which is the signal of the ineffective business management.

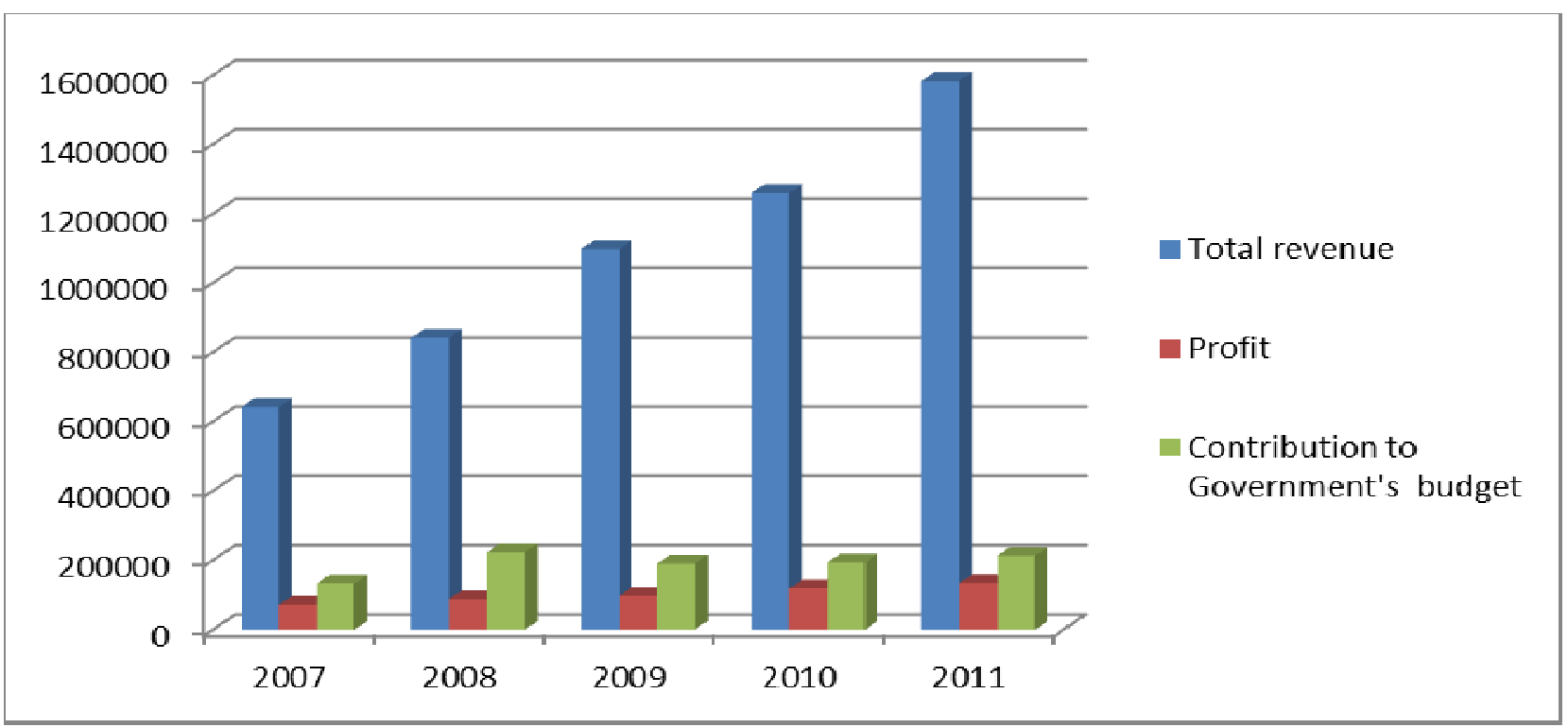

Figure 2.2: Total revenue, profit and contribution to government's budget of Vietnamese State owned business groups and central corporations (in billions VND)

Source: Vietnamese Ministry of Finance, report No. 336_BC_CP dated 16.11.2012, p.6

The contribution in percentage of the foreign investment sectors to this country's GDP also has not been at a big jump from nearly $16 \%$ to $19 \%$ in 6 years but remarked the higher growth rate of share of GDP comparing to the state-owned sectors. However, they have taken over business of more than $40 \%$ of the goods exporting from Vietnam, which has been showed in Figure 2.2.

The next graph gives more details about the percent of GDP contributed by non-state sectors. Among three non-state sectors, the household has attained the most significant contribution to the value of the final goods from 2005 to 2011 in Vietnam (the household is excluded from our research objects). The private sector has also playing a crucial role in the GDP with their contribution up to $12 \%$ for 6 observed years. This sector includes small and mediums enterprises and several large scaled enterprises. 


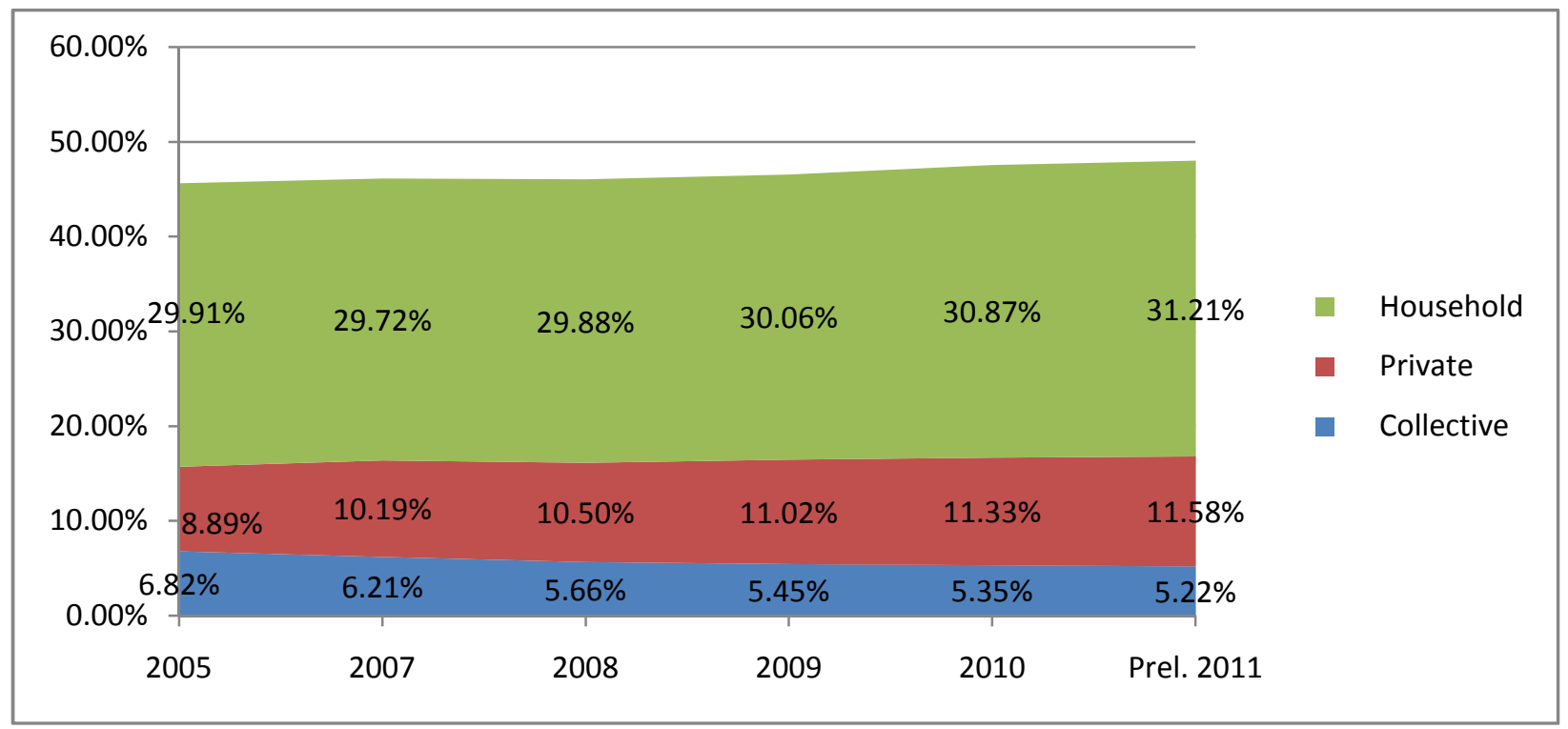

Figure 2.3: Percentage share of Vietnam GDP by non-state sectors

Source: Writer's calculation based on values of Vietnam GDP by types of ownership at current price (Billion Dongs) which was retrieved from GSO's website:

http://www.gso.gov.vn/default_en.aspx?tabid=468\&idmid=3\&ItemID=12978

The year 2006 is excluded due to the missing value in the GSO's website.

\subsubsection{Pattern of goods export in Vietnam by kinds of economic sectors and industries}

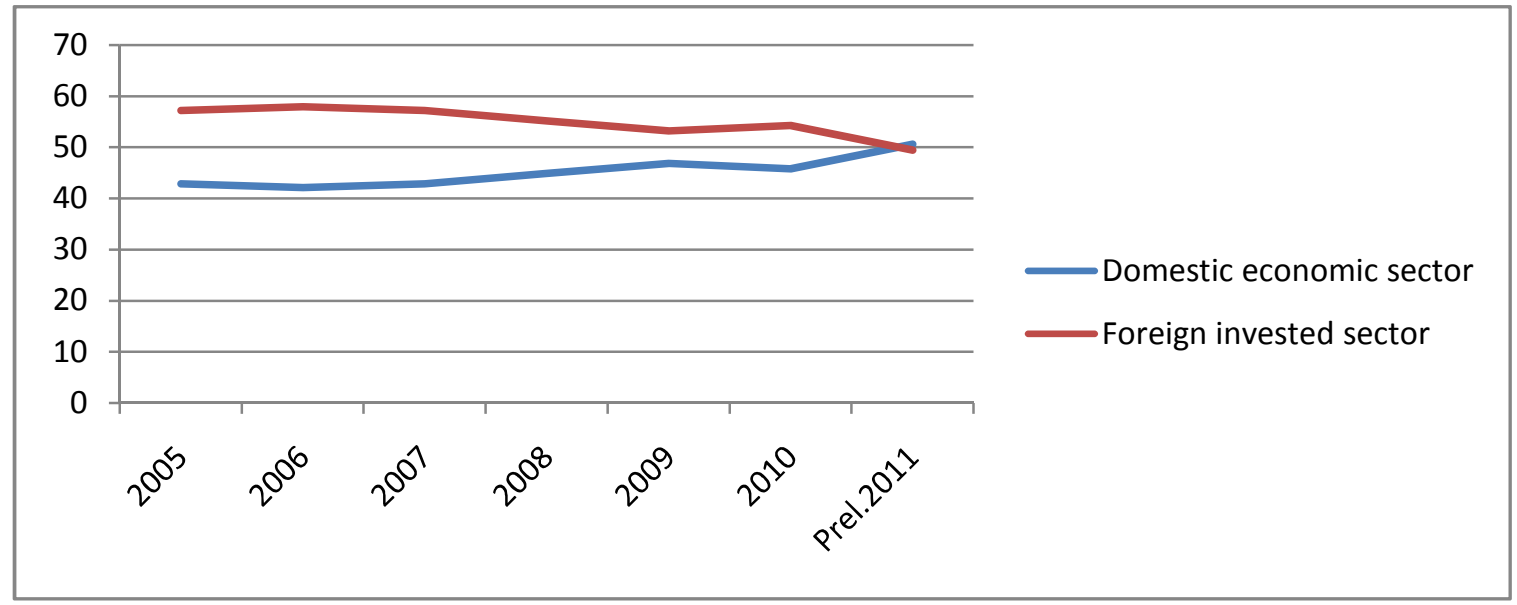

Figure 2.4: Pattern of Vietnamese exported goods by kinds of economic sectors (in percentage)

Source: GSO's website:

http://www.gso.gov.vn/default_en.aspx?tabid=472\&idmid=3\&ItemID=13215

In figure 2.4, the red line represents for the percentage of exporting goods that produced by foreign invested sector. It attained the higher rates comparing to the domestic economic sectors 
until 2010, then it started to decline in 2011. The reasons may come from the global recession in which foreign investors were under the higher pressure of crises. The next graph pictures the main industries' contribution to the country's total export value. Among others, the light industries and craft productions shows the highest percentage of the whole country's total export values in all observed years.

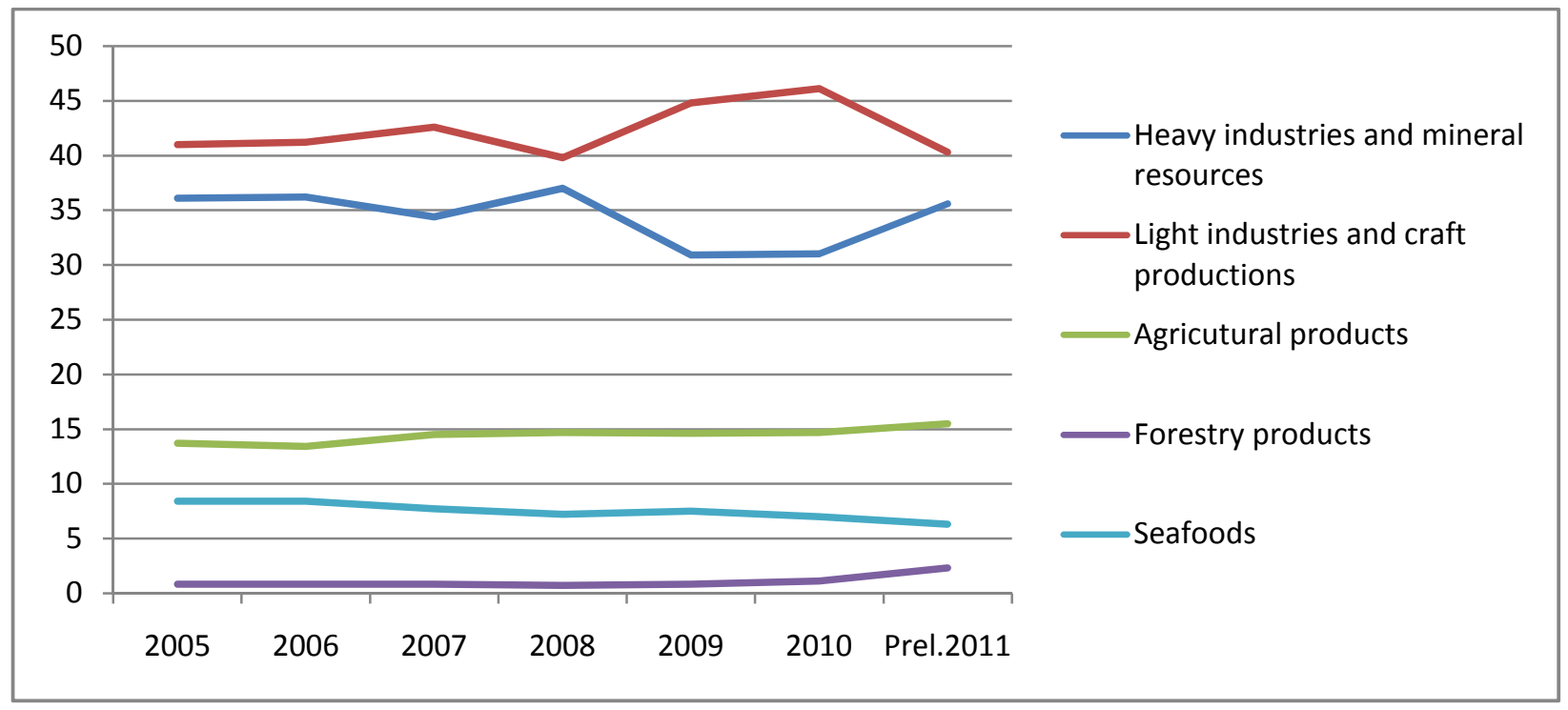

Figure 2.5: Pattern of Vietnamese exported goods by industries from 2005-2011 (in percentage)

Source: $\quad$ GSO's

website:

http://www.gso.gov.vn/default.aspx?tabid=393\&idmid=3\&ItemID=13173

\subsubsection{Total revenue and density of enterprises in Hanoi and Hochiminh city}

In further details, this part is aimed at picturing the density of companies (in number and in total revenue) in two biggest cities in Vietnam for reference of the survey conducted in the part for empirical studies. Since the survey will diagnose enterprises in which city will participate more actively to the trade formulation.

According to the Vietnamese enterprise census year 2011, the Vietnamese General Statistics organization divided the Vietnamese enterprises into 14 types. To simplify the research's questionnaire, our team rearranged these types into 5 types which are:

A. Local enterprises with more than $50 \%$ capital funded by the Government (equivalent to type 1-5 in the census).

B. Local enterprise with less than $50 \%$ capital funded by the Government (equivalent to type 9 and 11 in the census). 
C. Private local enterprise (without funding from the Government), (equivalent to type 6-8 and 10 in the census)

D. Joint - venture (equivalent to type 13 and 14 in the census).

E. Foreign owned enterprise (equivalent to type 12)

Figure 2.6 exhibits the total value of transactions carried by different types of enterprises in two biggest cities in Vietnam.

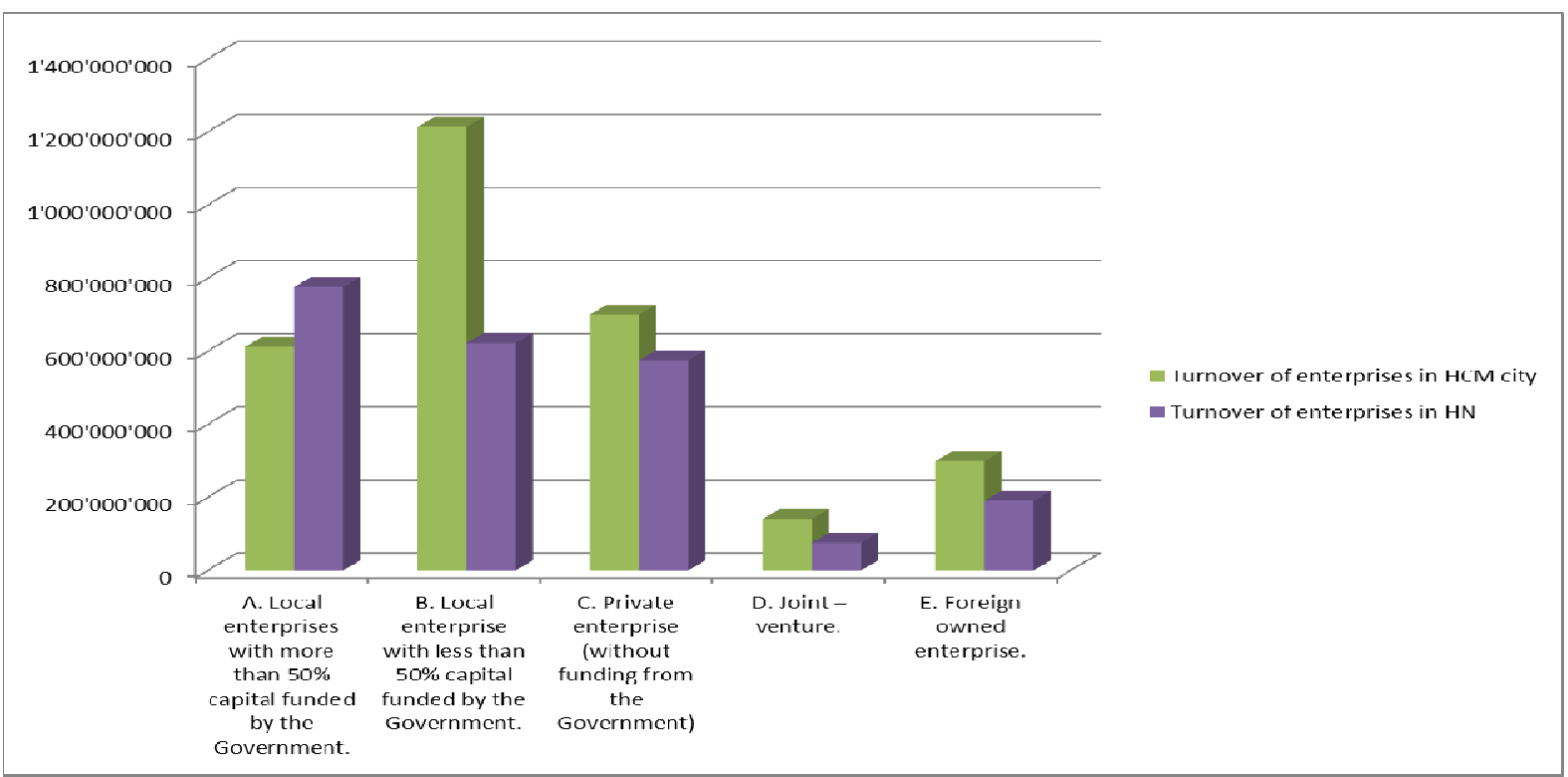

Figure 2.6: Turnover by types of enterprises in Hochiminh city and Hanoi year 2011 Source: Writer's calculation based on the Vietnamese Enterprises Census Year 2011 provided by $G S O$

In 2011, it is obvious that enterprises with type B,C,D and E in Hochiminh city in total gained higher revenues than ones in Hanoi, especially for the local enterprise with less than 50\% capital invested by the Government. In contrast, the local enterprises with more than $50 \%$ in Hanoi obtained more revenue than ones in Hochiminh city. One of the reason is that the number of companies typed A in Hanoi is 696 while in Hochiminh city this number is 506. Furthermore, 78,676 companies typed B in Hochiminh city is as more than twice as in Hanoi. Table 2.1 presents the number of enterprises in these two cities and displays the very high density of type $\mathrm{B}$ enterprises in Hochiminh city while the private enterprise (including collectives) locate less in this city than in Hanoi.

Table 2.1: Number of enterprises by types in Hanoi and Hochiminh city year 2011

\begin{tabular}{|l|r|r|}
\hline \multicolumn{1}{|c|}{ Types of enterprises } & \multicolumn{1}{c|}{ Hanoi } & Hochiminhcity \\
\hline A. Local enterprises with more than & 696 & 506 \\
\hline
\end{tabular}




\begin{tabular}{|l|r|r|}
$50 \%$ capital funded by the Government. & & \\
\hline $\begin{array}{l}\text { B. Local enterprise with less than } \\
50 \% \text { capital funded by the Government. }\end{array}$ & $35^{\prime} 868$ & $78^{\prime} 676$ \\
\hline $\begin{array}{l}\text { C. Private enterprise (without funding from the } \\
\text { Government) }\end{array}$ & $35^{\prime} 661$ & $22 ' 736$ \\
\hline D. Joint - venture. & 386 & 587 \\
\hline E. Foreignownedenterprise. & $1^{\prime} 791$ & $2 ' 759$ \\
\hline
\end{tabular}

Source: Writer's calculation based on the Vietnamese Enterprises Census Year 2011 provided by $G S O$

\subsubsection{Types and Management structure of State owned enterprises}

Obviously, the existence of state-owned enterprises dominates the joint venture, private and foreign owed enterprises in the business community. However, their contribution to GDP is not remarkably higher than these non-state enterprises. Their business have not been run effectively due to the very large scale and the complex decision making process inside the organization. Below we would like to give the overview of the state owned corporation 90 and state-own corporation 91 (business groups) to show that these types of entrepreneurs' business activities are currently still depending on the state's control but less than before.

The business groups were established since the Decision No.91/Ttg dated 07/03/1994 which board members appointed by the President and their capital have to be at least 1000 billion VND (roughly 47-49 million USD at current exchange rate). However, these types of business groups have been under the equitized since 2004. The state owned corporation 90 has been set up since the Decision No.91/Ttg was in forced. This type of company's manager was decided by Ministries and Local Committees with the minimum capital at 500 billion VND (roughly 23,524,5 million USD at current exchange rate). The number of both types has been collapsed to 27 core companies/groups since the government has been implementing the equitization and/or partial privatization for these inefficient ones.

\subsection{Overview of business /industry association/unions in Vietnam}

Assemblies, including associations, clubs, leagues, or unions (prescribed in Decree 45/2010/NDCP dated 21 April 2010, amended in Decree 33/2012/ND-CP dated 13 April 2012), defined as voluntary organization of Vietnamese citizens and organizations who share the same interests and unite for regular, not-for-profit activities [...] contributing to the economic development of the country. 
The Ministry of Industry and Trade lists 953 associations on their website, under "“"List of Vietnam's associtations". According to the MoIT, out of 953 associations, there are 121 associations operating in the field relating economy in Vietnam (Website of MOIT's associations, 2013). Those associations are established within one specific industry/business or around a certain group of enterprises.

Business/industry associations compose of enterprises operating in the same industry, such as VASEP (Vietnam Association of Seafood Exporters and Producers), VITAS (Vietnam Association of textile and apparel), LEFASO (Leather and Footwear Association of Vietnam) or VICOFA (Vietnam Association of Cocoa and Coffee). With their objectives of supporting enterprises members, the business associations will certainly lobbying policy toward providing benefits to their own industries. There are examples on the involvement of business associations in trade-related policy. For example, Vietnam Association of Motorcycle and Automobiles (VAMA) has tried to oppose the government's decision to lower tariff on automobiles (VEF, 2013). Recently, VITAS and LEFASO has actively participated in TPP's multi-stakeholder consultation to urge for the accessible opening of the US's market for textiles and apparels products (Youth newspaper, 2013).

Enterprises associations, such as SMEs associations, foreign-direct enterprises association or young/female enterprises association, compose of enterprises sharing same characteristics. With their wide range of operations, enterprise associations will be more neutral in policy consultation.

The VCCI had run a project on Evaluation of Vietnamese Association capacity conducting the survey on consultation/lobby for policies and legal regulations implemented by the Vietnamese enterprise associations for their members. There were several activities of the association have been analyzed in that project such as: consultation on strengthening business environment, research for policy lobby, organizing policy lobby campaigns, government and enterprise dialogues, setting up enterprise linkages, auctions in government procurement ...

In the following figures, the associations generally arrange meetings with government one or twice per year. At the national level, the associations take more opportunities for the participatory discussion with policy makers. However, the multi-industry associations at the local level have direct talks with representatives of the government bodies less often. 


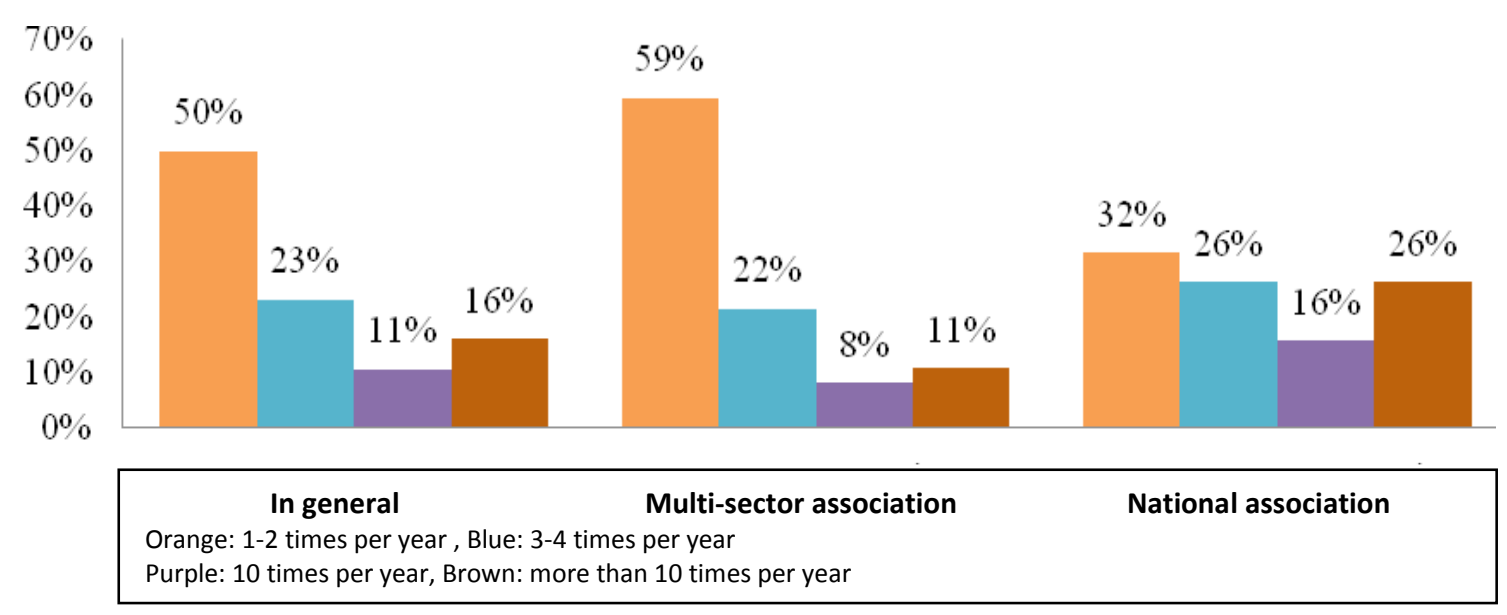

Figure 2.7: Frequency of Vietnamese Association's consultation on enhancing the business environment per year

Source: Report on Vietnamese Associations' capacity, VCCI (2013), p.70 \& p.75

According to the report, there are several main topics that the associations have been representing the enterprises to discuss with the authorities. The next graph visualizes the top issues in their interest which are Tax, Custom regulations; Land, Resources, and other topics include industry development policies, integration agreement commitments, monetary and financial policies...

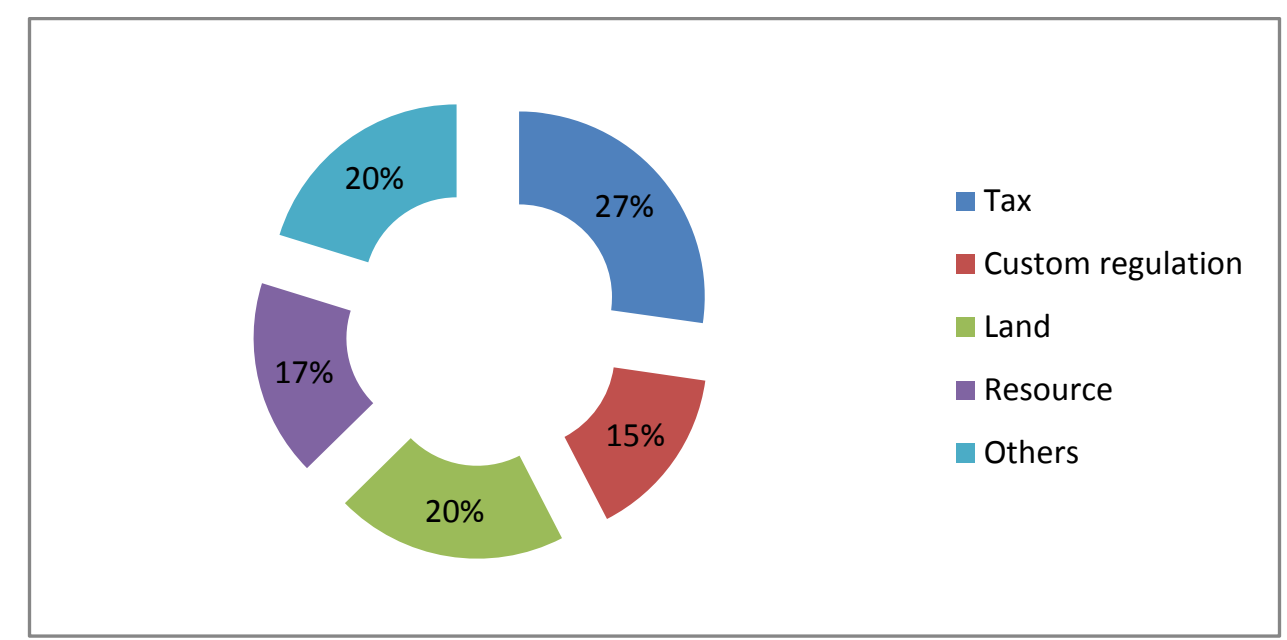

Figure 2.8: Main topics of the dialogues between associations and government offices

Source: Report on Vietnamese Associations' capacity, VCCI (2013), p.78

\subsection{Overview of civil societies (NGOs, Chambers of Commerce, Trade Unions)}

Distinction between different types of social organizations in Vietnam is not clear and there exists overlapping of definition and legal documents stipulating different types of social organizations. 
In general, social organizations which are recognized in the legal framework in Vietnam are divided into:

\subsubsection{Trade Unions}

According to official data from the government (Communist Party of Vietnam Online Newspaper, 2013), currently Vietnam has about eight million trade union members nationwide, representing close to $9 \%$ of the population (roughly 90 billion) and close to $16 \%$ of the workingage population (GSO counted 50.3 million of Vietnamese population of over 15 years old in 2011). Trade unions are stipulated under the Law on Trade union No. 12/2012/QH13 which only came into effect on 1 January 2013 (replacing the old one in 1990). All trade unions are facilitated under the Vietnam General Federation of Labor, which is a member of the Vietnam Fatherland Front and has strong tie with the Communist Party. Thus, trade unions, though trade unions might or might not be considered as non-state actors, they can hardly be considered independent entities. The research team excluded this type of entities from our scope of 'non state actors' recognition.

\subsubsection{Chambers of commerce}

Foreign chambers of commerce: There are a large number of foreign chambers of commerce established and run by members who are foreign investors/businessmen doing business in Vietnam. Those entities are driven by business interests of foreign investors/businessmen; hence, they are very dependent from the Vietnamese government and are often active in contributing to trade policy making process. Some very active ones to name: EuroCham, CanCham, AmCham, French/Korean Chamber of Commerce and Industry, etc. Foreign chambers of commerce have a long story of lobbying for their interests. One interesting example to note dated from 2001 when a coalition of local enterprises, American Chamber of commerce in Vietnam and other countries, American enterprises and international organizations (272 companies and associations in total) all signed a letter calling for Normal Trade Relations and the US-Vietnam BTA (US-Vietnam Trade Council, 2011).

Vietnam Chamber of Commerce and Industry (VCCI): An NGO as self-defined, VCCI "assembles and represents business community, employers and business associations of all economic sectors in Vietnam" (VCCI website, 2013). With more than 11,000 direct members and over 100,000 indirect ones, VCCI was appointed recently by the Deputy Prime Minister to 
be the focal point of business community in Vietnam, to actively contribute to policy-making and to monitor the Party's and State's business orientations (English VOV, 2013). VCCI's influential power and strong connect with the business community and the government is recognized by all international organizations in Vietnam and in many researches. VCCI also holds the key in comprehensive forums and seminars, for example, the Vietnam Business Forum (VCCI news, 2013). However, the role of VCCI is still influenced by the Government; for example, VCCI Chairman is also the Secretary of the Party Union of VCCI ("Nhan dan" (People) Magazine, 2013). Social protection facilities/care centers (prescribed in Decree 68/2008/ND-CP dated 30 May 2008 and Circular 07/2009/TT-BLDTBXH, amended in Decree 81/2012/ND-CP).

\subsubsection{Social funds, NGOs}

Social funds, or NGOs, are specified under Decree No. 148/2007/ND-CP dated 25 September 2007. The Decree aims to direct the organization and activities of charity funds and social funds, but define those funds as 'NGOs that have legal status, organized by one or more individuals or voluntary organizations volunteering to contribute a certain amount of money [...] with the aim of supporting cultural, educational, health, sport, scientific, charity and humanitarian activities for the society, not for profit purposes' (Article 3, Decree No. 148/2007/ND-CP). The Decree applies for Vietnamese individuals and organizations, joint ventures and enterprises with $100 \%$ foreign investment, as well as foreign individuals and organizations who contribute to the funds (Clause 2, Article 1, Decree No. 148/2007/ND-CP).

Foreign NGOs (herein referred to as International NGO or INGO) in Vietnam were formally administered under Decision 340/TTg from 1996, and from 1 June 2012, administered under Decree 12/2012/ND-CP (NGO Centre website, 2013) that came to effect on 1 June 2012.

Vietnamese government issues Certificates of Registration for three types of an INGO's status: a) Operations; b) Project Office and c) Representative Office. Applications for registration are to be sent to the Committee for Foreign NGO Affairs (COMINGO). The People's Aid Coordinating Committee (PACCOM) under the Vietnam Union of Friendship Organizations (VUFO) has the responsibility to work closely with INGOs and facilitate activities of INGOs in all provinces in Vietnam (NGO Centre, 2013).

INGOs, through the VUFO-NGO Center (The VUFO-NGO Resource Centre was established in 1993 through a partnership between INGOs working in Vietnam, and the Vietnam Union of Friendship Organisations (VUFO)), can have dialogues with the government institutions, and local NGOs. According to the survey made in 2003 of the VUFO-NGO Center, INGOs were 
very much interested in getting more information on new laws and regulations (74\% replied that this is their most concern) (Member survey of VUFO-NGO Centre, 2003). However, in the most recent annual report in 2009, VUFO-NGO Center announced that they have Working Groups to work with INGOs dealing with only: Agent Orange, Child Rights, Climate Change, Disability, Disaster Management, Ethnic Minorities, Eye Care, HIV/AIDS, Information and Communication Technology for Development, Landmines, Microfinance, and Water Supply and Sanitation. No Working Group was established to work with INGOs dealing with trade issues (Page 6, 2009 VUFO-NGO Centre Report). This shows the lack of contribution of INGOs connected to VUFO-NGO Center to trade policy making process. Consumer protection associations: In Vietnam, consumer protection associations are either under the umbrella of Ministries, or work as independent units. They do not deal directly with business/trade policy but rather protect consumers via raising awareness, reporting unsafe goods, etc.

\subsubsection{Others}

There exist as well other forms of social organizations such as think tanks or incubation centers for young entrepreneurs. Those organizations fall into the categories above, depending on the type of activities they carry out.

Except assemblies, all other types of local social organizations are considered serving the purposes of social/charity/humanitarian/scientific interests. They do not contribute to Traderelated policy making process.

\subsection{Academia}

The academia sector in Vietnam composes of different actors involving in either research or training activities in Vietnam as followed:

\subsubsection{Universities}

According to the law of education, university system in Vietnam is under the management of the MoET, except for 2 national universities. In 2012, there are 139 universities under the MoET, of which 109 are public universities and 30 are private. Those public universities focus more on the training than research activities, even though some plan to become research-based university. On the research side, the higher education system is not performing to expectation. According to the survey in 2012 by the World Bank, the research output of over 70 universities in Viet Nam is very worrying. This is explained by the very poor funding for research at universities. (Nguyen Ngoc Anh et.al, 2013) 
The research projects will be managed by MoET or MoST (for state-level project) from idea generation to results approval. There are representatives from other ministries involved in the whole process as member of evaluation boards but they are all acts on personal capacity. So, there is no evidence on the direct links of universities' research with the policy making.

\subsubsection{Academy and research institutes}

In addition to MoET's system of universities, there are academy and research institutes belonging to other ministries. They are all operating on the budget from those superior ministries. Similar to MoET's universities, academies, such as Diplomatic Academy of Vietnam (Ministry of Foreign Affairs) or Banking Academy (State Bank of Vietnam) has both training and researching functions. However, research institutes focus only on research activities, including strategy, plan and other projects as requested by their ministries.

In the field of trade policy, MoIT has 2 research Institutes of Trade (formerly belonging to Ministry of Trade) and Industrial Policy and Strategy Institute (formerly belonging to Ministry of Industry). Further discussions with those institutes reveal that they are in charge of helping minister to prepare strategy or proposal plan, which will be submitted to the Government for approval, while other ministries' functional department will be in charge of preparing legal document guidelining the implementation of the law or strategy under the form of decrees and circulars. In conclusion, research institutes maintain the important role in preparing strategies or feasible study to participate in FTAs (strategic policy) rather than regular participating in policy making.

\subsubsection{Private research institutions}

Scientific research institutions, scientific and technology development research centers, science and technology services centers (prescribed in Circular 02/2010/TT-BKHCN dated 18 March 2010), applied for all individuals and organizations who establish scientific and technology organizations, for profit or non-profit

In Vietnam, there are also private research institutions/research centres operating in Vietnam under Government Decree 115/ND-CP. According to MoST, there are 1661 private research institutes in Vietnam in 2013, but most of them in the fields of technical sciences. There are few institutions relating to trade, such as Development and Policy Centre (DEPOCEN), Mekong Economics, Indochina Research Centre (IRC), etc. However, they usually work on contracts with international organizations (WWB, UNIDO) to produce policy recommendation paper. In general, they are do not directly influence the policy of the government but rather through the international organizations. 


\section{CHAPTER 3: STRUCTURE OF THE POLICY MAKING PROCESS}

\subsection{Overview of trade policy formulation in Vietnam}

Trade policies can be defined as any regulations issued by the government that can directly or indirectly affect price or availability of goods and services (Nguyen H.N, 2009). This broad definition implies that trade policy in Vietnam can be a decree of any ministries or even an official document issued by ministerial-level agencies.

Similar to other countries, trade policy in Vietnam is reflected in either an international agreement or in the framework of the national law, which herein after will be called commitment - based and unilateral trade policy respectively. The former is promulgated to implement international commitment that Vietnam has made. In principles, in case of international commitment, Vietnam has to follow by promulgation and implementation of relevant policies.

The later, unilateral trade policy, is promulgated without international commitment but for the benefits of the country. In this case, Vietnam can change the policy whenever it finds necessary. Often, the distinction is not clear as Vietnam has promulgated new or revised current laws during the period of international negotiation. However, the formulation processes as well as legal basis are different in two cases.

\subsubsection{Formulation of commitment based trade policy}

As shown in the below flow chart, the formulation of commitment based trade policy in Vietnam includes 4 key stages:

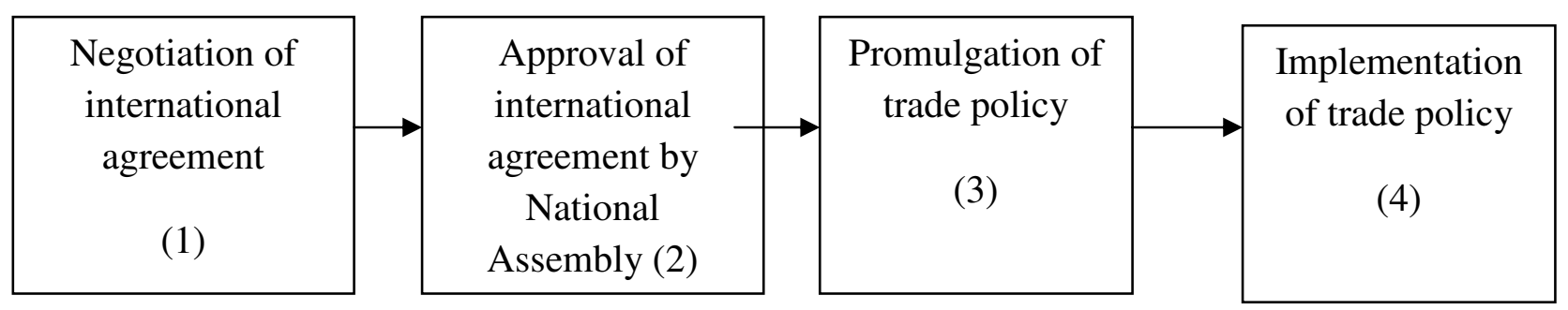

Figure 3.1: Formulation of commitment-based trade policy

According to the Law on signing, participation and implementation of international agreement (Law No.41/2995/QH11), the issue of participating of international agreement will be initiated by responsible ministry, then, be submitted to the government. There is normally is a feasibility 
study carried out by the ministry's research institute to serve as basis for the recommendation. The law also provides MOFA and MoJ to be mandatorily consulted while other ministries and relevant organization are not specifically mentioned. The decisions to join any international agreement or start the international negotiation are then made by the Prime Minister. It is assumed that before the Prime Minister makes these decisions; there are usually consultations between the government and the Socialist Party.

Within the country, legal documents of Vietnam are basically divided into 2 main tiers (i) Law, which is approved by the National Assembly; (ii) Decree and Circular, which is issued by relevant ministries guidelining the implementation of the Law. According to this classification, each governmental body plans its own annual schedule for legal documents development. At the highest level, the National assembly has its annual law and ordinance development program. Before approved by the National Assembly for the next year, the program is discussed among the NA's deputies, who represent the whole society. Among the national Assembly's deputies, 91.6\% are Communist Party's members and only 30.8\% are permanent members (National Assembly website, 2013). Consequently, there is concern that the National Assembly is affected by the Political Party as well as the government. At the lower lever, according to the NA's schedule, once the law is passed, relevant ministries will have plans to draft and issue decree and circulars accordingly.

In Vietnam, the decision on the policy on trade of goods concentrates in the Ministry of Industry and Trade (MoIT) but it relates to other ministries when the policy deals with specific issues. On the other hand, the decision on the policy on trade of services is scattered at different ministries. This fact is quite matched with the comment of Wolfe.R and Helmer.J (2007) that there exists the colliding as well as the overlapping between the domestic policies and the trade policies. Table 3.1 shows the current systematic relations among government agents in trade issues in Vietnam.

In addition to ministries, there is the Vietnamese National Committee for International Economic Cooperation (NCIEC) which was established and supervised directly by the Government. The NCIEC is one of the seven inter-industries coordination established by the Prime Minister but $d e$ facto, it belongs to MoIT. This Committee could bring in time interaction and information transparence on trade issues among governmental departments from the very early stage of trade policy formulation.

This system is not different from other countries' trade policy making model. Other counries also rely on an inter-ministries body to help connect different ministries regarding trade policies decisions. For instant, as mentioned by Worlfe.R and Helmer.J (2007), the Foreign Affairs of Norway and Brazil, or the Department of Trade of Canada, or the Netherland Economics Affair, 
or the Department of Commerce in India are all leading government bodies dealing with trade policies in their countries.

Table 3.1 demonstrates how responsibilities are divided among different ministries when dealing with trade policy decisions affecting different sectors. MoIT is mainly in charge of all issues related to Trade in Goods, while issues related to Trade in Services, Government procurement, or Dispute settlement issues fall into the control of different ministries.

Table 3.1: Main responsible Ministries for trade sectors

\begin{tabular}{|c|c|}
\hline Trade sector & Main responsible Ministries \\
\hline Trade in Goods & Ministry of Industry and Trade \\
\hline Trade in Agriculture, SPS issues & $\begin{array}{l}\text { Ministry of Agricultural and Rural } \\
\text { development }\end{array}$ \\
\hline TBT issues & Ministry of Science and Technology \\
\hline Government Procurement & Ministry of Planning and Investment \\
\hline Labour relating issues & $\begin{array}{l}\text { Ministry of Labour, War Invalids and social } \\
\text { affairs }\end{array}$ \\
\hline Dispute Settlement issues & Ministry of Justice \\
\hline Communication service & Ministry of Information and Communications \\
\hline $\begin{array}{l}\text { Construction and related engineering } \\
\text { service }\end{array}$ & Ministry of Construction \\
\hline Distribution service & Ministry of Industry and Trade \\
\hline Educational service & Ministry of Education and Training \\
\hline Environmental service & Ministry of Natural resources and Environment \\
\hline Financial service & $\begin{array}{l}\text { Ministry of Finance } \\
\text { State Bank of Vietnam }\end{array}$ \\
\hline Health related and Social services & $\begin{array}{l}\text { Ministry of Health } \\
\text { Ministry of Labour, War Invalids and social } \\
\text { affairs }\end{array}$ \\
\hline Tourism and travel related service & Ministry of Culture, Sport and tourism \\
\hline $\begin{array}{l}\text { Recreational, cultural and sporting } \\
\text { service }\end{array}$ & \\
\hline Transport service & Ministry of Transport \\
\hline
\end{tabular}

From the enterprises' views, the MoIT is the most influential ministry on their operation. Asking on the effects of ministerial policies, responded enterprises said rate MoIT's policy at 3.0 out of 4.0, which is highest among all the authorities and much higher than the compared with the overall average of 2.2 (authors' survey results, 2013). 
The authors' survey in 2013 shows that enterprises, whose headquarters located in the South, are affected by governmental policies more than those in the North. So, northern enterprises are expected to involve more in the process of policy formulation, which results in their preparation before the policy's promulgation.

\subsubsection{Formulation of unilateral trade policy}

Depending on the type of trade policy, there will be a particular ministry to be in charge of drafting the policy as mentioned above. During this period, there will be consultation among departments and ministries. At the end of this stage, the draft will be examined by Ministry of Justice (in particular, the Department of Examination of Legal Normative Documents).

As committed with WTO and stipulated in the Law of Domestic Legal Document Promulgation, the draft is required to be made available for public consultation. The draft law is usually placed in the website of relevant ministry and is open for public comments. Occasionally, relevant governmental body organize seminars/conferences to receive comments from selected non-state participants. Authors' interviews with government officials reveal that business associations and big enterprises are often invited rather than SMEs. However, the participation rate is just around $15 \%-20 \%$ of the sent-out invitation letters. On the other side, from the enterprises, it is often said that the comments has not been responded properly, so overtime, they become less and less interested in consultation. It might lead to concerns about the real application and efficiency of this requirement.

\subsection{The structure of the trade policy making consultation mechanisms}

Consultation is defined as the exchange of information through meeting, conference or any other medium. In the research studying the reality of trade policy making process in five African countries, Kaukab. S.R et al (2009, p.23) classified trade policy making consultation into three mechanisms: inter-ministerial coordination only; public and private sectors representatives fora only (business or enterprise focus consultation); and multi-stakeholders consultation (including government authorities, civil society and private sectors). 


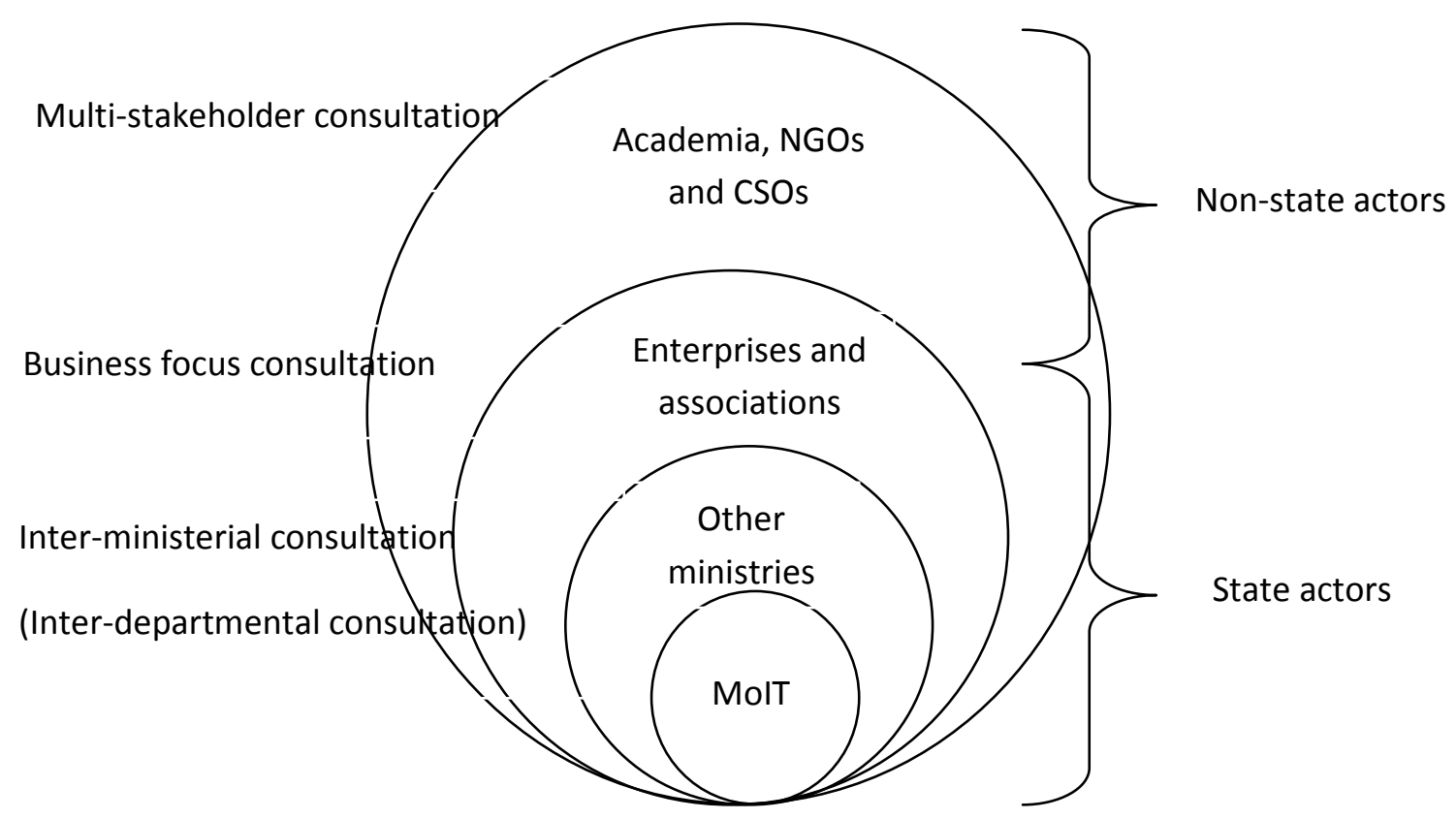

Figures 3.2. Consultation mechanisms of trade policy

Source: adapted from Kaukab. S.R et al (2009)

However, in Vietnam, as mentioned in previous chapter, the roles of civil society organizations and academia are limited, so, the multi-stakeholder consultation is not very popular. In this research, we will focus on the inter-ministerial coordination and business-focus consultations.

Before moving to empirical results, chapter 3 will describe the regime of how consultations are organized in Vietnam, i.e. how information flows are made available to the private sectors through the consultative activities, and through which networks, forum or agents the sectors would response or debate on the formulation and implementation of the trade policies. We would like to basically focus on the mechanism and legitimate requirements of trade policy making consultation.

\subsubsection{Inter-ministerial/departmental coordination}

The process of negotiation is led by Governmental Negotiation Delegation on International Economic and Trade which was established by Decision No 30/2003/QĐ-TTg dated 21/2/2003. According to this decision, the delegation, headed by a Deputy Minister of Industry and Trade, will draw member from other ministries on the on-the-job basis. Supporting the delegation is the Secretariat which is part of the National Committee on International Economic Cooperation (NCIEC). This inter-departmental structure of consultation mechanism has very well supported the Vietnamese Prime Minister in the negotiation stage since it plays the role as the bottom-up 
connection link crossing all departments of the government for information input. Similarly, India typically organized their inter-department committee which is National Trade Advisory Committee (NTAC) which members are their government department representatives. Wolfe. R and Helmer. J (2007) noted that Canada set up a C-Trade committee which has both the federal and provincial government representatives as well as 20 working groups from 17 federal agencies. The Netherland has their Inter-department Council for Trade Policy (IRHP).

In short, the Vietnamese Governmental Negotiation Delegation is responsible for the interdepartmental consultation, and the Vietnamese NCIEC is the government body assisting for the delegation. With the members assigned from Ministries and Government Departments, the Delegation and the Committee have also taken the role of business focus consultation to support the Prime Minister and all Ministries for the international trade agreements on different sectors. However, they did not involve directly in the multi-stakeholders. In the case of Malawi, Kaukab R.S et al (2009) indicated that this African country designed their own National working group on Trade policies which is not only advising the government on trade issues but also facilitating the consultation among public and private sectors.

Table 3.2: Participation of stakeholders in negotiation for international trade agreements in Vietnam

\begin{tabular}{|c|c|c|c|}
\hline Stages & Who are consulted & Who does consult & How are consulted \\
\hline $\begin{array}{l}\text { Initiation of the } \\
\text { negotiation }\end{array}$ & $\begin{array}{l}\text { Vietnam } \\
\text { Communist Party } \\
\text { Governmental } \\
\text { research institute }\end{array}$ & $\begin{array}{l}\text { National } \\
\text { Committee for } \\
\text { International } \\
\text { Economics } \\
\text { Cooperation } \\
\text { (NCIEC) }\end{array}$ & $\begin{array}{l}\text { Internal and secret } \\
\text { (assumed Pre-feasibility study) }\end{array}$ \\
\hline $\begin{array}{l}\text { Feasibility } \\
\text { study of the } \\
\text { negotiation }\end{array}$ & $\begin{array}{l}\text { Business } \\
\text { communities }\end{array}$ & $\begin{array}{l}\text { Competent } \\
\text { Authorities } \\
\text { Vietnam Chamber } \\
\text { of Commercial } \\
\text { Industries (VCCI), } \\
\text { The Committee on } \\
\text { International Trade } \\
\text { Policies }\end{array}$ & $\begin{array}{l}\text { Competent Authorities' Websites } \\
\text { Emails } \\
\text { Conferences (open and/or } \\
\text { confidential) } \\
\text { Others } \\
\text { (considered by the competent } \\
\text { authorities) }\end{array}$ \\
\hline Negotiation & $\begin{array}{l}\text { Business } \\
\text { communities }\end{array}$ & $\begin{array}{l}\text { Vietnam Chamber } \\
\text { of Commercial } \\
\text { Industries (VCCI), } \\
\text { The Committee on }\end{array}$ & $\begin{array}{l}\text { Competent Authorities' Websites } \\
\text { Emails } \\
\text { Conferences (open and/or } \\
\text { confidential) }\end{array}$ \\
\hline
\end{tabular}




\begin{tabular}{|l|l|l|l|}
\hline & & $\begin{array}{l}\text { International Trade } \\
\text { Policies } \\
\text { Competent } \\
\text { Authorities }\end{array}$ & $\begin{array}{l}\text { Others } \\
\text { (considered by the competent } \\
\text { authorities) }\end{array}$ \\
\hline $\begin{array}{l}\text { Approval of } \\
\text { agreement by } \\
\begin{array}{l}\text { National } \\
\text { Assembly (NA) }\end{array}\end{array}$ & $\begin{array}{l}\text { All go through } \\
\text { deputies to NA }\end{array}$ & $\begin{array}{l}\text { Macro-Advisory } \\
\text { Group }\end{array}$ & $\begin{array}{l}\text { Research report } \\
\text { Conferences/seminars }\end{array}$ \\
\hline
\end{tabular}

\subsubsection{Business-focus consultation}

Before 2012, there is no mandatory system in Vietnam for the consultation of non-state sectors in the stage of international trade agreement negotiation. However, under the management of the VCCI, the Committee on International Trade Policies (CITP) was initiated in January 2010. This focal agent has acted as the forum for the voice of both private sectors and government bodies on international trade issues. Interestingly, therefore, they are to some extents able to play their role both in the inter-ministerial consultation mechanism and the multi-stakeholders consultation mechanism in Vietnam. CITP's members include representatives of business associations in crucial industries, experts from competent authorities such as the National Assembly, the International Cooperation Department of the Vietnamese Ministries, Office of the Government and Experts from Universities, etc. Their missions are to support the authorities in the international trade agreement negotiation in providing the necessary input and domestic consensus as well as to assist the agreement implementation. Meanwhile, they would pass the opinions of business communities to the competent governmental bodies in regards to the negotiating and implementing international trade commitments, informing them the progress and the feedback.

Hence, the Vietnamese private sectors normally could contact the competent governmental bodies via agents such as VCCI or CITP for their suggestions, their proposal of modification of existing or on-going formulated trade policies. However, CITP only can influence on the trade policy maker to some limited extents since their consultation with the government bodies and enterprises is not compulsory in Vietnam.

Since January 2012, the Vietnamese Prime Minister issued Decision No.06/2012/QD-TTg on consultation with the business community on international trade agreements setting requirements for consultation at this stage. Who is the interested group for this multiple-stakeholders consultation? Then the interesting question is whether they are really efficiently involved into the consultation mechanism; which will be left for the later primary data analysis in this research. 
According to the scope of this Decision", it regulates the "consultation between agencies (which are ministry, ministerial level agencies, government attached agencies or negotiation delegation established by competent authorities to assume the prime responsibility for negotiating an international trade agreement with one ore more than one partner) responsible for negotiation and the Vietnamese business community in the process of preparing and negotiating international trade agreements". Business community which is referred in this Decision is limited within only "Vietnamese enterprises defined under the Enterprise Law, business associations and lawful representative agencies and organizations of these enterprises as provided by Vietnamese law". Dordi. C (2012) commented after the issuance of this Decision that the Vietnamese reluctant enterprises had been supported with the "lobby instruments".

The decision required delegations to provide "minimum" information including the Decision on kick-start international trade negotiation/feasibility study on trade negotiation, email address and website of the agencies being responsible for the negotiation, trade partners, deadline for responses from the communities through e-mail and website to private sectors. The private sectors then could directly response to the government agencies being responsible for the international trade agreements or through Vietnam Chamber of Commerce and Industry (VCCI). The competent agencies also have responsibilities to provide VCCI related information including typical market opening agreements in which the trade partners had signed with the third party; market opening agreements with third party equivalent to the on-going negotiated agreements; time schedule for conferences, meetings with the business community if happens.

The TPP, VN-EU FTA and Vietnam-Korea FTAs were those first international agreements subjected to the decision. Obviously, the decision had paved the crucial way of top-down information transferring to the private sectors. This reveals the existence of multi-stakeholders consultation as the compulsory legitimacy requirements in Vietnam.

So far, at the first glance, all the stakeholders and the governmental system have been connected in the "mutual talk" forum. The legislative regulation has made the information available and created opportunities for the private sectors to make use of it. It strongly enhances the transparency of the trade policies. Perhaps after the Decision 06/2012/QD-TTg, the "room next door consultation" does fully exist in Vietnam with the participation of the private players into the international trade negotiation. As noted by Dordi.C (2012), there were more than 20 recommendations sent to the Government until mid of June 2012.

\footnotetext{
${ }^{2}$ Translated version of the Decision No.06/2012/QD-TTg can be downloaded from http://lawfirm.vn/?a=doc\&id=2511
} 
There are questions that whether and how much the feedbacks from the business community are taken into account in the final decision of the international trade agreement? Those will be reconsidered later in the statistics results and the final comments.

Upon conclusion of negotiation, the agreements are required by the Constitution to go through National Assembly (NA) for approval. Up to now, there is no case that the international agreement is rejected by the Vietnam's NA. Recently, under a UNDP-sponsored projects, Macro-Advisory Group was established to provide research-based report and information to NA's deputies to support them in the approval process.

\section{Box 1: The operation of VCCI's Advisory Committee on International Trade Policy}

The VCCI's Advisory committee on International Trade Policy was established as part of the project "Enterprises and international trade policy" sponsored by MUTRAP. The committee is a bridge between enterprise community and governmental negotiation agencies to facilitate the enterprises' consultation on policy formulation, negotiation and implementation of international commitment (Vietnam's WTO Centre, 2013). To achieve these objectives, the committee is composed of representatives from both business associations and government's ministries (on individual capacity). The interaction between enterprises and state actors within the committee seem to result in a success as the decision 60/QD-Ttg recognizing the role of VCCI in the consultation process of trade policy. After this achievement, the committee is now following its 3 initiatives in lobbying decision to join the Vienna Convention on the sale of goods contract (1980 Vienna Convention) and monitoring the participation of Vietnam in the TPP and VN-EU FTA.

The committee has operate its website, providing the update information on the negotiation process, impact study, survey results on the enterprises' opinion on each issue.

In spite of initials achievements, there are still concerns on the operation of the committee:

- There is no evidence on the official provision of information from government to the VCCI. In its various published outputs, the Committee has cited the sources as compiled from overseas, i.e. InsideTrade.

- The committee has uploaded series of enterprises' recommendations to government relating to the negotiation of TPP or VN-EU FTA. These are results of the survey with either enterprises or through other business associations. However, these papers have a tendency to be a summary of survey results with strong recommendations rather than a scientific analysis with balancing of different group benefits. The possible reason might be the lack of permanent involvement of academia in producing these reports. 
In general, the consultation mechanism in Vietnam can be summarized in Table 3. This table proved the strong evidences that Vietnamese government has been making efforts to open the transparence of the country's trade policies to both public and private players.

Table 3.3: Consultation Mechanism in Vietnam

\begin{tabular}{|c|c|c|c|}
\hline Mechanism & Agents & Role & Composition \\
\hline \multirow[t]{3}{*}{$\begin{array}{c}\text { Inter- } \\
\text { department } \\
\text { (Inter- } \\
\text { ministerial) }\end{array}$} & $\begin{array}{l}\text { National } \\
\text { Committee for } \\
\text { International } \\
\text { Economics } \\
\text { Cooperation } \\
\text { (NCIEC) }\end{array}$ & 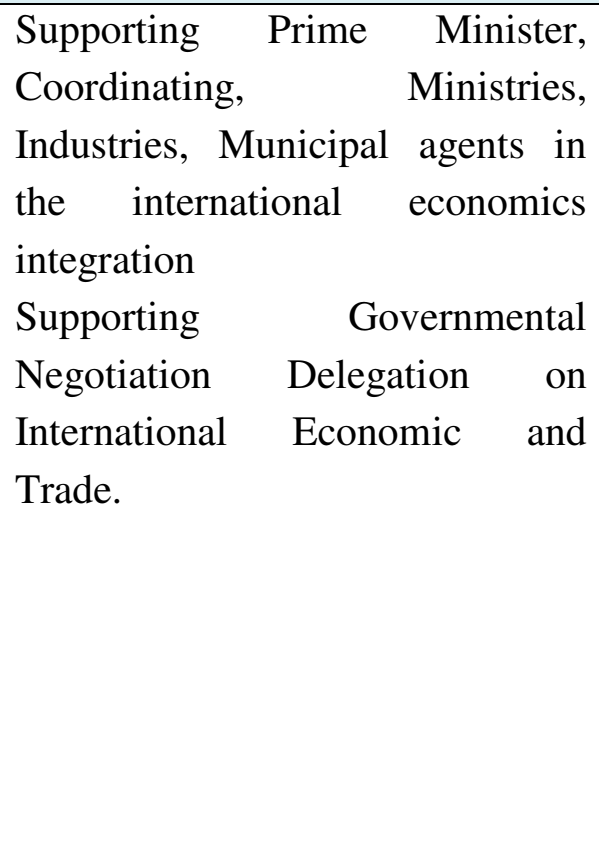 & $\begin{array}{l}\text { Members: Vice Prime } \\
\text { Minister, Minister and } \\
\text { Deputy Minister of } \\
\text { Industrial and } \\
\text { Commerce and other } \\
\text { Deputy Ministers of } \\
\text { other ministries, Vice } \\
\text { Director of National } \\
\text { Bank, Vice Director of } \\
\text { the National Office } \\
\text { Under the direct } \\
\text { supervisor of the Prime } \\
\text { Minister, but de facto, } \\
\text { and belongs to Ministry } \\
\text { of Industry and Trade. }\end{array}$ \\
\hline & $\begin{array}{l}\text { Office of } \\
\text { National } \\
\text { Committee on } \\
\text { International } \\
\text { Economics } \\
\text { Cooperation }\end{array}$ & $\begin{array}{l}\text { Supporting the National } \\
\text { Committee on International } \\
\text { Economics and Cooperation }\end{array}$ & $\begin{array}{l}\text { Belonging to the } \\
\text { Ministry of Industry and } \\
\text { Trade }\end{array}$ \\
\hline & $\begin{array}{l}\text { Governmental } \\
\text { Negotiation } \\
\text { Delegation on } \\
\text { International } \\
\text { Economic and } \\
\text { Trade }\end{array}$ & $\begin{array}{l}\text { Supporting Prime Minister, } \\
\text { Ministry of International Trade } \\
\text { And Industry for international } \\
\text { trade negotiation. } \\
\text { Leading and coordinating } \\
\text { Ministries, relevant government } \\
\text { bodies to set the strategies and } \\
\text { plans, formulation and } \\
\text { implementation for international } \\
\text { trade agreements. }\end{array}$ & $\begin{array}{l}\text { Members: Minister of } \\
\text { Industry and Trade } \\
\text { Ministry, representatives } \\
\text { of departments from } \\
\text { other Ministries. } \\
\text { Under the direct } \\
\text { supervisor of the Prime } \\
\text { Minister }\end{array}$ \\
\hline
\end{tabular}




\begin{tabular}{|c|c|c|c|}
\hline & $\begin{array}{l}\text { NCIEC } \\
\text { (Supported by } \\
\text { the Office of } \\
\text { National } \\
\text { Committee on } \\
\text { International } \\
\text { Economics } \\
\text { Cooperation) }\end{array}$ & $\begin{array}{l}\text { Technical Supporting, Providing } \\
\text { information for the Ministry of } \\
\text { Industry and Trade as well as } \\
\text { other ministries in trade } \\
\text { negotiation, trade policies' } \\
\text { formulation and implementation. }\end{array}$ & \\
\hline \multirow[t]{2}{*}{$\begin{array}{l}\begin{array}{l}\text { Business- } \\
\text { focus } \\
\text { consultatio } \\
\text { n }\end{array} \\
\end{array}$} & $\begin{array}{l}\text { Vietnam } \\
\text { Chamber of } \\
\text { Commerce and } \\
\text { Industry } \\
\text { (VCCI) }\end{array}$ & $\begin{array}{l}\text { Creating forum for the meetings } \\
\text { between private sectors and } \\
\text { public sectors } \\
\text { Supporting public and private } \\
\text { sectors with trade information, } \\
\text { updating negotiation trends in } \\
\text { international trade agreements. } \\
\text { Acting as the third parties in the } \\
\text { consultation from the competent } \\
\text { authorities for business } \\
\text { community on the international } \\
\text { trade negotiation. } \\
\text { Assisting the government bodies } \\
\text { for updating enterprises } \\
\text { information database }\end{array}$ & $\begin{array}{l}\text { Non-government } \\
\text { organization }\end{array}$ \\
\hline & $\begin{array}{l}\text { The } \\
\text { Committee on } \\
\text { International } \\
\text { Trade Policies } \\
\text { (CITP) }\end{array}$ & $\begin{array}{l}\text { Coordinating the forum for the } \\
\text { consultation of international trade } \\
\text { negotiation for business } \\
\text { communities } \\
\text { Being the connection between } \\
\text { competent authorities and } \\
\text { relevant enterprises for the } \\
\text { feasibility study or negotiation of } \\
\text { international trade agreements }\end{array}$ & $\begin{array}{l}\text { Belonging to VCCI } \\
\text { Members: } \\
\text { representatives of } \\
\text { business associations in } \\
\text { crucial industries } \\
\text { experts from competen } \\
\text { authorities such as the } \\
\text { National Assembly, the } \\
\text { International } \\
\text { Cooperation Departmen } \\
\text { of the Vietnamese } \\
\text { Ministries, Office of the } \\
\text { Government and } \\
\text { Universities }\end{array}$ \\
\hline
\end{tabular}




\begin{tabular}{|c|c|c|c|}
\hline & $\begin{array}{l}\text { Vietnamese } \\
\text { Business } \\
\text { Associations }\end{array}$ & $\begin{array}{l}\text { Representatives of individual } \\
\text { enterprises voice on their } \\
\text { proposal of modifications, } \\
\text { suggestions on trade polices } \\
\text { Providing information about } \\
\text { relevant international trade } \\
\text { agreements, trade partners, trade } \\
\text { negotiations... } \\
\text { Visame (Trade } \\
\text { Vietnamese Association of } \\
\text { Medium and Small Enterprises } \\
\text { Setting up } 12 \text { groups of export } \\
\text { oriented entrepreneurs in } 8 \\
\text { provinces to pass the messages } \\
\text { and suggestions from small and } \\
\text { medium enterprises (Dordi.C, } \\
\text { 2012) } \\
\text { Offering trade counseling } \\
\text { services to their member }\end{array}$ & $\begin{array}{l}\text { (i.e Lefaso, Vinasme, } \\
\text { VICOFA, VINASA, } \\
\text { VIETFOREST ; } \\
\text { VITAS...) }\end{array}$ \\
\hline & $\begin{array}{l}\text { Enterprises } \\
\text { Representative } \\
\text { s of enterprises }\end{array}$ & $\begin{array}{l}\text { Debating and commenting on the } \\
\text { feasibility study or the negotiation } \\
\text { of the international trade } \\
\text { agreements on the time schedule } \\
\text { provide by competent authorities } \\
\text { (i.e: suggestions on strategies, } \\
\text { requirements for trade partners or } \\
\text { ideas for the negotiation process) }\end{array}$ & \\
\hline $\begin{array}{l}\text { Multi-stake } \\
\text { holders }\end{array}$ & $\begin{array}{l}\text { NGOs (i.e } \\
\text { EuroCham, } \\
\text { AusCham, } \\
\text { Academia) } \\
\text { (do not directly } \\
\text { participate, } \\
\text { only support } \\
\text { the enterprises) }\end{array}$ & $\begin{array}{l}\text { Assisting, representing the } \\
\text { Foreign and Vietnamese } \\
\text { enterprises in international Trade } \\
\text { agreements } \\
\text { Collecting information, providing } \\
\text { information for those business } \\
\text { communities } \\
\text { Technical supports toVietnamese } \\
\text { government bodies in trade } \\
\text { policies' making process, } \\
\text { assisting enterprises, business } \\
\text { association with lobby activities. }\end{array}$ & \\
\hline
\end{tabular}




\begin{tabular}{|l|l|l|l|}
\hline $\begin{array}{l}\text { Academia } \\
\text { (research and } \\
\text { training } \\
\text { institutions) }\end{array}$ & $\begin{array}{l}\text { Conducting research projects by } \\
\text { the request and funded by } \\
\text { governemnt. }\end{array}$ & $\begin{array}{l}\text { State-owned institution } \\
\text { Independent ínstitution } \\
\text { Providing information to society } \\
\text { through conference and journals. }\end{array}$ & \\
\hline
\end{tabular}

Source: Information is collected and summarized from the Legal documents: Decision No.182/2007/QĐTTg, Decision No.06/2012/QD-TTg, and websites: http://wtocenter.vn/citp, http://moit.vecita.gov.vn/

In conclusion, similar to the case of African countries studied by Kaukab. R et al (2009), the inter-department, business-focus consultation in Vietnam are arranged separately with the multistakeholders consultation. And it is obvious that non-state actors can formally react in the process via emails and comments on the competent authorities' websites or indirectly via the agents like business or industry associations, VCCI or CITP. They are provided information but are not allowed to participate in the negotiation of the international trade agreements with the trade partners. Are these lobby instruments really efficient in improving the non-states participation in the consultation process or enhance their influence sphere on the policy makers? The answer would be further considered in the statistics analysis. 


\section{CHAPTER 4: EMPIRICAL STUDIES}

\subsection{Overview of the survey}

\subsubsection{Methodology}

Apart from secondary data, the research focuses on analyzing the statistical result of primary data collected through surveys with enterprises and interviews with governmental officials and representatives of associations. The surveyed objects are selected randomly given their variety in business types, scale and funding resources.

Questionnaires were designed to provide information on reasons, methods and frequency of consultation in trade policy making. There are 3 different types of questionnaire, corresponding to enterprises, government officials and associations. A pre-test has also been used to assure questionnaires' validity and accuracy. Questionnaires are attached in the Annex 1 of the report. Due to limited resources, convenient sampling was applied. The questionnaires were posted on $\underline{w w w . s u r v e y m o n k e y . c o m}$ with a separate email sent to each potential recipient.

\subsubsection{Proportion of survey recipients}

The research group received quite a lot of feedbacks from different stakeholders, including the government officials, associations, and enterprises. A large number of enterprises were targeted by the research group due to the complex nature of this type of non-state actors: Enterprises are often the group most heavily affected by any changes in the trade policies, and often are the one organizing the most lobbying activities all over the world. The table below reflects the proportion of groups of non-state actors participated in the survey.

Table 4.1. The proportion of surveyed recipients

\begin{tabular}{|l|l|c|c|}
\hline Actors & By groups & Number & $\begin{array}{l}\text { Proportion } \\
(\boldsymbol{\%})\end{array}$ \\
\hline $\begin{array}{l}\text { Government } \\
\text { officials }\end{array}$ & Total & $\mathbf{1 6}$ & $\mathbf{1 0 0 \%}$ \\
\hline & MoIT & 9 & $56 \%$ \\
\cline { 2 - 4 } & Other ministries & 7 & $44 \%$ \\
\hline Associations & Total & $\mathbf{3}$ & $\mathbf{1 0 0 \%}$ \\
\hline Enterprises & Total & $\mathbf{2 2 6}$ & $\mathbf{1 0 0 \%}$ \\
\hline
\end{tabular}




\begin{tabular}{|l|l|c|c|}
\hline $\begin{array}{l}\text { By } \begin{array}{l}\text { Beadquarters } \\
\text { hecation }\end{array} \\
\text { locth of Vietnam }\end{array}$ & 190 & $84 \%$ \\
\cline { 2 - 4 } $\begin{array}{l}\text { By state- } \\
\text { owned capital }\end{array}$ & With state-owned capital & 36 & $16 \%$ \\
\cline { 2 - 4 } $\begin{array}{l}\text { By Foreign } \\
\text { direct }\end{array}$ & Without state-owned capital foreign direct investment & 48 & $21 \%$ \\
\cline { 2 - 4 } investment & Without foreign direct investment & 171 & $78 \%$ \\
\hline
\end{tabular}

The research group divided the surveyed enterprises into different groups based on the ownership and the location of the headquarters.

\subsection{Analysis and findings}

\subsubsection{Why do actors participate in the trade policy consultation process?}

\subsubsection{From the Government's perspective}

Table 4.2 summaries the reasons why the Vietnam's government asks for consultation from nonstate actors in trade policy process. There are 6 possible reasons including: satisfying legal requirement and international commitments, assuring policy transparency, gauging social consensus, receiving real information, assuring efficient policy application and supporting advance enterprise preparation. These six possible reasons were divided into two groups, i.e. to satisfy legal requirement and to enhance policy quality respectively.

Table 4.2. Reasons for government to carry out consultation in trade policy process

\begin{tabular}{|l|l|l|}
\hline & Reasons & $\begin{array}{l}\text { Percentage } \\
\text { agreement }\end{array}$ \\
\hline \multirow{2}{*}{$\begin{array}{c}\text { To satisfy legal } \\
\text { requirement }\end{array}$} & To satisfy international commitment & $44 \%$ \\
\cline { 2 - 3 } $\begin{array}{l}\text { To enhance policy } \\
\text { quality }\end{array}$ & To assure policy transparency & $94 \%$ \\
\cline { 2 - 3 } & To create societal consensus & $56 \%$ \\
\cline { 2 - 3 } & \begin{tabular}{l} 
To assure efficient application \\
\cline { 2 - 3 }
\end{tabular} & $\begin{array}{l}\text { To support beforehand preparation of } \\
\text { enterprises }\end{array}$ \\
\hline
\end{tabular}

Source: Survey Results of the Research Team (2013) 
The key finding of this study is that the involvement and participation of non-state actors in the formulation and implementation of trade policies in Vietnam is to improve trade policy quality. Table 4.2 shows that the second group receives more agreement than the first one. It implies that, government officials consider non-state actors engagements as "should do" activities rather than "forced to do". There are some reasons for this. First, currently, policy implementation proves to be inefficient due to the lack of social consensus and enterprises' preparation. Second, ministries responsible for trade policy-making and implementation faced constraints related to their capacity and adequate information. For example, in antidumping cases, due to difference in collecting statistic and facts, the government could not receive the real figures on export revenue if enterprises do not cooperate and provide them with their data. It's advisable for the government to cooperate with non-state actors.

From the result above, it is obvious that for the government, assuring policy transparency is the most important reason for non-state engagement (94\%). The state actors recognize transparency as a key element in the negotiation process and outcomes in Vietnam. Especially, after Viet Nam became a WTO's member, the requirements to enhance transparency and legitimacy in trade policy decision-making have been more and more reflected in debates on the openness of the multilateral negotiations.

The government officers identified supporting beforehand preparation of enterprises and assuring efficient application as the second and the third important reasons for consultation with non-state actors in trade policy-making (75\% and 63\% respectively). Besides, gauging social consensus and receiving real information are also considered as the fourth important factors for engagement of non-state actors (both 56\%). Surprisingly, satisfying legal requirement and international commitment was ranked the least important reason by the government (44\%), implying that nonstate actors are yet to be fully accepted and appreciated as partners in trade policy-making process even the government has issued the legal regulations allowing and encouraging non-state actors to participate into trade negotiations.

Further interviews with governmental officials disclosed that they are all aware of the benefits of consulting enterprises. However, in the context of globalization, the nested interest groups will result in different, or even opposing opinions in consultation of any trade policy. Given their limited time and capacity, they cannot solve the conflicts of interest.. So, in their views, consultation is sometimes organized de jure to satisfy legal requirement.

\subsubsection{From non - state actors' perspective}


On the other side, among three main reasons for trade policy's involvement, non-state actors mostly considered that the consultation would be for their own benefits because they will be affected by the policy (73\%). Some of them seemed to be aware of the existence of winner and losers from policy. Surprisingly, 22\% respondents agreed that consultation is to provide real information to the government. It coincides with the assumption that enterprises just do what is beneficial for them. Consequently, the information provided will likely be biased toward business benefits rather than society's benefits. In other words, the direct consultation from enterprises in Vietnam will be inevitably avoided from these nested interest groups.

Table 4.3. Reasons for non-state actors to participate into trade policy process (by location)

\begin{tabular}{|c|c|c|c|c|}
\hline \multirow[t]{2}{*}{ Reasons } & \multirow[t]{2}{*}{ Percentage } & \multicolumn{2}{|c|}{$\begin{array}{l}\text { Percentage by } \\
\text { location }\end{array}$} & \multirow[t]{2}{*}{ Difference } \\
\hline & & $\begin{array}{l}\text { The } \\
\text { North }\end{array}$ & $\begin{array}{l}\text { The } \\
\text { South }\end{array}$ & \\
\hline $\begin{array}{l}\text { Providing the government agencies with real } \\
\text { information }\end{array}$ & $22 \%$ & $17 \%$ & $22 \%$ & 0.053 \\
\hline $\begin{array}{l}\text { Receiving adequate beneficial policy for their } \\
\text { own enterprises }\end{array}$ & $73 \%$ & $62 \%$ & $44 \%$ & $-0.171 *$ \\
\hline $\begin{array}{l}\text { For general benefits for all industries and } \\
\text { society }\end{array}$ & $51 \%$ & $43 \%$ & $33 \%$ & -0.098 \\
\hline
\end{tabular}

Source: Survey Results of the Research Team (2013)

Note: *, **, *** denote for significant level at 1\%, 5\% and $10 \%$

For the first and the third reasons (see Table 4.3), no evidence shows that there is difference among enterprises' choice, including the Northern and the Southern ones and among their ownership.

Concerning the second reason, enterprises' opinion varies between Southern and Northern ones, and differs among their ownership. The proportion of Northern enterprises agreeing with this reason is significantly higher than the Southern's (62\% and $44 \%$ respectively). It is interesting as in Vietnam, enterprises in the South are comparatively more business oriented and dynamic, which should lead to more active participation in consultation process. The possible reasons is that they anticipate the poorly efficient process, leading to the "just do the business" rather than "try to change policy" attitude. In other words, they tend to accept all possibility from policy changes. 
Table 4.4. Reasons for non-state actors to participate into trade policy process (divided by their ownership)

\begin{tabular}{|l|c|c|c|c|c|c|}
\hline \multirow{2}{*}{ Reasons } & \multicolumn{3}{|l|}{$\begin{array}{l}\text { Between State and Non- } \\
\text { state enterprises }\end{array}$} & \multicolumn{3}{l|}{$\begin{array}{l}\text { Between FDI and Non-FDI } \\
\text { enterprises }\end{array}$} \\
\cline { 2 - 8 } & $\begin{array}{l}\text { State } \\
\text { one }\end{array}$ & $\begin{array}{l}\text { Non- } \\
\text { state one }\end{array}$ & $\begin{array}{l}\text { Differ } \\
\text { ence }\end{array}$ & FDI one & $\begin{array}{l}\text { Non- } \\
\text { FDI one }\end{array}$ & $\begin{array}{l}\text { Differen } \\
\text { ce }\end{array}$ \\
\hline $\begin{array}{l}\text { Providing the government } \\
\text { agencies with real information }\end{array}$ & $25 \%$ & $16 \%$ & $9 \%$ & $18 \%$ & $17 \%$ & 0.009 \\
\hline $\begin{array}{l}\text { Receiving adequate beneficial } \\
\text { policy for their own enterprises }\end{array}$ & $48 \%$ & $70 \%$ & $0.222 *$ & $64 \%$ & $51 \%$ & $0.127^{*}$ \\
\hline $\begin{array}{l}\text { For general benefits for all } \\
\text { industries and society }\end{array}$ & $50 \%$ & $40 \%$ & 0.096 & $43 \%$ & $42 \%$ & 0.011 \\
\hline
\end{tabular}

Source: Survey Results (2013)

Note: $*, * *, * * *$ denote for significant level at $1 \%, 5 \%$ and $10 \%$

Relating to the presence of state capital among the domestic companies, the non-state enterprises more accept this second reason than the state ones (70\% and $48 \%$ respectively). It might be the evidence that state-owned enterprises are less interested in policy consultation with the assumption that the government should protect the benefits of their state-owned enterprises.

As for FDI and non-FDI enterprises, 64\% of the FDI ones agree that trade policy consultation is good for their own, and 51\% of non-FDI companies approve for this choice (See Table 4.4). That implies that the non-state and FDI enterprises seem more pragmatic because they feel less safe and less protective from the government than the state ones in the economy.

Comparing the reasons from both sides, it seems to be a mismatch between the states and the enterprises. From the state's side, they see consultations mostly a way to improve policy transparency, which is understood by government officials as one-way flow of information from the state to the non-state actors. So they try to publicise the information to the public to fulfill this one-way flow of information. From the enterprises' perspective, consultation needs to provide benefits to them, which cannot be satisfied with one-way communication without government's responses to business's comments.

\subsubsection{Who are involved in the trade policy formulation?}

Among non-state actors, only associations have frequently participated in trade policy formulation through their relations with government actors. This can be explained by the fact 
that many associations' staff and leaders are former governmental officials. Their personal relationships have allowed them to affect trade policy, either formally or informally.

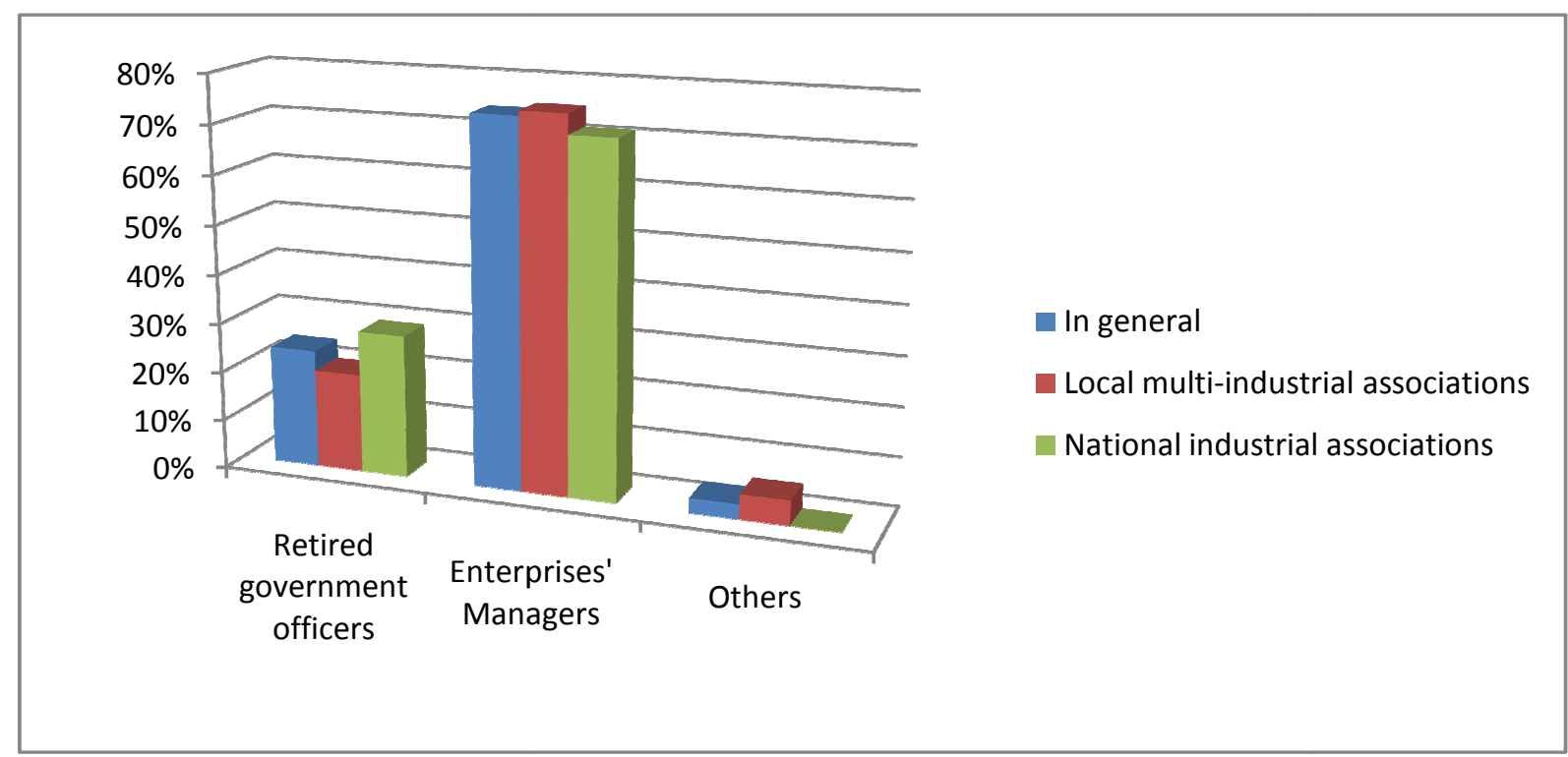

Figures 4.1. Managers in Vietnam Industry/Business Associations

Source: Report on Vietnam Business/Industry Associations' capacity, VCCI (2013), p.30

The other actors such as enterprises and academia have much less contacts. While enterprises can indirectly involve in the process, academia actors has direct but less frequent roles in trade policy formulation.

Table 4.5. Actors involving in trade policy formulation in Vietnam with frequency

\begin{tabular}{|l|l|l|}
\hline 1 & Ministries to Enterprises & $\begin{array}{l}67 \% \text { of responded governmental officials has consulted } \\
\text { enterprises }\end{array}$ \\
\hline & Enterprises to ministries & $\begin{array}{l}29 \% \text { responded enterprises has commented on draft of } \\
\text { trade policy } \\
52 \% \text { responded enterprises has participated in conferences } \\
\text { organised by government }\end{array}$ \\
\hline 2 & Ministries to Associations & $\begin{array}{l}100 \% \text { of responded governmental officials has consulted } \\
\text { associations }\end{array}$ \\
\hline 3 & Associations to Ministries & $\begin{array}{l}100 \% \text { of responded association representatives has } \\
\text { contacted with ministries }\end{array}$ \\
\hline Ministries to Academia & $\begin{array}{l}33 \% \text { of responded governmental officials has usually } \\
\text { consulted academia actors } \\
67 \% \text { of responded governmental officials has occasionally } \\
\text { consulted individual researchers }\end{array}$ \\
\hline
\end{tabular}




\begin{tabular}{|l|l|l|}
\hline 4 & $\begin{array}{l}\text { Ministries to Governmental } \\
\text { institute }\end{array}$ & $\begin{array}{l}50 \% \text { of responded governmental officials has consulted } \\
\text { governmental institutes }\end{array}$ \\
\hline 5 & Enterprises to Association & $\begin{array}{l}44 \% \text { responded enterprises has send their opinions } \\
\text { through associations }\end{array}$ \\
\hline
\end{tabular}

Source: Survey Results (2013)

In general, we see the consultation process seem to be based more on personal relationships. As mentioned above, there are movement of people among government officials to associations (as president of association after retired), state-owned enterprises (representatives of state capital contribution), government research institutes. Those actors are also more active in consultation process, creating core area of trade policy consultation in Vietnam.

As for the government, the internal consultation with other relevant ministries and within departments of the ministries seem to be most used (3.4 point and 3.1 point at ranking scale) as $56 \%$ and $37.5 \%$ of government officials say that they always consult with other relevant ministries and within the ministries during trade policy - making process respectively. This result is similar to other countries, including developing and also developed countries, as the nature of trade policy has become more and more complicated, requiring the involvement of different departments and ministries. In addition to this internal policy consultation, all the other actors are consulted less frequently, especially independent research/university and enterprise as can be seen from the below table.

Table 4.6. The frequency of consultation with other partners in trade policy process

\begin{tabular}{|l|r|}
\hline Actors & Average \\
\hline Other department within the ministry & 3.1 \\
\hline Other relevant ministries & 3.4 \\
\hline Governmental institute & 2.6 \\
\hline Institute and university & 2.3 \\
\hline Association & 2.9 \\
\hline Enterprise & 2.5 \\
\hline Individuals, experts and researchers & 2.5 \\
\hline
\end{tabular}

Source: Survey Results of the Research Team (2013)

Note: $*, * *, * * *$ denote for significant level at $1 \%, 5 \%$ and $10 \%$

Average level $1 \rightarrow 2 \rightarrow 3 \rightarrow 4$ denote for occasionally $\rightarrow$ Sometimes $\rightarrow$ Usually $\rightarrow$ Always

Besides, the government usually pays attention to associations when they need consultation (2.9 point). Nevertheless, conforming to Hoang Van Chau (2009), further interview says that 
association has not played its important role as enterprises' representatives. The government also occasionally consults with individual experts, enterprise, and academic institute (2.6, 2.5 and 2.5 point respectively). It implies that mechanism for consultation is not open to non-state actors, especially enterprises and academia. It means that the enterprises will have few opportunities to interact directly to the government in trade policy - making process.

Table 4.7 shows different target groups including in governmental officials, legislators as policy makers and ministerial officers as policy negotiators for the enterprises' advocacies

Table 4.7. The enterprises' targets of advocacies

\begin{tabular}{|c|c|c|c|c|c|c|c|c|c|c|}
\hline \multirow[b]{2}{*}{$\begin{array}{l}\text { Targets of } \\
\text { advocacy }\end{array}$} & \multirow[b]{2}{*}{$\begin{array}{l}\text { Avera } \\
\text { ge }\end{array}$} & \multicolumn{3}{|c|}{ By Headquarter } & \multicolumn{3}{|c|}{$\begin{array}{l}\text { Between State and } \\
\text { Non-state enterprises }\end{array}$} & \multicolumn{3}{|c|}{$\begin{array}{l}\text { Between FDI and } \\
\text { Non-FDI } \\
\text { enterprises }\end{array}$} \\
\hline & & $\begin{array}{l}\text { The } \\
\text { Sout } \\
\text { h }\end{array}$ & \begin{tabular}{|l|} 
The \\
Nort \\
h \\
\end{tabular} & $\begin{array}{l}\text { Differen } \\
\text { ce }\end{array}$ & $\begin{array}{l}\text { No } \\
\text { n- } \\
\text { stat } \\
\text { e }\end{array}$ & $\begin{array}{l}\text { Stat } \\
\text { e }\end{array}$ & $\begin{array}{l}\text { Differen } \\
\text { ce }\end{array}$ & $\begin{array}{l}\text { No } \\
\text { n- } \\
\text { FDI }\end{array}$ & $\begin{array}{l}\text { FD } \\
\text { I }\end{array}$ & $\begin{array}{l}\text { Differen } \\
\text { ce }\end{array}$ \\
\hline $\begin{array}{l}\text { Directly } \\
\text { make } \\
\text { suggestion } \\
\text { to the } \\
\text { Governmen } \\
\mathrm{t} \\
\text { (governmen } \\
\text { tal } \\
\text { institutions } \\
\text { and } \\
\text { officials) }\end{array}$ & 2.2 & 2.5 & 2.0 & $0.495^{*}$ & 2.6 & 1.9 & $0.710^{*}$ & 2.1 & 2.2 & -0.115 \\
\hline $\begin{array}{l}\text { Directly } \\
\text { make } \\
\text { suggestion } \\
\text { to the } \\
\text { National } \\
\text { Assembly } \\
\text { (legislators) }\end{array}$ & 2.2 & 2.8 & 2.0 & $0.754^{*}$ & 2.4 & 2.0 & $0.404 *$ & 2.1 & 2.2 & -0.093 \\
\hline $\begin{array}{l}\text { Make } \\
\text { suggestion } \\
\text { to the }\end{array}$ & 2.8 & 3.1 & 2.7 & 0.368 & 3.0 & 2.7 & 0.288 & 2.8 & 2.9 & -0.093 \\
\hline
\end{tabular}




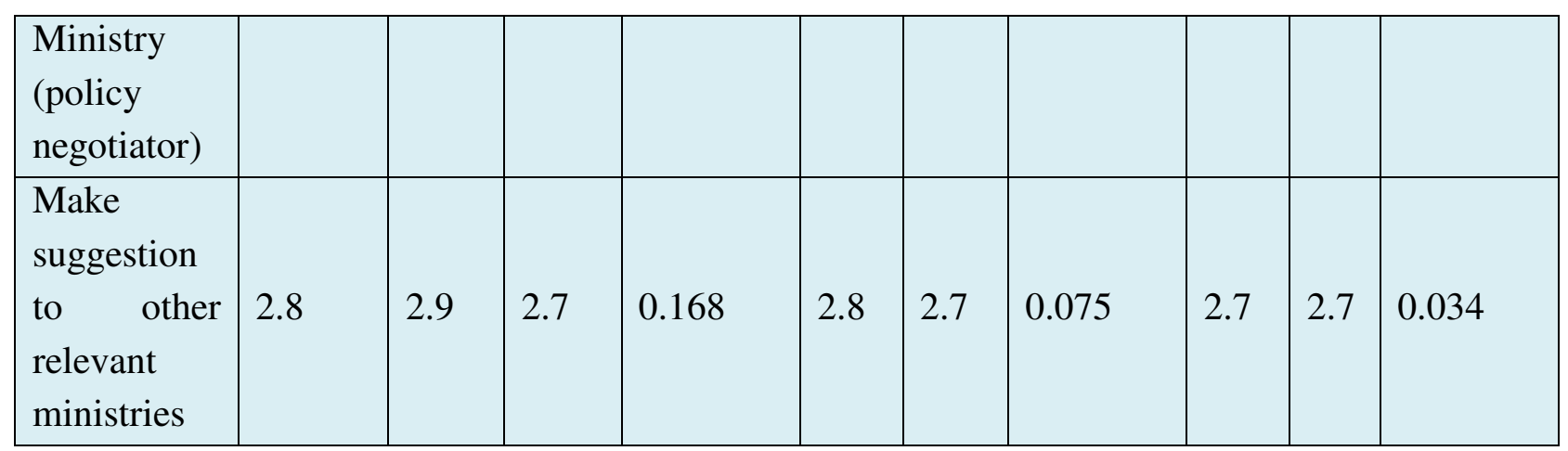

Source: Survey Results of the Research Team (2013)

Note: *, **, *** denote for significant level at $1 \%, 5 \%$ and $10 \%$

Average level $1 \rightarrow 2 \rightarrow 3 \rightarrow 4$ denote for unnecessary $\rightarrow$ Necessity but Unimportant $\rightarrow$ Important $\rightarrow$ Very Important level

Table 4.7 shows that enterprises all consider policy negotiator at the Ministries as the most important target for their policy advocacy (2.8 point out of 4 at average level). Moreover, statistical tests show that there is no significant difference by headquarter ownership on their consideration. It implies that advocacy efforts are also targeted at lower level officials within ministries. This could be explained for many reasons. As for the enterprises, negotiators at ministerial level seem to have far better knowledge on the details and substances of the country's trade policy, and easier to get in tough. Therefore, promoting relationships with officials from ministries could allow more space and opportunities to deliver their advocacy messages via these state actors.

In addition, there is evidence that enterprises in the South and non-state business target at higher levels (National Assembly) than the ones in the North and state business (ministerial officials). Once again, the possible reason might be personal relationship as all ministries are located in Hanoi, so the personal interaction seems to be comparatively higher. In the South, or for nonstate enterprise, it is difficult to directly discuss with lower officials at executive level, then they see legislators at National Assembly as the necessary and important target.

\subsubsection{How do actors involve in the trade policy making process in term of methods and content of consultation?}

\subsubsection{Method of consultations}

For the enterprises, there are several ways to seek to influence trade policy. These include participation through Vietnam Chamber of Commerce and Industry (VCCI), business associations, academic institutes \& universities, public media channels, seminars \& conferences, 
and self-initiate interaction with the Government. Table 4.8 summarizes ways used by enterprises to influence trade policy and the relative importance (average level) attached to each alternative by enterprises.

Table 4.8. Ways of enterprise's engagement into trade policy on participation's methods

\begin{tabular}{|c|c|c|c|c|c|c|c|c|c|c|}
\hline \multirow[b]{2}{*}{ Reasons } & \multirow[b]{2}{*}{$\begin{array}{l}\text { Avera } \\
\text { ge }\end{array}$} & \multicolumn{3}{|c|}{ By Headquarter } & \multicolumn{3}{|c|}{$\begin{array}{l}\text { Between State and } \\
\text { Non-state enterprises }\end{array}$} & \multicolumn{3}{|c|}{$\begin{array}{l}\text { Between FDI and } \\
\text { Non-FDI enterprises }\end{array}$} \\
\hline & & $\begin{array}{l}\text { The } \\
\text { Sout } \\
\text { h }\end{array}$ & $\begin{array}{l}\text { The } \\
\text { Nort } \\
\text { h }\end{array}$ & $\begin{array}{l}\text { Differen } \\
\text { ce }\end{array}$ & $\begin{array}{l}\text { Non } \\
- \\
\text { stat } \\
\text { e }\end{array}$ & $\begin{array}{l}\text { Stat } \\
\text { e }\end{array}$ & $\begin{array}{l}\text { Differen } \\
\text { ce }\end{array}$ & $\begin{array}{l}\text { Non } \\
- \\
\text { FDI }\end{array}$ & $\begin{array}{l}\text { FD } \\
\text { I }\end{array}$ & $\begin{array}{l}\text { Differen } \\
\text { ce }\end{array}$ \\
\hline $\begin{array}{l}\text { Through } \\
\text { Vietnam } \\
\text { chamber } \\
\text { of } \\
\text { Commerc } \\
\text { e and } \\
\text { Industry } \\
\text { (VCCI) }\end{array}$ & 2.5 & 3 & 2.4 & $0.571 *$ & 2.3 & 2.5 & -0.222 & 2.4 & 2.6 & -0.198 \\
\hline $\begin{array}{l}\text { Through } \\
\text { Associatio } \\
\text { ns }\end{array}$ & 2.6 & 3.0 & 2.6 & $0.432 *$ & 2.5 & 2.6 & -0.037 & 2.6 & 2.9 & -0.330 \\
\hline $\begin{array}{l}\text { Through } \\
\text { academia } \\
\text { institutes } \\
\& \\
\text { universitie } \\
\text { s }\end{array}$ & 2.0 & 2.5 & 1.9 & $0.622 *$ & 2.1 & 2.0 & 0.104 & 2.0 & 2.0 & 0.003 \\
\hline $\begin{array}{l}\text { Through } \\
\text { public } \\
\text { media } \\
\text { channels }\end{array}$ & 2.7 & 3.0 & 2.6 & $0.409^{*}$ & 2.5 & 2.7 & -0.291 & 2.7 & 2.7 & 0.005 \\
\hline $\begin{array}{l}\text { Through } \\
\text { seminars, } \\
\text { conferenc } \\
\text { e }\end{array}$ & 2.8 & 3.2 & 2.7 & $0.514^{*}$ & 2.7 & 2.8 & -0.134 & 2.8 & 2.7 & 0.088 \\
\hline $\begin{array}{l}\text { Self- } \\
\text { initiated }\end{array}$ & 2.5 & 3 & 2.3 & $0.616^{*}$ & 2.8 & 2.3 & $0.541 *$ & 2.4 & 2.6 & -0.210 \\
\hline
\end{tabular}




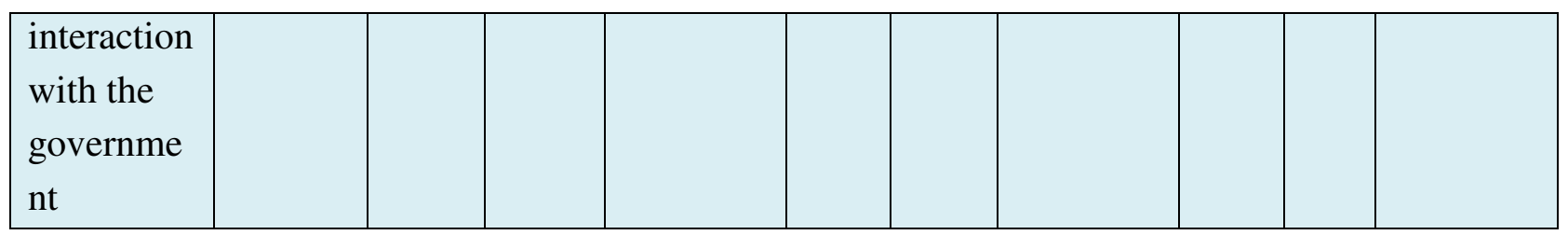

Source: Survey Results of the Research Team (2013)

Note: *, **, *** denote for significant level at 1\%, 5\% and $10 \%$

Average level $1 \rightarrow 2 \rightarrow 3 \rightarrow 4$ denote for unnecessary $\rightarrow$ Necessity but Unimportant $\rightarrow$ Important $\rightarrow$ Very Important level

The surveyed enterprises prefer to send their opinion and participate in conferences/seminars and public media. They rank these channels as the first and the second important ways to influence the policy with 2.8 and 2.7 out of 4 points in average level respectively. It's due to they think it can help to reach the government easier and get feedback faster. Besides, the responded enterprises consider associations as the third important approach to deliver their message and participate into trade policy process ( 2.6 out of 4 points at average level).

There is difference between the Northern and the Southern enterprises' consideration in all policy's involvement approaches. In each choice, the Southern companies always more agree with the importance of each way than the Northern ones. As the business environment in the South are more dynamic, enterprises here are also given more importance to the consultation process in trade policy formulation.

As for the Government, in consistent with the reason, state actors use different methods of consultation. The most frequent method is official letter sent to other ministries and association (not for enterprises). This is problematic and cannot assure an effective understanding and result because this method is indirect and one-way interaction. Besides, enterprises usually organize conferences or seminars to get information from others for consultation (See Table 10), which also is considered as the most important approach for trade policy's involvement by the enterprises. As a result, participation of the business community in conferences/seminars and in associations seems to be common channels for two way communication between the State and the business community.

Table 4.9. The government's ways to ask for consultation from non-state actors

\begin{tabular}{|l|l|}
\hline Methods & Average \\
\hline Sending official letter requesting information & $\mathbf{2 . 9}$ \\
\hline Sending questionnaires requesting information & $\mathbf{2 . 5}$ \\
\hline Posting questionnaire on their website & $\mathbf{2}$ \\
\hline Organizing conference for information & $\mathbf{2 . 8}$ \\
\hline
\end{tabular}




\begin{tabular}{|l|l|}
\hline exchange & \\
\hline Publicizing draft on website & $\mathbf{2 . 4}$ \\
\hline Ordering research & $\mathbf{2 . 2}$ \\
\hline
\end{tabular}

Source: Survey Results of the Research Team (2013)

Note: Average level from $1 \rightarrow 2 \rightarrow 3 \rightarrow 4$ denote for necessity level of none $\rightarrow$ occasionally $\rightarrow$ Usually $\rightarrow$ Always

Table 4.9 also shows that there is no direct attempt from the state to interact with the enterprises even they consider this as necessary way. Therefore, the current methods of consultation are not efficient enough to assure two-way communication between the Government and the enterprises because organizing conferences/seminars still depends on the State's willingness, so the business is in a passive position to involve in the policy making process. Besides, the association as a current common channel has not played an important role on behalf of their representatives to deliver ideas and policy's advocacy.

\subsubsection{Content of consultation}

Table 12 shows enterprises' good understanding about trade policies. They are almost able to evaluate the impact of trade policy. $87 \%$ of responses say that they are able to analyze the direct effects from the trade policies to its activities. Besides, about $79 \%$ of surveyed enterprises acknowledge that they can analyze the effects from the trade policies to related industries, which may influence its activities. As for overall effects on trade policy, only 59\% of surveyed enterprises see their ability to evaluate the impact

Table 4.10. Enterprises' capability about trade policies

\begin{tabular}{|c|c|c|c|c|c|c|c|c|c|c|}
\hline \multirow{2}{*}{$\begin{array}{l}\text { Enterprises' } \\
\text { Understanding }\end{array}$} & \multirow[b]{2}{*}{$\begin{array}{l}\text { Perce } \\
\text { ntage }\end{array}$} & \multicolumn{3}{|c|}{ By Headquarter } & \multicolumn{3}{|c|}{$\begin{array}{l}\text { Between State } \\
\text { and Non-state } \\
\text { enterprises }\end{array}$} & \multicolumn{3}{|c|}{$\begin{array}{l}\text { Between FDI } \\
\text { and Non-FDI } \\
\text { enterprises }\end{array}$} \\
\hline & & $\begin{array}{l}\text { The } \\
\text { Sout } \\
\text { h }\end{array}$ & $\begin{array}{l}\text { The } \\
\text { Nort } \\
\text { h }\end{array}$ & $\begin{array}{l}\text { Differen } \\
\text { ce }\end{array}$ & $\begin{array}{l}\text { Non } \\
- \\
\text { state }\end{array}$ & $\begin{array}{l}\text { Stat } \\
\text { e }\end{array}$ & $\begin{array}{l}\text { Diff } \\
\text { eren } \\
\text { ce }\end{array}$ & $\begin{array}{l}\text { No } \\
\text { n- } \\
\text { FDI }\end{array}$ & FDI & $\begin{array}{l}\text { Diffe } \\
\text { renc } \\
\text { e }\end{array}$ \\
\hline $\begin{array}{l}\text { The enterprise } \\
\text { only can figure } \\
\text { out (without } \\
\text { analysis) the } \\
\text { possible effects } \\
\text { from the trade } \\
\text { policies }\end{array}$ & $64 \%$ & $42 \%$ & $45 \%$ & -0.035 & $40 \%$ & $\begin{array}{l}48 \\
\%\end{array}$ & $\begin{array}{l}0.08 \\
6\end{array}$ & $\begin{array}{l}46 \\
\%\end{array}$ & $\begin{array}{l}48 \\
\%\end{array}$ & $\begin{array}{l}0.01 \\
6\end{array}$ \\
\hline
\end{tabular}




\begin{tabular}{|c|c|c|c|c|c|c|c|c|c|c|}
\hline $\begin{array}{l}\text { The enterprise is } \\
\text { able to analyze the } \\
\text { direct effects from } \\
\text { the trade policies } \\
\text { to its activities }\end{array}$ & $87 \%$ & $39 \%$ & $67 \%$ & $-0.279 *$ & $71 \%$ & $\begin{array}{l}63 \\
\%\end{array}$ & $\begin{array}{l}0.07 \\
6\end{array}$ & $\begin{array}{l}65 \\
\%\end{array}$ & $\begin{array}{l}61 \\
\%\end{array}$ & $\begin{array}{l}0.04 \\
0\end{array}$ \\
\hline $\begin{array}{l}\text { The enterprise is } \\
\text { able to analyze the } \\
\text { effects from the } \\
\text { trade policies to } \\
\text { related industries, } \\
\text { which may } \\
\text { influence its } \\
\text { activities. }\end{array}$ & $79 \%$ & $47 \%$ & $58 \%$ & -0.106 & $58 \%$ & $\begin{array}{l}58 \\
\%\end{array}$ & $\begin{array}{l}0.00 \\
4\end{array}$ & $\begin{array}{l}58 \\
\%\end{array}$ & $\begin{array}{l}58 \\
\%\end{array}$ & $\begin{array}{l}0.00 \\
1\end{array}$ \\
\hline $\begin{array}{l}\text { The enterprise is } \\
\text { able to analyze the } \\
\text { overall effects of } \\
\text { the trade policies. }\end{array}$ & $59 \%$ & $36 \%$ & $42 \%$ & -0.054 & $44 \%$ & $\begin{array}{l}43 \\
\%\end{array}$ & $\begin{array}{l}0.00 \\
7\end{array}$ & $\begin{array}{l}43 \\
\%\end{array}$ & $\begin{array}{l}39 \\
\%\end{array}$ & $\begin{array}{l}0.04 \\
6\end{array}$ \\
\hline
\end{tabular}

\section{Source: Survey Results of the Research Team (2013)}

Note: $*, * *, * * *$ denote for significant level at $1 \%, 5 \%$ and $10 \%$

Statistical tests have not disclosed any significant difference by locations as well as state/FDI capital presence, except in the capacity for analyzing direct policy impacts between South and North enterprises. Regarding this aspect, enterprises in the North seems to be better. It can be explained the assumption that the North is more "academic" than the South through interacting with academic sector, which is mostly located in the North.

Table 4.11. The enterprises' attitude as the policy affects negatively their activities

\begin{tabular}{|c|c|c|c|c|c|c|c|c|c|c|}
\hline \multirow[b]{2}{*}{$\begin{array}{l}\text { The enterprises' } \\
\text { attitude }\end{array}$} & \multirow[b]{2}{*}{$\begin{array}{l}\text { Perce } \\
\text { ntage }\end{array}$} & \multicolumn{3}{|c|}{ By Headquarter } & \multicolumn{3}{|c|}{$\begin{array}{l}\text { Between State and } \\
\text { Non-state } \\
\text { enterprises }\end{array}$} & \multicolumn{3}{|c|}{$\begin{array}{l}\text { Between FDI and } \\
\text { Non-FDI } \\
\text { enterprises }\end{array}$} \\
\hline & & $\begin{array}{l}\text { The } \\
\text { Sout } \\
\text { h }\end{array}$ & $\begin{array}{l}\text { The } \\
\text { Nort } \\
\text { h }\end{array}$ & $\begin{array}{l}\text { Differe } \\
\text { nce }\end{array}$ & $\begin{array}{l}\text { Non } \\
- \\
\text { state }\end{array}$ & $\begin{array}{l}\text { Sta } \\
\text { te }\end{array}$ & $\begin{array}{l}\text { Differe } \\
\text { nce }\end{array}$ & $\begin{array}{l}\text { No } \\
\text { n- } \\
\text { FD } \\
\text { I }\end{array}$ & $\begin{array}{l}\text { FD } \\
\text { I }\end{array}$ & $\begin{array}{l}\text { Differe } \\
\text { nce }\end{array}$ \\
\hline $\begin{array}{l}\text { Not follow the policy's } \\
\text { regulations }\end{array}$ & $2 \%$ & $0 \%$ & $1.6 \%$ & $-0.015^{*}$ & $2 \%$ & $1 \%$ & 0.012 & $1 \%$ & $2 \%$ & -0.005 \\
\hline $\begin{array}{l}\text { Adjust their activities } \\
\text { alongside to the policy }\end{array}$ & $68 \%$ & $56 \%$ & $49 \%$ & 0.066 & $46 \%$ & $\begin{array}{l}59 \\
\%\end{array}$ & -0.129 & $\begin{array}{l}55 \\
\%\end{array}$ & $\begin{array}{l}42 \\
\%\end{array}$ & $0.128^{*}$ \\
\hline
\end{tabular}




\begin{tabular}{|l|l|l|l|l|l|l|l|l|l|l|}
\hline $\begin{array}{l}\text { Actively send } \\
\text { feedbacks to the State } \\
\text { bodies }\end{array}$ & $37 \%$ & $19 \%$ & $28 \%$ & -0.089 & $42 \%$ & $\begin{array}{l}19 \\
\%\end{array}$ & $0.223 *$ & $\begin{array}{l}26 \\
\%\end{array}$ & $\begin{array}{l}33 \\
\%\end{array}$ & -0.074 \\
\hline $\begin{array}{l}\text { Actively send } \\
\text { feedbacks to business } \\
\text { associations }\end{array}$ & $48 \%$ & $36 \%$ & $37 \%$ & -0.007 & $29 \%$ & $\begin{array}{l}38 \\
\%\end{array}$ & -0.085 & $\begin{array}{l}35 \\
\%\end{array}$ & $\begin{array}{l}46 \\
\%\end{array}$ & -0.104 \\
\hline
\end{tabular}

Source: Survey Results of the Research Team (2013)

Note: $*, * *, * * *$ denote for significant level at $1 \%, 5 \%$ and $10 \%$

Table 13 shows that enterprises' attitude is quite positive even when the policy comes into effective and it affects negatively their activities. While $98 \%$ of surveyed enterprises will adjust their activities and send feedbacks for adjustment as they see the negative impact of the policy, only $2 \%$ of them are not going to follow the policy's regulation. It implies a positive signal for the Government in policy implementation. However, the choice of adjusting their activities alongside with the policy gets the highest proportion of $68 \%$ of responses. It implies that enterprises seem to be inactive when the policy could affect their activities.

Beside the first response of adjustment their operation, $48 \%$ of surveyed enterprises at both areas and in all types of ownership acknowledge that they will send their feedbacks to the State agencies rather than via associations. Then, $37 \%$ of responses could actively send feedbacks to the State bodies. The non-state enterprises tend to agree with that choice more than the state enterprises ( $42 \%$ and $19 \%$ of each type of companies respectively).

We find the evidence that enterprises in the North have a comparative tendency of not to follow regulations. In addition, there is different opinion between FDI and non-FDI companies in adjusting their operation. The possible reason is that North location or non-FDI presence encourages them to depend on the weak enforcement of regulations seeking opportunity to "lobby" the revision of the policy.

\subsubsection{When does the trade policy consultation process occur?}

Table 4.12 shows evaluating the importance of the enterprise's participation in formulation and implementation of trade policy at each stage. The enterprises seem to prefer to participate into the stage of post-approval of policy. 
Table 4.12. The importance of the enterprise's participation in formulation and implementation of trade policy at each stage

\begin{tabular}{|c|c|c|c|c|c|c|c|c|c|c|}
\hline \multirow[b]{2}{*}{ Stage } & \multirow[b]{2}{*}{$\begin{array}{l}\text { Avera } \\
\text { ge }\end{array}$} & \multicolumn{3}{|c|}{ By Headquarter } & \multicolumn{3}{|c|}{$\begin{array}{l}\text { Between State and } \\
\text { Non-state } \\
\text { enterprises }\end{array}$} & \multicolumn{3}{|c|}{$\begin{array}{l}\text { Between FDI and } \\
\text { Non-FDI } \\
\text { enterprises }\end{array}$} \\
\hline & & $\begin{array}{l}\text { The } \\
\text { Sout } \\
\text { h }\end{array}$ & $\begin{array}{l}\text { The } \\
\text { Nort } \\
\text { h }\end{array}$ & $\begin{array}{l}\text { Differen } \\
\text { ce }\end{array}$ & $\begin{array}{l}\text { No } \\
\text { n- } \\
\text { stat } \\
\text { e }\end{array}$ & $\begin{array}{l}\text { Stat } \\
\text { e }\end{array}$ & $\begin{array}{l}\text { Differen } \\
\text { ce }\end{array}$ & $\begin{array}{l}\text { No } \\
\text { n- } \\
\text { FDI }\end{array}$ & $\begin{array}{l}\text { FD } \\
\text { I }\end{array}$ & $\begin{array}{l}\text { Differen } \\
\text { ce }\end{array}$ \\
\hline $\begin{array}{l}\text { Preparation } \\
\text { for } \\
\text { negotiating } \\
\text { international } \\
\text { agreements }\end{array}$ & 2.5 & 3.2 & 2.3 & $0.917^{*}$ & 2.4 & 2.4 & 0.917 & 2.4 & 2.8 & $-0.423^{*}$ \\
\hline $\begin{array}{l}\text { In the } \\
\text { process of } \\
\text { negotiation }\end{array}$ & 2.5 & 2.8 & 2.4 & 0.386 & 2.3 & 2.4 & 0.386 & 2.4 & 2.9 & $-0.5^{*}$ \\
\hline $\begin{array}{l}\text { At the end } \\
\text { of } \\
\text { negotiation } \\
\text { and } \\
\text { Preparing } \\
\text { approval of } \\
\text { agreements }\end{array}$ & 2.4 & 2.5 & 2.3 & 0.237 & 2.3 & 2.3 & 0.237 & 2.3 & 2.7 & $-0.489^{*}$ \\
\hline Policy draft & 2.9 & 3.2 & 2.7 & $0.506^{*}$ & 2.8 & 2.7 & 0.506 & 2.8 & 3.0 & -0.279 \\
\hline $\begin{array}{l}\text { Finishing } \\
\text { policy draft } \\
\text { and start to } \\
\text { launch the } \\
\text { policy }\end{array}$ & 2.9 & 3.1 & 2.8 & $0.363^{*}$ & 2.9 & 2.8 & 0.363 & 2.8 & 3.0 & -0.252 \\
\hline $\begin{array}{l}\text { Policy } \\
\text { Implementat } \\
\text { ion }\end{array}$ & 3.2 & 3.6 & 3.1 & $0.514 *$ & 3.3 & 3.1 & 0.514 & 3.1 & 3.4 & -0.247 \\
\hline
\end{tabular}

Source: Survey Results of the Research Team (2013)

Note: $*, * *, * * *$ denote for significant level at $1 \%, 5 \%$ and $10 \%$

Average level $1 \rightarrow 2 \rightarrow 3 \rightarrow 4$ denote for unnecessary $\rightarrow$ Necessity but Unimportant $\rightarrow$ Important $\rightarrow$ Very Important level 
According to surveyed enterprises, they appreciate the stage of policy implementation for participation as $100 \%$ of responses see this period is "important" and "very important" time (and reach the highest point at 3.2 out of 4 at average level).

\section{Box 2: Low perception of enterprises on the Trans-Pacific Partnership Agreement at early stage}

The Trans-Pacific Partnership Agreement (TPP) is considered as the "FTA of $21^{\text {st }}$ century". For Vietnam, the TPP is an important FTA as it covers a wide range of issues from traditional trade to non-traditional trade-related issues (e.g. labour or environment).

Upon receiving the invitation to the TPP in 2009, Vietnam has participated in the TPP as associate member (observer) for 3 negotiation rounds. During that period, after that there was a study carried by the Institute of Trade (which belongs to the MOIT) on the feasibility of Vietnam's joining TPP (said by Ngo Chung Khanh, 2012). Based on the study's results, there was supposed to have the Politburo's decision to join the TPP. So, in November 2010, at the APEC's summit, Vietnam has officially announced the decision to join the TPP. So, since 2010, Vietnam has officially be a member of this $21^{\text {st }}$ century agreement. But the early stage of deciding to join the TPP was discussed within the government sectors without evidence of consultation with private sector.

A survey in 2011 revealed the low awareness of enterprises on the TPP, even though Vietnam had negotiated it for 1 year. While $32.8 \%$ of respondents never heard about the TPP, $34.3 \%$ has heard the word "TPP" but did not have any understanding, the rest of $32.8 \%$ just had a basic knowledge (Dao Ngoc Tien, 2012).

However, a repeated survey with the same sample in 2013 revealed an improvement. At this time, more than $60 \%$ of respondents has expressed that they received information on the TPP over the last year, resulted in their basic knowledge. However, the main channel is mass media (newspaper or television), rather than the activities of either government or association.

There shows no signs of significant difference by types of ownership but there exists contrast opinion between the Northern and the Southern ones in which the business in the South agree more with the choice than the ones in the North.

Besides, the second average level of 2.9 is stage of drafting the policy and policy launching preparation. While the Southern enterprises are more acknowledged of the selection than the Northern ones, the business in all types of ownership have similar opinion on the stage that they should participate into the trade policy process. 
On the other hand, enterprises consider the stage of preparation for agreement negotiation and in the process of negotiation as the third "important" level for consultation ( 2.5 out of 4 points at average level). As for the choice of negotiation preparation stage, Southern enterprises are more agreeable with the idea than the Northern ones. The non-FDI business agrees less with the chose than the FDI enterprises. And there is no difference between the state and non-state business.

The enterprises' choice on period for participation into trade policy making- process does not go along with the target of their advocacy of policy negotiators (Table 12). While the enterprises target policy negotiators (officials in ministries) who join the preparation for policy negotiation and in the process of negotiation in order to influence the policy, they consider the stage of postapproval of policy as most important stage for consultation. It implies that the Vietnamese enterprises have not captured their role in active influence of trade policy- making process.

\subsubsection{What are the challenges in trade policy consultation process?}

Table 4.13 shows us so many challenging barriers that prevent the enterprises from further participating into trade policy process.

Table 4.13: Challenges preventing enterprises from further participating into Trade policy process

\begin{tabular}{|c|c|c|c|c|c|c|c|c|c|c|}
\hline \multirow{2}{*}{$\begin{array}{l}\text { The enterprises' } \\
\text { attitude }\end{array}$} & \multirow[b]{2}{*}{$\begin{array}{l}\text { Perce } \\
\text { ntage }\end{array}$} & \multicolumn{3}{|c|}{ By Headquarter } & \multicolumn{3}{|c|}{$\begin{array}{l}\text { Between State } \\
\text { and Non-state } \\
\text { enterprises }\end{array}$} & \multicolumn{3}{|c|}{$\begin{array}{l}\text { Between FDI } \\
\text { and Non-FDI } \\
\text { enterprises }\end{array}$} \\
\hline & & $\begin{array}{l}\text { The } \\
\text { Sout } \\
\text { h }\end{array}$ & $\begin{array}{l}\text { The } \\
\text { Nort } \\
\text { h }\end{array}$ & $\begin{array}{l}\text { Diffe } \\
\text { renc } \\
\text { e }\end{array}$ & $\begin{array}{l}\text { Non } \\
- \\
\text { state }\end{array}$ & $\begin{array}{l}\text { Stat } \\
\text { e }\end{array}$ & $\begin{array}{l}\text { Diff } \\
\text { eren } \\
\text { ce }\end{array}$ & $\begin{array}{l}\text { No } \\
\text { n- } \\
\text { FDI }\end{array}$ & FDI & $\begin{array}{l}\text { Diffe } \\
\text { renc } \\
\text { e }\end{array}$ \\
\hline $\begin{array}{l}\text { Lack of essential } \\
\text { knowledge }\end{array}$ & $36 \%$ & $11 \%$ & $29 \%$ & $\begin{array}{l}- \\
0.17 \\
8 *\end{array}$ & $21 \%$ & $\begin{array}{l}32 \\
\%\end{array}$ & $\begin{array}{l}- \\
0.10 \\
7\end{array}$ & $\begin{array}{l}28 \\
\%\end{array}$ & $\begin{array}{l}23 \\
\%\end{array}$ & $\begin{array}{l}0.05 \\
5\end{array}$ \\
\hline $\begin{array}{l}\text { Policy belong to the } \\
\text { Government's concern }\end{array}$ & $16 \%$ & $11 \%$ & $12 \%$ & $\begin{array}{l}- \\
0.00 \\
4\end{array}$ & $8 \%$ & $\begin{array}{l}16 \\
\%\end{array}$ & $\begin{array}{l}- \\
0.07 \\
4\end{array}$ & $\begin{array}{l}14 \\
\%\end{array}$ & $7 \%$ & $\begin{array}{l}0.06 \\
5\end{array}$ \\
\hline Time constraint & $11 \%$ & $14 \%$ & $6 \%$ & $\begin{array}{l}0.07 \\
5\end{array}$ & $4 \%$ & $\begin{array}{l}10 \\
\%\end{array}$ & $\begin{array}{l}- \\
0.05 \\
4\end{array}$ & $8 \%$ & $7 \%$ & $\begin{array}{l}0.01 \\
0\end{array}$ \\
\hline $\begin{array}{l}\text { Not have trade related } \\
\text { information }\end{array}$ & $45 \%$ & $42 \%$ & $31 \%$ & $\begin{array}{l}0.11 \\
1\end{array}$ & $38 \%$ & $\begin{array}{l}35 \\
\%\end{array}$ & $\begin{array}{l}0.02 \\
4\end{array}$ & $\begin{array}{l}36 \\
\%\end{array}$ & $\begin{array}{l}26 \\
\%\end{array}$ & $\begin{array}{l}0.09 \\
4\end{array}$ \\
\hline Not have channels for & $46 \%$ & $42 \%$ & $32 \%$ & 0.10 & $25 \%$ & 39 & - & 35 & 33 & 0.01 \\
\hline
\end{tabular}




\begin{tabular}{|l|l|l|l|l|l|l|l|l|l|l|}
\hline comments & & & 0 & & $\%$ & $\begin{array}{l}0.13 \\
5^{*}\end{array}$ & $\%$ & $\%$ & 2 \\
\hline $\begin{array}{l}\text { Not receive the } \\
\text { feedbacks from the } \\
\begin{array}{l}\text { Government bodies on } \\
\text { previous comments }\end{array}\end{array}$ & $36 \%$ & $33 \%$ & $24 \%$ & $\begin{array}{l}0.09 \\
1\end{array}$ & $31 \%$ & $\begin{array}{l}26 \\
\%\end{array}$ & $\begin{array}{l}0.04 \\
9\end{array}$ & $\begin{array}{l}28 \\
\%\end{array}$ & $\begin{array}{l}22 \\
\%\end{array}$ & $\begin{array}{l}0.04 \\
9\end{array}$ \\
\hline
\end{tabular}

Source: Survey Results of the Research Team (2013)

Note: $*, * *, * * *$ denote for significant level at 1\%, 5\% and $10 \%$

According to the result shown in Table 15, the most challenge for enterprises to participate in trade-policy making is not having channels for comments (46\%). It implies that enterprises do not know where/who/how to make suggestions and deliver their messages to influence the policy. Further interview shows that they even never have a chance to provide the information for trade policy making. Other responded state-owned enterprises said that many policies were launched without asking for the enterprises' comments in advance, and that they received late adjustment and feedbacks after they sent responses for a long time, resulting in harmful impacts. Besides, state-owned companies seem to suffer more from this lack of information non-state owned enterprises. It also shows that lacking of channel for suggestion/comment is a common weakness for all business community, and there is no priority for state-owned enterprisesin trade policy consultation.

Moreover, enterprises consider lacking of trade related information as the second difficult barrier preventing them from engaging in trade policy process (45\% of the responses). Consequently, the Government's current channels for supplying the information are not effective, and enterprises needs more trade related information.

In addition, lacking of essential knowledge as well as feedbacks from the Government bodies on previous comments are the third challenges that enterprises face during their participation into the trade policy making process (both get 36\%). Southern enterprises admit less that they are lack of necessary knowledge than the Northern ones, implying that they feel more confident on their knowledge on trade policy and trade related issues. However, they all need further training by themselves and by the Government. Besides, the enterprises are not eager to make more suggestions because they suspect whether their opinions could be recognized by the Government's bodies. So, it's advisable to make an official and compulsory channel for information exchange between the State and enterprises in order to assure that the business community has an official approach when they involve in the trade policy process.

The small proportion of $11 \%$ of responses identifying barrier on time constraint shows that the enterprises see their important role in the trade policy making- process, and that they are willing 
to participate into the consultation mechanism. The test shows no conflict idea among enterprises in all types of ownership and at both headquarters.

In general, enterprises' participation in trade policy making- process in Vietnam is somehow passive due to many reasons. Firstly, they do not have official channel or mechanism to participate into the process, their engagement depends on the Government's intention. If the Government would like to ask for consultation from the enterprises, they could send official letter to request information or organize some conferences to get the idea. Therefore, the Government needs to legally regulate official mechanism for the enterprises to participate into trade policy - making process from preparation for negotiation to policy implementation stage. Secondly, enterprises are still not active in influencing the policy. They need to clearly indentify the target of their advocacy and choice the right the moment to influence. Thirdly, the enterprises are still lack of essential knowledge in trade related issues, so they must join training courses on trade matters and other analysis skills. Last but not least, the communicating of policy exchange and discussion between the State and the business community is not effective. As a result, the Government should find out an effective two-way communication between them and enterprises so that the Government could receive regular suggestions and comments from the enterprises and the non-state actors in turn get feedbacks and could self-interact directly to the Government. It's advisable to improve the business associations' capacity as a common and effective channel for information exchange between the Government and the enterprises community.

\section{Box 3: Challenges to trade policy formulation in African countries}

Firstly, limited technical knowledge, financial, and human capacity are indicated as obvious challenges to non-state actors in the countries under research. These difficulties should be the common barriers to policy making process in developing countries which may prevent prompt feedback from the government bodies to the non-state actors' contribution during the consultations (CUTS 2009).

Secondly, the most challenging obstacle for the non-state government sectors in the consultation stage is how to balance different interests among members under the "multi-sector umbrella". Without clear, consistent voice, their ability of contributing to the policy making process is limited (CUTS 2009).

Thirdly, one has to question the efficiency of long term development framework (CUTS 2009). In the research of CUTS, all five African countries issued the so - called Vision documents to 2020, 2025 and 2030 respectively at the time of the research to sketch long term development policies, supported by National Trade Policy, other supporting documents and sectoral strategies, and governmental strategic programs. It is noted by CUTS that countries tend to move away from a consistent long term strategy to achieve more medium term development results, and that 
they do not regularly update the vision alongside with reality needs, and the implementation of such national policies often lack efficiency.

Sources: Kaukab.R.S et al (2009, 2010) and two interviews with Kaukab.R.S et al (2010) at CUTS Geneva Resource Centre) in December 2012 and January 2013 


\section{CHAPTER 5: CONCLUSIONS AND RECOMMENDATIONS}

Vietnam has laid the initial legal foundation for consultation in trade policy development. As a result, the consultation situation in the country has appeared in all 3 possible forms: interministries, business-focus and multi-stakeholder consultations.

The current consultation of trade policy in Vietnam can be divided into 3 layers, based on relationships between the bodies. The core layer with frequent and effective consultation includes those currently working in state sector, including government research institutes. At the centre of this core layer is the operation of MoIT as the main ministry relating to trade policy and NCIEC as the inter-ministries coordinating agency. However, this should not be considered as the consultation as all the actors are government with different policy making authority. Expanding from this core, the second layer will includes those are former governmental officials (head of business associations) and VCCI, which has a "special" relation with government. It is a part of business-focus consultation as it only allows indirect interaction rather than direct between enterprises and government.

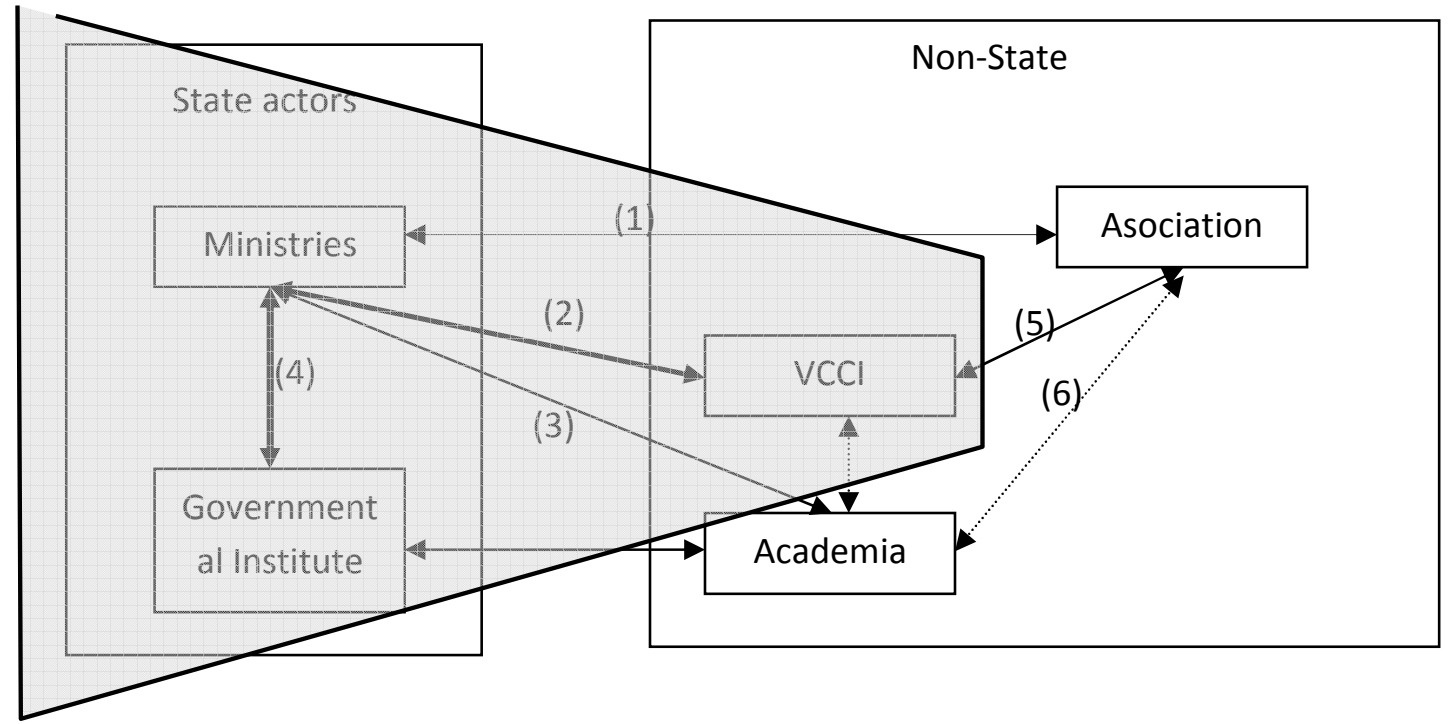

Figure 5.1. The spheres of State Actors and Non-State Actors in the trade formulation in Vietnam

The outer layer includes enterprises and academia that can only affect trade policy indirectly. However, in this layer, also depending on personal relationship, there are some enterprises more involved in the trade policy consultation. Enterprises in the North with geographical proximity and state-owned enterprises with channels of capital control and representativeness have participated more in the consultation process. The others, such as companies in the South, FDI and private enterprises, even though are more economic dynamic but are more passive in 
involving in trade policy making. They put high expectation on efficiency of trade policy consultation toward their benefits.

Resulted from the motivation for participation, the consultation does not assure effective twoway communications as it need to be. Currently, with the weak capacity in dealing with conflicted interest groups, it seems that the government just tries to disclose information to satisfy transparency requirement. On receiving information, preferred channel to reach out to non-state actors of the government is through business associations, and VCCI, which already processes the conflicted problems to some extent. From enterprises, with the expectation that the policy will be beneficial for their own enterprises, the above accessible indirect mechanism seem not to be satisfactory for them, so they gradually move to the outer layer of the consultation process.

\section{Box 4: How to address challenges in trade policy consultation in African countries \\ How to address challenges posed by limited technical, financial and human capacity of non-state actors in their engagement in the policy making process}

CUTS researches suggest that resources to build stakeholders' financial and human capacity should be assigned to the ministries responsible for trade. CUTS also mentioned in their latest research of the issue in 2010, "Inclusiveness of Trade Policy-Making: Challenges and Possible Responses for Better Stakeholder Participation", that the African countries in research receive funding support from abroad, especially from the EU. Nevertheless, the funding seems to encourage multi-stakeholder consultative mechanisms on specific trade issues while policies covering broader issues tend to be processed by only governmental or public-private sectors. Hence, governments should control the fund in a way that ensures non-differential chances for different groups of non-state actors to get themselves involve in the trade policy making process. On the technical part, information dissemination and awareness-raising activities should be organized by the government and all stakeholders.

\section{How to ensure the involvement of non-state actors}

Consultative mechanism should be enhanced to cover all priority trade issues and function properly to ensure two - way information and feedback flow between government and non - state actors. Relevant government bodies and agencies should coordinate to ensure coherent information, procedures and resulting of the process. The same applies for different stakeholders, as they need to find common ground to base their interests and come up with a common voice. Only when a healthy, constructive dialogue connecting the policy makers with different stakeholders is built could the trade policy making process be inclusive and participatory. Nonetheless, participation of non - state actors should not be limited to purely opinion sharing. Governments need to perform their functions in evaluating, taking into account, and 
incorporating various stakeholders' opinions and interests in their policy making process, including the negotiation, drafting and implementation of such policies.

A legal mandate should be adapted in further details by how much by the government to recognize the response, comments and proposals of non-state actors in the trade policy making process as well as stipulate state agencies to involve non-state actors' opinions and interests in their policy drafting, negotiating and implementing.

\section{How to balance different interests among members in the society}

It is of great importance to improve and diversify the involvement of various stakeholders in the policy making process. More stakeholders (e.g. representatives of consumers, small traders, farmers, civil society associations, etc.) be identified and included in the consultative mechanisms.

Ensuring and improving regular information flow actively to various stakeholders is also important to create understandings of different social groups. Stakeholders should be equipped with more awareness and regular information flow from the Ministry of Trade or other government bodies responsible in the policy making process. When stakeholders are well aware and fully capture the trade issues as well as their potential impacts on their business/activities, they would then be ready to contribute responsively, actively and effectively in the policy making process.

In recent few years, after the Decision 60/QD-TTg, the business consultation has been improved with the legally mandatory point of consultation of VCCI's advisory committee on international trade policy. However, there is much improvement need to be done, including detailed and specific regulation on consultation:

- There should be more actors to be involved as each has their own advantages that supplementary contribute to the quality of consultation which is currently a coordinating work between government (including governmental institute) and association (especially VCCI). Firstly, the academia can provide research-based report and impact forecast that not only support the policy decisions of government but also help "private loser" become more tolerant with the policy. Secondly, the enterprises should directly interact with the government as it will motivated them to participate further in the process as well as providing practical, update and details information on their own operation. Lastly, other non-state actors can somehow balance the benefits and loss of different players. But given the currently limited representative and neutrality of business associations, besides VCCI, other foreign chambers of commerce as well as civil social societies should be involved.

- The governments should not only post information on their website but have regular conference/seminar with private sectors. In the conference, there will be a discussion between state and private sectors. In the other case, rather than "posting", government should create 
forum for consultation in their website, which allow enterprises to received feedbacks to their opinions within specified periods.

- Awareness and capacity of all sectors need to be enhanced. As the consultation process should be a two-way communications, where each sides can send and receive information. So it will depend on the aware benefits of receiving, ability to analyze information of each side. In this aspect, efforts need to be spent on training all actors (enterprises, association and even government) on trade policy consultation. 


\section{References}

1. “Các tập đoàn kinh tế" (Corporates), Website of the Government of Vietnam http://m.chinhphu.vn/gov/article/view/41/146/ (accessed June 10, 2013)

2. "Cần một cuộc chỉnh đốn thật sự ở VCCI" (A real reform is needed in VCCI), Nhan Dan (People) Newspaper, http://www.nhandan.com.vn/chinhtri/dang-va-cuocsong/item/19908902-c\%E1\%BA\%A7n-m\%E1\%BB\%99t-cu\%E1\%BB\%99cch\%E1\%BB\%89nh-\%C4\%91\%E1\%BB\%91n-th\%E1\%BA\%ADt-s\%E1\%BB\%B1\%E1\%BB\%9F-vcci.html (accessed July 20, 2013)

3. "Danh sách các Hiệp hội Việt Nam" (List of associations in Vietnam), Website of the MoIT, http://hiephoi.moit.gov.vn/default.aspx?cat_Id=1 (accessed August 13, 2013)

4. "Indian trade policy since the Uruguay Round", Dhar.B and Kallummal.M, Reference made from the topic "Trade policy off the hook: The making of Indian trade policy since the Uruguay Round" in Wolfe. R and Helmer.J et al (2007)

5. "Tư liệu bầu cử Quốc Hội” (Documents for National Assembly Election), Website of the National Assembly of Vietnam, http://na.gov.vn/htx/Vietnamese/C1454/C1455/\#wEw0i66CExCm (accessed June 8, 2013)

6. "Ủy ban tư vấn”, Counseling Council, VCCI's WTO Centre website http://trungtamwto.vn/uy-ban-tu-van (accessed June 9, 2013)

7. Ann Capling and Patrick Low (2010), “Governments, Non-state actors and Trade Policy making: Negotiating preferentially or Multilaterally”, Cambridge University Press

8. Brian Hockling (2004), in his article of "Changing the terms of trade policy making: from the 'club' to the 'multi-stakeholder' model”, World Trade Review 2004, 3: 1, 3-26

9. COMINGO, VUFO and PACCOM, VUFO-NGO Resource Centre Vietnam http://www.ngocentre.org.vn/content/comingo-vufo-and-paccom (accessed July 7, 2013)

10. Committee on International Trade Policies, VCCI's WTO Centre website http://wtocenter.vn/citp (accessed June 19, 2013)

11. Curtis, "Trade and Civil Society", p. 306

12. CUTS international (2009), "Towards More Inclusive Trade Policy Making: Process and Role of Stakeholders in Select African Countries”, ISBN: 978-81-8257-123-5

13. Dao Ngoc Tien, 2012, opportunity and challenges to Vietnam's participation in the TPP, presentation at the National Assemby's seminar, Tamdao, Vinh Phuc province $27+28 / 8 / 2012$.

14. Deepta Chopra (2010), "Policy Making in India: A Dynamic Process of Statecraft", Pacific Affairs: Volume 84, No. 1 - March $2011 \backslash$

15. Dordi. C (2012), "SMEs assisted with lobby instruments", available online at http://www.vir.com.vn/news/features/smes-assisted-with-lobby-instruments.html

16. Dymond and Dawson (year), 'The Consultative Process', pp. 15-16.

17. Heng Wang (year), "Enhancing Business Participation in Trade Policy-Making: Lessons from China”, The International Development Research Cente, 
18. Hyun-Seok, Yu (2003), "Transnational actors and foreign policy making in South Korea: The case studies”, Korea Observer; Summer 2003; 34, 2; ProQuest Central pg. 245

19. Introduction to the Vietnam Chamber of Commerce and Industry, VCCI Website http://vccinews.com/aboutvcci.asp (accessed July 4, 2013)

20. Kenichi Ohno (2010), "Đổi mói quy trình làm chính sách của Việt Nam”( The Innovation in Vietnamese policy making process), available online at http://www.pvnamchienluoc.com/pictures/file/doimoicachlamchinhsach-01_131791406650.pdf

21. Kevin McKague (2011), "Dynamic capabilities of institutional entrepreneurship”,

22. KIPPRA (2007), "Trade Policy-Making Process in Kenya: The Institutional Arrangements and Interaction of Actors",

23. Letter of 23 July 2001, US - Vietnam Trade Council http://www.usvtc.org/trade/bta/letters/congress_23Jul2001.htm (accessed July 25, 2013)

24. Ministry of Information and Communications, "Việt Nam vào top 20 quốc gia có nhiều người dùng Internet nhất", http://mic.gov.vn/tintucsukien/tintuctrongnganh/Trang/Vi\%E1\%BB\%87tNamv\%C3\%A0oto p20qu\%E1\%BB\%91cgiac\%C3\%B3nhi\%E1\%BB\%81ung\%C6\%B0\%E1\%BB\%9Did\%C3\% B9ngInternetnh\%E1\%BA\%A5t.aspx, accessed March 20, 2013

25. Ngo Chung Khanh, 2012, Vietnam's participation in the TPP, presentation at the National Assemby's seminar, Tamdao, Vinh Phuc province 27+28/8/2012.

26. R. Keohane and J. Nye (2000), "The Club Model of Multilateral Co-Operation and the WTO: Problems of Democratic Legitimacy", paper presented at a conference on 'Efficiency, Equity and Legitimacy: The Multilateral Trading System at the Millennium', Kennedy School of Government, Harvard University,1-2 June 2000.

27. Rashid S Kaukab (2009), "Improving ownership through inclusive trade policy making processes: Lessons from Africa”, CUTS International, ISBN 978-81-8257-122-8

28. Rashid S Kaukab (2009), “Towards more inclusive trade policy making: Process and Role of stakeholders in select African countries”, CUTS International, ISBN ISBN 978-81-8257123-5

29. Rashid S Kaukab (2010), "Inclusiveness of Trade Policy-Making: Challenges and Possible Responses for Better Stakeholder Participation”, Commonwealth issue 70, online available at http://www.cuts-grc.org/pdf/FEATS-Research_Report-Trade_Policy.pdf

30. Robert A.Rogowsky (2012), Training course on "Trade Negotiation", Foreign Trade University, Ha Noi, Vietnam 12/2012

31. Starting a business in Vietnam, Doing Business http://www.doingbusiness.org/data/exploreeconomies/vietnam/starting-a-business/ (accessed July 28, 2013)

32. Starting and operating an INGO, VUFO-NGO Resource Centre Vietnam http://www.ngocentre.org.vn/content/starting-and-operating-ingo (accessed July 7, 2013)

33. Towards Concrete Actions, VCCI Website 
http://vccinews.com/news_detail.asp?news_id=28579 (accessed August 17, 2013)

34. Trần Lăng (2011), "Cộng đồng doanh nghiệp Việt Nam \& hành trình tham gia đàm phánthực thi cam kết quốc tế: Tín hiệu vui 2011"( Vietnamese Enterprise Association and the process to participate in the international negotiation and commitment) (The journal of legislation), available online at http://phaply.net.vn/kinh-doanh-phap-luat/doanh-nghiepkinh-doanh-phap-luat/cong-dong-doanh-nghiep-viet-nam-hanh-trinh-tham-gia-dam-phanthuc-thi-cam-ket-quoc-te-tin-hieu-vui-2011.html

35. Trevor Simumba (2009), "Private Sector Participation in Aid for Trade: Breaking Barriers to Private Sector Growth”, European Centre for Development Policy Management,

36. Tuổi trẻ online (Youth newspaper), (2013), Is TPP beneficial for processing enterprises? (TPP có giành cho doanh nghiệp gia công?), http://tuoitre.vn/kinh-te/564462/tpp-co-danhcho-doanh-nghiep-gia-cong.html

37. Văn phòng Ủy ban Quốc gia về hợp tác kinh tế Quốc tế, MoIT website http://moit.vecita.gov.vn/ (accessed June 27, 2013)

38. VEF (2013), The government "reject" VAMA's position on lowering tariff (Chính phủ "bác" đề nghị giảm thuế phí của VAMA), http://news.benhvienoto.vn/detail/434/Chinh-phu-bacde-nghi-giam-thue-phi-cua-VAMA.html

39. VCCI (2010), "Báo cáo nghiên cúu doanh nghiệp và chính sách thuơng mại quốc tế" (Research report on Enterprises and International Trade Policies), available online at http://trungtamwto.vn/viewer/vn/an-pham-khac/bao-cao-nghien-cuu-dn-va-cstmqt/index.html

40. VCCI continues to represent Vietnamese business community, VOV http://english.vov.vn/Economy/Investment/VCCI-continues-to-represent-Vietnamesebusiness-community/259740.vov (accessed July 24, 2013)

41. Vietnam Chamber of Commerce and Industry, Proportion of enterprises by size of capital in the period 2005 - 2010, 'Vietnam Business Annual Report 2011', Information and Communication Publishing House, Hanoi, March 2012

42. Vietnam's trade union holds 11th congress, Communist Party of Vietnam Online Newspaper http://dangcongsan.vn/cpv/Modules/News_English/News_Detail_E.aspx?CN_ID=599319\& CO_ID $=30180$ (accessed July 12, 2013)

43. Vietnamleader (2010), "Trông người mà ngầm đến ta" (The experience from other countries' policy making process), available online at http://www.vietnamleader.com/home/141-ban-va-lun-chung/1261-trong-ngi-ma-ngm-nta.html

44. VUFO-NGO Resource Centre, Report on the 2003 members' survey, http://www.ngocentre.org.vn/content/annual-reports (accessed July 7, 2013)

45. Walter Odhiambo and Gloria Otieno (2005), "Trade Policy Reforms and Poverty in Kenya: Processes and Outcomes" (KIPPRA), 
46. Who Drives Economic Reform in Vietnam's Provinces?, Institute of Development Studies http://www.ids.ac.uk/publication/who-drives-economic-reform-in-vietnam-s-provinces (accessed August 3, 2013) 


\section{Appendix I: Questionnaire}

\section{A. For Enterprises}

The Foreign Trade University (Hanoi, Vietnam) is conducting a research on the participation of enterprises in the international trade policy formulation and implementation process. We highly appreciate your time answering our questionnaire.

Please kindly note that the multiple choices in the questionnaire is acceptable.

All the survey results will be released after fully statistically processed.

Please do not hesitate to contact Dr. Dao Ngoc Tien at dntien@ftu.edu.vn or via mobile phone number 0913566677 for detailed information.

\section{Name of the enterprise:}

\section{Type of the enterprise's business ownership:}

F. Local enterprises with more than $50 \%$ capital funded by the Government.

G. Local enterprise with less than $50 \%$ capital funded by the Government.

H. Private enterprise (without funding from the Government)

I. Joint - venture.

J. Foreign owned enterprise.

\section{Enterprise's activities:}

A. Commodity production

B. Commodity exporting

C. Service trading

D. Commodity importing

E. Others (please specify):

4. Enterprise's trading areas (main products, industry):............

5. Evaluating the effects from Government bodies' policies to the enterprise:

\begin{tabular}{|l|l|l|l|l|}
\hline \multicolumn{1}{|c|}{ Government body } & $\begin{array}{c}\text { Not being } \\
\text { influenced }\end{array}$ & $\begin{array}{c}\text { Modestly } \\
\text { being } \\
\text { influenced }\end{array}$ & $\begin{array}{c}\text { Significantly } \\
\text { being } \\
\text { influenced }\end{array}$ & $\begin{array}{c}\text { Fully } \\
\text { being } \\
\text { influenced }\end{array}$ \\
\hline Ministry of Defense & & & & \\
\hline Ministry of Public Security & & & & \\
\hline Ministry of Foreign Affairs & & & & \\
\hline Ministry of Justice & & & & \\
\hline Ministry of Finance & & & & \\
\hline
\end{tabular}




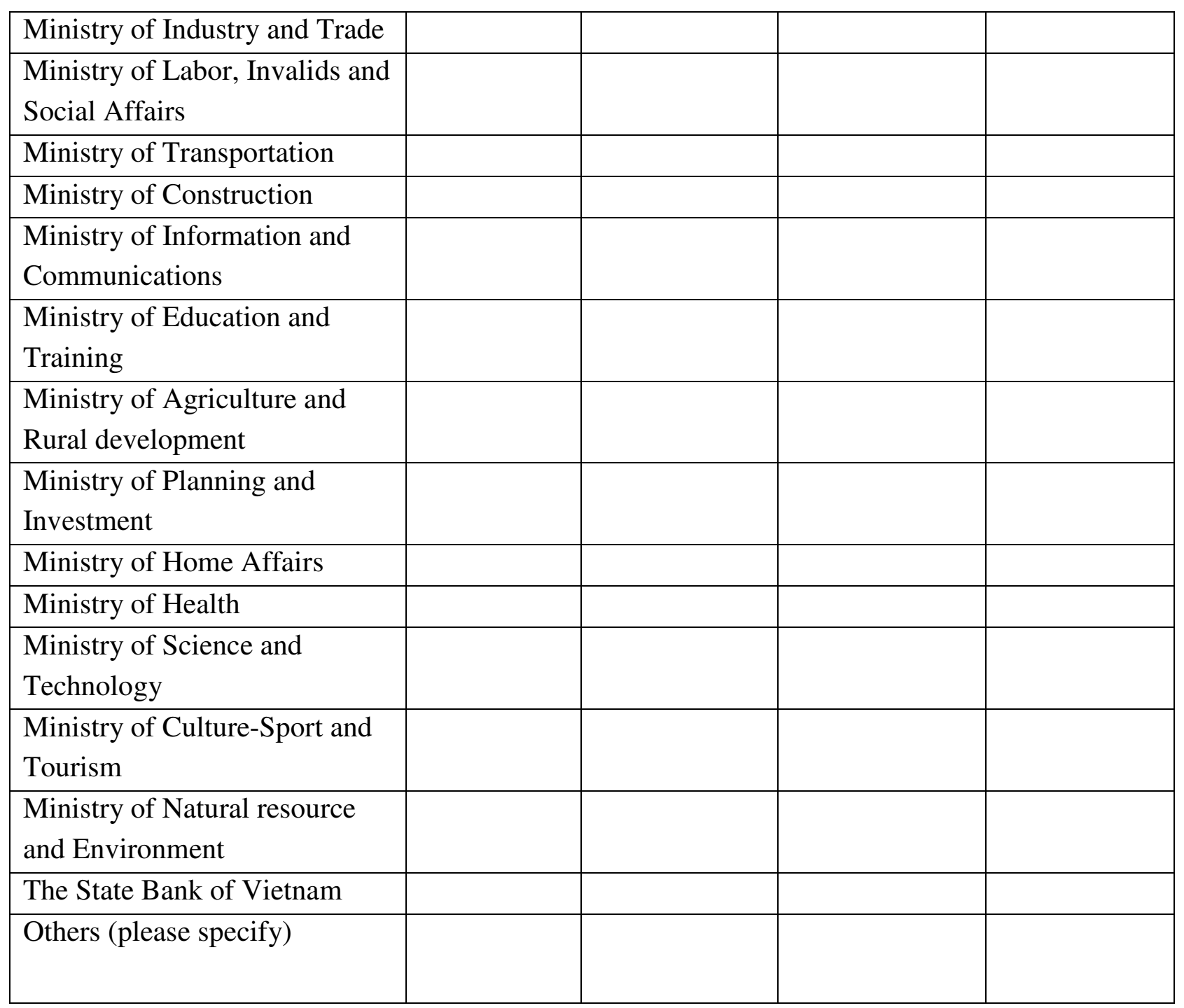

\section{Why should the enterprise participate in the trade policy making process?}

A. To provide the practical information to related Government bodies.

B. To get the benefits from appropriate policies.

C. For the common benefit of the industry and society.

D. Others (please specify):

7. From which source(s) does the enterprise get related targeting/drafting information about the trade policies?

A. Meetings between the enterprises and Government representatives organized by the Government body (bodies).

B. Academic seminars and conferences. 
C. The Association of enterprises.

D. The mass media (including government bodies' websites).

8. Understanding of enterprises about trade policies (please tick $X$ into the appropriate rows)

\begin{tabular}{|l|l|l|}
\hline \multicolumn{1}{|c|}{ Content } & True & False \\
\hline $\begin{array}{l}\text { The enterprise only can figure out (without analysis) the possible } \\
\text { effects from the trade policies }\end{array}$ & & \\
\hline $\begin{array}{l}\text { The enterprise is able to analyze the direct effects from the trade } \\
\text { policies to its activities }\end{array}$ & & \\
\hline $\begin{array}{l}\text { The enterprise is able to analyze the effects from the trade policies } \\
\text { to related industries, which may influence its activities. }\end{array}$ & & \\
\hline $\begin{array}{l}\text { The enterprise is able to analyze the overall effects of the trade } \\
\text { policies. }\end{array}$ & & \\
\hline Others (please specify) & \\
\hline
\end{tabular}

9. The enterprise provides information for the Government making policy process by:

A. Giving comments on drafting legal documents.

B. Discussing in meetings between the Government bodies and enterprises.

C. Participating and discussing in academic seminars/conferences.

D. Sending the comments in documents directly to Government bodies.

E. Sending the comments in documents to Government bodies via Associations of Industries.

F. Others (please specify)

10. After the policy becomes effective and its implementation affects negatively its activities, the enterprise will
A. Not follow the policy's regulations.
B. Adjust its activity alongside with the regulations.
C. Actively send its feedbacks to Government bodies
D. Actively send its feedbacks to Associations of industries.
E. Others (please specify)

11. Challenging barriers that prevent the enterprise to participate more actively to the trade policy formulating and implementing process is/are: 
A. Lack of essential knowledge and understanding of the trade policy process.

B. Thinking that the policy making process is the only concern for the Government bodies.

C. Time constraint.

D. Lack of trade policy related information.

E. Not being informed or not knowing of where/whom to make comments.

F. Not receiving the response from the Government bodies about the previous comments.

G. Others (please specify).

12. Information of the person who conducts the questionnaire:

Full name:

Email address:

Contact number: 


\section{B. For the government bodies}

The Foreign Trade University (Hanoi, Vietnam) is conducting a research on the participation of enterprises in the international trade policy formulation and implementation process. We highly appreciate your time answering our questionnaire.

Please kindly note that the multiple choices in the questionnaire is acceptable.

All the survey results will be released after fully statistically processed.

Please do not hesitate to contact Dr. Dao Ngoc Tien at dntien@ftu.edu.vn or via mobile phone number 0913566677 for detailed information.

\section{Please specify how your government office participates in the policy making process:}
A. to chair the drafting of regulations in your working industry/area.
B. to chair the negotiating with foreign countries.
C. to comment on drafting legal documents/regulations and/or international negotiations.
D. others (please specify)

\section{The reason(s) why enterprises should involve in the trade policy making process is/are}
A. because of the legal regulations.
B. because of the common agreement in the society.
C. to enhance the transparency of the policies
D. to collect the practical information supporting the trade policy making process.
E. to ensure the effectiveness of the policy implementation
F. to support the enterprise's preparation before the policy is implemented
G. others (please specify)

\section{Evaluating the frequency of the organization's consultations in the trade policy formulation in conjunction with other institutes/bodies:}

\begin{tabular}{|l|l|l|l|l|}
\hline \multicolumn{1}{|c|}{ The objective } & None & Occasionally & Usually & Always \\
\hline Other departments in the organization & & & & \\
\hline Related industries and ministries & & & & \\
\hline Institutes run by the managing Ministry & & & & \\
\hline Institutes, Universities & & & & \\
\hline Associations of enterprises & & & & \\
\hline Enterprises & & & & \\
\hline
\end{tabular}




\begin{tabular}{|l|l|l|l|l|}
\hline $\begin{array}{l}\text { Individuals, Researchers, experts, } \\
\text { professors }\end{array}$ & & & & \\
\hline Others (please specify) & & & & \\
\hline
\end{tabular}

4. Evaluating the frequency of the organization's consultations in the trade policy formulation process:

5.

\begin{tabular}{|l|l|l|l|l|}
\hline \multicolumn{1}{|c|}{ The organization } & None & Occasionally & Usually & Always \\
\hline $\begin{array}{l}\text { Sending documents to request } \\
\text { information }\end{array}$ & & & & \\
\hline $\begin{array}{l}\text { Sending questionnaires to } \\
\text { requestinformation }\end{array}$ & & & & \\
\hline $\begin{array}{l}\text { Posting questionnaires publicly on the } \\
\text { organization's official website }\end{array}$ & & & & \\
\hline $\begin{array}{l}\text { Posting the drafting regulations/legal } \\
\text { documents on the organization's official } \\
\text { website }\end{array}$ & & & & \\
\hline Ordering research upon request & & & & \\
\hline Others (please specify) & & & & \\
\hline
\end{tabular}

6. In the policy making process, the organization needs:
A. Statistical data
B. Related regulations and legal documents.
C. Information on enterprises' actual activities.
D. Society's views and comments.
E. Research/Forecast on possible effect of the policy
F. Others (please specify):

6. Evaluating the frequency of the organization to receive information from other actors (when requested) in the policy making process:

\begin{tabular}{|l|l|l|l|l|}
\hline \multicolumn{1}{|c|}{ Organization } & $\begin{array}{c}\text { Not } \\
\text { receiving } \\
\text { any } \\
\text { Information }\end{array}$ & Occasionally & Usually & Always \\
\hline Other departments in the organization & & & & \\
\hline Related industries and ministries & & & & \\
\hline Institutes run by the managing Ministry & & & & \\
\hline Institutes, Universities & & & & \\
\hline Associations of enterprises & & & & \\
\hline
\end{tabular}




\begin{tabular}{|l|l|l|l|l|}
\hline Enterprises & & & & \\
\hline $\begin{array}{l}\text { Individuals, researchers, experts, } \\
\text { professors }\end{array}$ & & & & \\
\hline Others (please specify) & & & & \\
\hline
\end{tabular}




\section{For Associations}

The Foreign Trade University (Hanoi, Vietnam) is conducting a research on the participation of enterprises in the international trade policy formulation and implementation process. We highly appreciate your time answering our questionnaire.

Please kindly note that the multiple choices in the questionnaire is acceptable.

All the survey results will be released after fully statistically processed.

Please do not hesitate to contact Dr. Dao Ngoc Tien at dntien@ftu.edu.vn or via mobile phone number 0913566677 for detailed information.

\section{Name of association:}

2. Information of the association:

- Number of enterprises registered as members in the association:

- Number of staffs/specialists:

- Annual operating budget (million VND/year):

\section{Restrictions on membership:}

A. Types of ownership of enterprises

B. Sector of enterprises

C. Geographical zone of enterprises

D. Others (please specify):

4. Evaluation on the connection of association with government bodies/officials:

\begin{tabular}{|l|l|l|l|}
\hline \multicolumn{1}{|c|}{ Government body } & Not connected & $\begin{array}{c}\text { Modestly } \\
\text { connected }\end{array}$ & $\begin{array}{c}\text { Very frequently } \\
\text { connected }\end{array}$ \\
\hline Ministry of Defense & & & \\
\hline Ministry of Public Security & & & \\
\hline $\begin{array}{l}\text { Ministry of Foreign } \\
\text { Affairs }\end{array}$ & & & \\
\hline Ministry of Justice & & & \\
\hline Ministry of Finance & & & \\
\hline $\begin{array}{l}\text { Ministry of Industry and } \\
\text { Trade }\end{array}$ & & & \\
\hline $\begin{array}{l}\text { Ministry of Labor, Invalids } \\
\text { and Social Affairs }\end{array}$ & & & \\
\hline Ministry of Transportation & & & \\
\hline Ministry of Construction & & & \\
\hline $\begin{array}{l}\text { Ministry of Information } \\
\text { and Communications }\end{array}$ & & & \\
\hline $\begin{array}{l}\text { Ministry of Education and } \\
\text { Training }\end{array}$ & & & \\
\hline
\end{tabular}




\begin{tabular}{|l|l|l|l|}
\hline $\begin{array}{l}\text { Ministry of Agriculture } \\
\text { and Rural development }\end{array}$ & & & \\
\hline $\begin{array}{l}\text { Ministry of Planning and } \\
\text { Investment }\end{array}$ & & & \\
\hline Ministry of Home Affairs & & & \\
\hline Ministry of Health & & & \\
\hline $\begin{array}{l}\text { Ministry of Science and } \\
\text { Technology }\end{array}$ & & & \\
\hline $\begin{array}{l}\text { Ministry of Culture-Sports } \\
\text { and Tourism }\end{array}$ & & & \\
\hline $\begin{array}{l}\text { Ministry of Natural } \\
\text { resource and Environment }\end{array}$ & & & \\
\hline $\begin{array}{l}\text { The State Bank of } \\
\text { Vietnam }\end{array}$ & & & \\
\hline Others (please specify) & & & \\
\hline
\end{tabular}

5. Evaluation the frequency level in collecting members' information through different channels of the association:

\begin{tabular}{|l|l|l|l|l|}
\hline & None & Occasionally & Usually & Always \\
\hline Visits to enterprise members & & & & \\
\hline $\begin{array}{l}\text { Regular meetings with } \\
\text { enterprise members }\end{array}$ & & & & \\
\hline $\begin{array}{l}\text { Annual reports of enterprise } \\
\text { members }\end{array}$ & & & & \\
\hline $\begin{array}{l}\text { Requests from association to } \\
\text { members for information } \\
\text { collection (reports, } \\
\text { questionnaires, etc.) }\end{array}$ & & & & \\
\hline Others (please specify) & & & & \\
\hline
\end{tabular}

6. Evaluation on the frequency of information delivery from the association to associate members

\begin{tabular}{|l|l|l|l|l|}
\hline & None & Occasionally & Usually & Always \\
\hline Visits to enterprise members & & & & \\
\hline $\begin{array}{l}\text { Regular meetings with } \\
\text { enterprise members }\end{array}$ & & & & \\
\hline
\end{tabular}




\begin{tabular}{|l|l|l|l|l|}
\hline $\begin{array}{l}\text { Annual reports of enterprise } \\
\text { members }\end{array}$ & & & & \\
\hline Seminars and conferences & & & & \\
\hline News releases & & & & \\
\hline Updates through websites & & & & \\
\hline Others (please specify) & & & & \\
\hline
\end{tabular}

7. Association learns about the orientation and plan of trade policies formulation through which channel:
A. Meetings with enterprises organized
E. Television, radio channel
by the government agencies
F. Unofficial meetings
B. Scientific seminar/conference
G. Others (please specify)
C. Newspaper, magazine
D. Internet, website

8. Understanding of association on trade policies formulation (please tick $X$ in the appropriate rows)

\begin{tabular}{|l|l|l|}
\hline \multicolumn{1}{|c|}{ Content } & True & False \\
\hline $\begin{array}{l}\text { The association can figure out (without analysis) only the possible } \\
\text { effects from the trade policies }\end{array}$ & & \\
\hline $\begin{array}{l}\text { The association is able to analyze the direct effects from the trade } \\
\text { policies to its activities }\end{array}$ & & \\
\hline $\begin{array}{l}\text { The association is able to analyze the effects from the trade policies } \\
\text { to related industries, which may influence its activities }\end{array}$ & & \\
\hline $\begin{array}{l}\text { The enterprise is able to analyze the overall effects of the trade } \\
\text { policies }\end{array}$ & & \\
\hline Others (please specify) & \\
\hline
\end{tabular}

\section{Association provides information contributing to the government's policy}

\section{formulation through:}
A. Commenting on drafts of legal documents
B. Voicing out ideas in meetings
D. Sending comments in documents directly to government bodies

between the government bodies and enterprises
C. Participating and delivering ideas in scientific seminars/conferences


10. After the policy becomes effective and its implementation affects negatively members' activities, the association will
A. Request its members not to follow the regulations.
B. Consult its members to adjust their activity alongside with the regulations.
C. Actively send feedbacks to Government bodies.
D. Others (please specify)

11. Why associations need to participate in trade policy making process
A. To deliver practical information to the government
B. To build policies appropriate for the development of its industry
C. To contribute to social benefits
D. To increase credibility and position of the association
E. Others (please specify)

12. Obstacles against the participation of the association into the planning and implementing of trade policies is/are:
A. Lack of essential knowledge and understanding.
B. Thinking that the policy making process is the only concern for the Government bodies.
C. Time constraint.
D. Human resource constraint.
E. Budget constraint
F. Lack of information on policies.
G. Lack of interacting channels to deliver comments.
H. Not receiving the response from the Government bodies about the previous comments.
I. Others (please specify).

\section{Information of the person who conducts the questionnaire:}

Full name:

Email address:

Contact number: 
APPENDIX II: Statistical description of variables

\begin{tabular}{|l|l|}
$\mathbf{N}$ & MEAN \\
\hline
\end{tabular}




\begin{tabular}{|c|c|c|c|c|c|c|}
\hline $\begin{array}{l}\text { Headquarter (North) } \\
\text { North }=1 \text { if (the North); North=0 (the South) }\end{array}$ & North & 226 & 0.840708 & 0.3667605 & 0 & 1 \\
\hline $\begin{array}{l}\text { Ownership (owners } \sim p \text { ) } \\
\text { owners } \sim p=1 \text { (the state-owned enterprises) } \\
\text { owners } \sim p=2 \text { (the private enterprises) } \\
\text { owners } \sim p=3 \text { (the FDI enterprises) }\end{array}$ & owners $\sim p$ & 219 & 2.041096 & 0.6927877 & 1 & 3 \\
\hline $\begin{array}{l}\text { Enterprises join to provide information ( q_9_1) } \\
\text { q_9_1=1 (yes) } \\
\text { q_9_1=0 (no) }\end{array}$ & q_9_1 & 226 & 0.1769912 & 0.3825084 & 0 & 1 \\
\hline $\begin{array}{l}\text { Enterprises join for their own benefit } \\
\text { q_9_2 }=1 \text { (yes) } \\
\text { q_9_2 }=0 \text { (no) }\end{array}$ & q_9_2 & 226 & 0.5884956 & 0.4931986 & 0 & 1 \\
\hline $\begin{array}{l}\text { Enterprises join for the whole industry } \\
\text { q_9_3 }=1 \text { (yes) } \\
\text { q_9_3 =0 (no) }\end{array}$ & q_9__3 & 226 & 0.4159292 & 0.4939755 & 0 & 1 \\
\hline $\begin{array}{l}\text { Negotiaton preparation } \\
\text { q0010_ 1=1 (unnecessary) } \\
\text { q0010_ 1=2 (necessary but unimportant) } \\
\text { q0010_ 1=3 (important) } \\
\text { q0010_ 1=4 (Very important) }\end{array}$ & q0010_ 1 & 115 & 2.530435 & 0.9940325 & 1 & 4 \\
\hline $\begin{array}{l}\text { In the process of negotiation } \\
\text { q0010_ 2=1 (unnecessary) } \\
\text { q0010_ 2=2 (necessary but unimportant) } \\
\text { q0010_ 2=3 (important) } \\
\text { q0010_ 2=4 (Very important) }\end{array}$ & q0010_ 2 & 110 & 2.509091 & 1.064398 & 1 & 4 \\
\hline $\begin{array}{l}\text { Approval of agreements preparation } \\
\text { q0010_ 3=1 (unnecessary) }\end{array}$ & q0010_ 3 & 107 & 2.401869 & 1.008079 & 1 & 4 \\
\hline
\end{tabular}




\begin{tabular}{|c|c|c|c|c|c|c|}
\hline $\begin{array}{l}\text { q0010_ 3=2 (necessary but unimportant) } \\
\text { q0010_ 3=3 (important) } \\
\text { q0010_ 3=4 (Very important) }\end{array}$ & & & & & & \\
\hline $\begin{array}{l}\text { Policy draft } \\
\text { q0010_ 4=1 (unnecessary) } \\
\text { q0010_ 4=2 (necessary but unimportant) } \\
\text { q0010_ 4=3 (important) } \\
\text { q0010_ 4=4 (Very important) }\end{array}$ & q0010_ 4 & 112 & 2.866071 & 0.8328345 & 1 & 4 \\
\hline $\begin{array}{l}\text { Policy launching preparation } \\
\text { q0010_ 5=1 (unnecessary) } \\
\text { q0010_ 5=2 (necessary but unimportant) } \\
\text { q0010_ 5=3 (important) } \\
\text { q0010_ 5=4 (Very important) }\end{array}$ & q0010_ 5 & 110 & 2.890909 & 0.8603973 & 1 & 4 \\
\hline $\begin{array}{l}\text { Policy Implementation } \\
\text { q0010_ 6=1 (unnecessary) } \\
\text { q0010_ 6=2 (necessary but unimportant) } \\
\text { q0010_ 6=3 (important) } \\
\text { q0010_ 6=4 (Very important) }\end{array}$ & q0010_ 6 & 104 & 3.230769 & 0.8387551 & 1 & 4 \\
\hline $\begin{array}{l}\text { Enterprise's policy participation via VCCI } \\
\text { q0011_ 1=1 (unnecessary) } \\
\text { q0011_ 1=2 (necessary but unimportant) } \\
\text { q0011_ 1=3 (important) } \\
\text { q0011_ 1=4 (Very important) }\end{array}$ & q0011_ 1 & 113 & 2.539823 & 0.9823023 & 1 & 4 \\
\hline $\begin{array}{l}\text { Enterprise's policy participation via associ } \\
\text { q0011_ 2=1 (unnecessary) } \\
\text { q0011_ 2=2 (necessary but unimportant) } \\
\text { q0011_ } 2=3 \text { (important) } \\
\text { q0011_ 2=4 (Very important) }\end{array}$ & q0011_ 2 & 118 & 2.694915 & 1.008583 & 1 & 4 \\
\hline
\end{tabular}




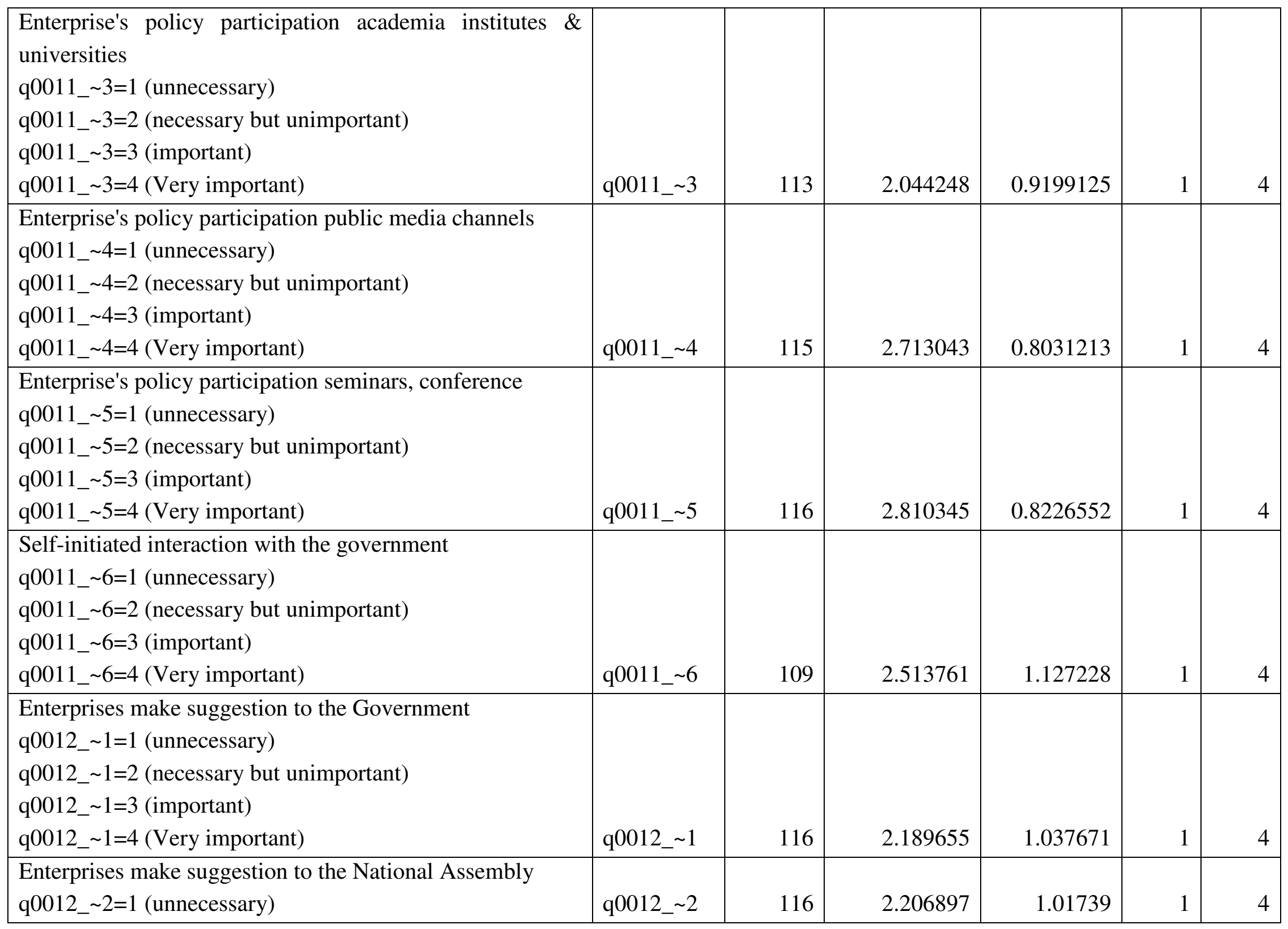




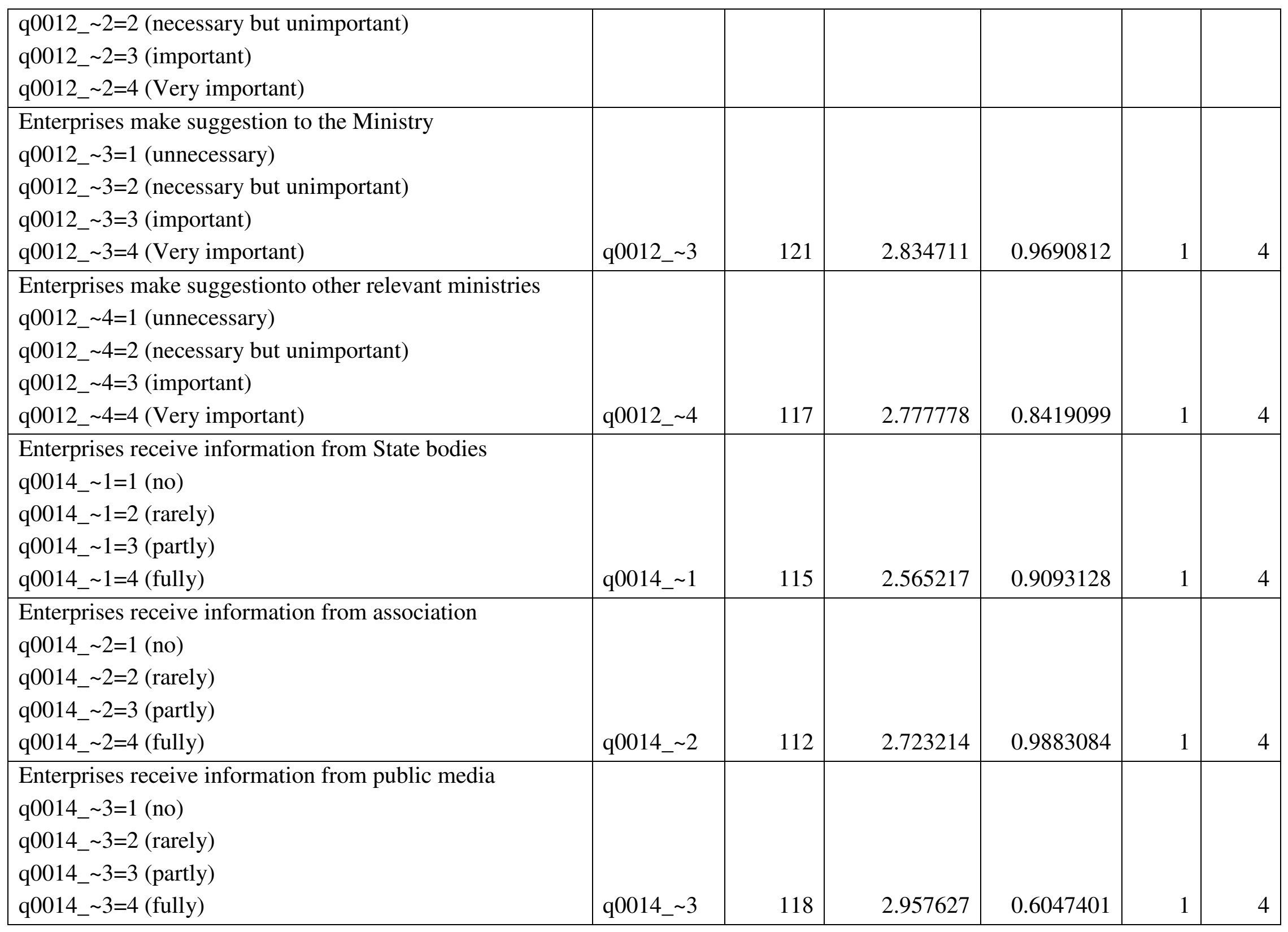




\begin{tabular}{|c|c|c|c|c|c|c|}
\hline $\begin{array}{l}\text { Enterprises get information via meeting with the } \\
\text { Government } \\
\text { q_13_1=1 (yes) } \\
\text { q_13_1=0 (no) }\end{array}$ & q_13_1 & 226 & 0.3141593 & 0.4652105 & 0 & 1 \\
\hline $\begin{array}{l}\text { Enterprises get information via conferences/seminars } \\
\text { q_13_2=1 (yes) } \\
\text { q_13_2=0 (no) }\end{array}$ & q_13_2 & 226 & 0.2433628 & 0.4300648 & 0 & 1 \\
\hline $\begin{array}{l}\text { Enterprises get information via association } \\
\text { q_13_3=1 (yes) } \\
\text { q_13_3 }=0 \text { (no) }\end{array}$ & q_13_3 & 226 & 0.3672566 & 0.4831273 & 0 & 1 \\
\hline $\begin{array}{l}\text { Enterprises get information via journals } \\
\text { q_13_4=1 (yes) } \\
\text { q_13_4=0 (no) }\end{array}$ & q_13_4 & 226 & 0.4070796 & 0.4923805 & 0 & 1 \\
\hline $\begin{array}{l}\text { Enterprises get information via internet, websites } \\
\text { q_13_5=1 (yes) } \\
\text { q_13_5=0 (no) }\end{array}$ & q_13_5 & 226 & 0.5707965 & 0.4960612 & 0 & 1 \\
\hline $\begin{array}{l}\text { Enterprises get information via public media } \\
\text { q_13_6=1 (yes) } \\
\text { q_13_6=0 (no) }\end{array}$ & q_13_6 & 226 & 0.3938053 & 0.4896771 & 0 & 1 \\
\hline $\begin{array}{l}\text { Enterprises get information via direct talk } \\
\text { q_13_7=1 (yes) } \\
\text { q_13_7 }=0 \text { (no) }\end{array}$ & q_13_7 & 226 & 0.1017699 & 0.3030166 & 0 & 1 \\
\hline $\begin{array}{l}\text { Enterprises get information via unofficial meeting } \\
\text { q_13_8=1 (yes) } \\
\text { q_13_8=0 (no) }\end{array}$ & q_13_8 & 226 & 0.1017699 & 0.3030166 & 0 & 1 \\
\hline $\begin{array}{l}\text { Enterprises can figure out (without analysis) the possible } \\
\text { effects from the trade policies }\end{array}$ & q_15_1 & 226 & 0.4469027 & 0.4982763 & 0 & 1 \\
\hline
\end{tabular}




\begin{tabular}{|c|c|c|c|c|c|c|}
\hline $\begin{array}{l}\text { q_15_1=1 (right) } \\
\text { q_15_1 }=0 \text { (wrong) }\end{array}$ & & & & & & \\
\hline $\begin{array}{l}\text { Enterprises can analyze the direct effects from the trade } \\
\text { policies to its activities } \\
\text { q_15_2=1 (right) } \\
\text { q_15_2 }=0 \text { (wrong) }\end{array}$ & q_15_2 & 226 & 0.6238938 & 0.4854825 & 0 & 1 \\
\hline $\begin{array}{l}\text { Enterprises can analyze the effects from the trade policies } \\
\text { to related industries, which may influence its activities. } \\
\text { q_15_3=1 (right) } \\
\text { q_15_3 }=0 \text { (wrong) }\end{array}$ & q_15_3 & 226 & 0.5619469 & 0.4972491 & 0 & 1 \\
\hline $\begin{array}{l}\text { Enterprises can analyze the overall effects of the trade } \\
\text { policies. } \\
\text { q_15_4=1 (right) } \\
\text { q_15_4 }=0 \text { (wrong) }\end{array}$ & q_15_4 & 226 & 0.4070796 & 0.4923805 & 0 & 1 \\
\hline $\begin{array}{l}\text { Enterprises provide information by make suggestion to the } \\
\text { draft of policy } \\
\text { q_16_1=1 (yes) } \\
\text { q_16_1 }=0 \text { (no) }\end{array}$ & q_16_1 & 226 & 0.2168142 & 0.4129897 & 0 & 1 \\
\hline $\begin{array}{l}\text { Enterprises provide information by sending idea at the } \\
\text { meeting } \\
\text { q_16_2=1(yes) } \\
\text { q_16_2 }=0 \text { (no) }\end{array}$ & q_16_2 & 226 & 0.380531 & 0.4865951 & 0 & 1 \\
\hline $\begin{array}{l}\text { Enterprises provide information by sending idea at } \\
\text { conference/seminar } \\
\text { q_16_3=1 (yes) } \\
\text { q_16_3 }=0 \text { (no) }\end{array}$ & q_16_3 & 226 & 0.2654867 & 0.4425723 & 0 & 1 \\
\hline
\end{tabular}




\begin{tabular}{|c|c|c|c|c|c|c|}
\hline $\begin{array}{l}\text { Enterprises provide information by directly sending idea to } \\
\text { the state bodies } \\
\text { q_16_4=1 (yes) } \\
\text { q_16_4=0 (no) }\end{array}$ & q_16_4 & 226 & 0.1946903 & 0.396841 & 0 & 1 \\
\hline $\begin{array}{l}\text { Enterprises do not follow the policy's regulations } \\
\text { q_17_1=1 (yes) } \\
\text { q_17_1 }=0 \text { (no) }\end{array}$ & q_17_1 & 226 & 0.0132743 & 0.1147011 & 0 & 1 \\
\hline $\begin{array}{l}\text { Enterprises adjust their activities alongside to the policy } \\
\text { q_17_2=1 (yes) } \\
\text { q_17_2=0 (no) }\end{array}$ & q_17_2 & 226 & 0.5 & 0.5011099 & 0 & 1 \\
\hline $\begin{array}{l}\text { Enterprises actively send feedbacks to the State bodies } \\
\text { q_17_3=1 (yes) } \\
\text { q_17_3 }=0 \text { (no) }\end{array}$ & q_17_3 & 226 & 0.2699115 & 0.444899 & 0 & 1 \\
\hline $\begin{array}{l}\text { Enterprises actively send feedbacks to business } \\
\text { associations } \\
\text { q_17_4=1 (yes) } \\
\text { q_17_4=0 (no) }\end{array}$ & q_17_4 & 226 & 0.3672566 & 0.4831273 & 0 & 1 \\
\hline $\begin{array}{l}\text { Enterprises lack of essential knowledge } \\
\text { q_18_1=1 (yes) } \\
\text { q_18_1 }=0 \text { (no) }\end{array}$ & q_18_1 & 226 & 0.2610619 & 0.4401886 & 0 & 1 \\
\hline $\begin{array}{l}\text { Policy belong to the Government's concern } \\
\text { q_18_2=1 (yes) } \\
\text { q_18_2=0 (no) }\end{array}$ & q_18_2 & 226 & 0.1150442 & 0.3197836 & 0 & 1 \\
\hline $\begin{array}{l}\text { Enterprises suffer time constraint } \\
\text { q_18_3=1 (yes) } \\
\text { q_18_3=0(no) }\end{array}$ & q_18_3 & 226 & 0.0752212 & 0.2643335 & 0 & 1 \\
\hline Enterprises do not have trade related information & q_18_4 & 226 & 0.3230088 & 0.4686641 & 0 & 1 \\
\hline
\end{tabular}




\begin{tabular}{|l|l|r|r|r|r|}
\hline $\begin{array}{l}\text { q_18_4=1 (yes) } \\
\text { q_18_4=0 (no) }\end{array}$ & & & \\
\hline $\begin{array}{l}\text { Enterprises do not have channels for comments } \\
\text { q_18_5=1 (yes) } \\
\text { q_18_5=0 (no) }\end{array}$ & & & \\
\hline $\begin{array}{l}\text { Enterprises do not receive the feedbacks from the } \\
\text { Government bodies on previous comments } \\
\text { q_18_6=1 (yes) } \\
\text { q_18_6=0 (no) }\end{array}$ & q_18_6 & 226 & 0.3318584 & 0.4719257 & 0 \\
\hline
\end{tabular}


APPENDIX III: Statistical test of differences by Headquarter's location

\begin{tabular}{|c|c|c|c|c|c|c|c|c|c|c|c|c|}
\hline \multirow[b]{2}{*}{ VARIABLE } & \multicolumn{5}{|c|}{ THE SOUTH } & \multicolumn{5}{|c|}{ THE NORTH } & \multirow[b]{2}{*}{ P-VALUE } & \multirow[b]{2}{*}{ DIFF } \\
\hline & $\mathbf{N}$ & MEAN & SD & MIN & MAX & $\mathbf{N}$ & MEAN & SD & MIN & \begin{tabular}{|l|} 
MA \\
$\mathbf{X}$ \\
\end{tabular} & & \\
\hline & & 0.22222 & & & & & 0.16842 & & & & 0.47888129 & \\
\hline q_9_1 & 36 & 2 & 0.421637 & 0 & 1 & 190 & 1 & 0.375 & 0 & 1 & 9 & 0.053 \\
\hline & & 0.44444 & & & & & 0.61578 & & & & 0.06615088 & \\
\hline q_9_2 & 36 & 4 & 0.503953 & 0 & 1 & 190 & 9 & 0.488 & 0 & 1 & 1 & $-0.171^{*}$ \\
\hline & & 0.33333 & & & & & 0.43157 & & & & 0.26656186 & \\
\hline q_9_3 & 36 & 3 & 0.478091 & 0 & 1 & 190 & 9 & 0.497 & 0 & 1 & 6 & -0.098 \\
\hline q0010_0001 & 22 & $\begin{array}{r}3.27272 \\
7\end{array}$ & 0.827032 & 1 & 4 & 93 & $\begin{array}{r}2.35483 \\
9\end{array}$ & 0.951 & 1 & 4 & $\begin{array}{r}6.19568 \mathrm{E}- \\
05\end{array}$ & $0.917 *$ \\
\hline q0010_0002 & 22 & $\begin{array}{r}2.81818 \\
2\end{array}$ & 1.006473 & 1 & 4 & 88 & $\begin{array}{r}2.43181 \\
8\end{array}$ & 1.07 & 1 & 4 & $\begin{array}{r}0.12114013 \\
7\end{array}$ & 0.386 \\
\hline q0010_0003 & 22 & $\begin{array}{r}2.59090 \\
9 \\
\end{array}$ & 0.908116 & 1 & 4 & 85 & $\begin{array}{r}2.35294 \\
1 \\
\end{array}$ & 1.032 & 1 & 4 & $\begin{array}{r}0.29428115 \\
5 \\
\end{array}$ & 0.237 \\
\hline q0010_0004 & 22 & $\begin{array}{r}3.27272 \\
7\end{array}$ & 0.7025 & 2 & 4 & 90 & $\begin{array}{r}2.76666 \\
7\end{array}$ & 0.835 & 1 & 4 & $\begin{array}{r}0.00604292 \\
4\end{array}$ & $0.506 *$ \\
\hline q0010_0005 & 22 & $\begin{array}{r}3.18181 \\
8 \\
\end{array}$ & 0.664499 & 2 & 4 & 88 & $\begin{array}{r}2.81818 \\
2 \\
\end{array}$ & 0.891 & 1 & 4 & $\begin{array}{r}0.03890182 \\
8 \\
\end{array}$ & $0.363 *$ \\
\hline q0010_0006 & 22 & $\begin{array}{r}3.63636 \\
4\end{array}$ & 0.492366 & 3 & 4 & 82 & $\begin{array}{r}3.12195 \\
1 \\
\end{array}$ & 0.88 & 1 & 4 & $\begin{array}{r}0.00064991 \\
2 \\
\end{array}$ & $0.514 *$ \\
\hline q0011_0001 & 22 & 3 & 0.816497 & 1 & 4 & 91 & $\begin{array}{r}2.42857 \\
1 \\
\end{array}$ & 0.99 & 1 & 4 & $\begin{array}{r}0.00764609 \\
8 \\
\end{array}$ & $0.571^{*}$ \\
\hline
\end{tabular}




\begin{tabular}{|c|c|c|c|c|c|c|c|c|c|c|c|c|}
\hline q0011_0002 & 23 & $\begin{array}{r}3.04347 \\
8\end{array}$ & 0.877924 & 1 & 4 & 95 & $\begin{array}{r}2.61052 \\
6\end{array}$ & 1.024 & 1 & 4 & $\begin{array}{r}0.04720148 \\
1\end{array}$ & $0.432 *$ \\
\hline q0011_0003 & 22 & $\begin{array}{r}2.54545 \\
5\end{array}$ & 0.800433 & 1 & 4 & 91 & $\begin{array}{r}1.92307 \\
7\end{array}$ & 0.91 & 1 & 4 & $\begin{array}{r}0.00302901 \\
5\end{array}$ & $0.622 *$ \\
\hline q0011_0004 & 21 & $\begin{array}{r}3.04761 \\
9\end{array}$ & 0.804748 & 2 & 4 & 94 & $\begin{array}{r}2.63829 \\
8\end{array}$ & 0.788 & 1 & 4 & $\begin{array}{r}0.04304497 \\
3\end{array}$ & $0.409 *$ \\
\hline q0011_0005 & 22 & $\begin{array}{r}3.22727 \\
3\end{array}$ & 0.685344 & 2 & 4 & 94 & $\begin{array}{r}2.71276 \\
6\end{array}$ & 0.825 & 1 & 4 & $\begin{array}{r}0.00431043 \\
9\end{array}$ & $0.514 *$ \\
\hline q0011_0006 & 23 & 3 & 1 & 1 & 4 & 86 & $\begin{array}{r}2.38372 \\
1\end{array}$ & 1.129 & 1 & 4 & $\begin{array}{r}0.01479448 \\
8\end{array}$ & $0.616^{*}$ \\
\hline q0012_0001 & 22 & $\begin{array}{r}2.59090 \\
9\end{array}$ & 1.007547 & 1 & 4 & 94 & $\begin{array}{r}2.09574 \\
5\end{array}$ & 1.027 & 1 & 4 & $\begin{array}{r}0.04686206 \\
6\end{array}$ & $0.495 *$ \\
\hline q0012_0002 & 22 & $\begin{array}{r}2.81818 \\
2\end{array}$ & 1.006473 & 1 & 4 & 94 & 2.06383 & 0.971 & 1 & 4 & $\begin{array}{r}0.00329778 \\
3\end{array}$ & $0.754^{*}$ \\
\hline q0012_0003 & 22 & $\begin{array}{r}3.13636 \\
4\end{array}$ & 0.990212 & 1 & 4 & 99 & $\begin{array}{r}2.76767 \\
7\end{array}$ & 0.956 & 1 & 4 & $\begin{array}{r}0.12234688 \\
6\end{array}$ & 0.368 \\
\hline q0012_0004 & 23 & $\begin{array}{r}2.91304 \\
3\end{array}$ & 0.900154 & 1 & 4 & 94 & $\begin{array}{r}2.74468 \\
1\end{array}$ & 0.829 & 1 & 4 & $\begin{array}{r}0.42039173 \\
8\end{array}$ & 0.168 \\
\hline q0014_0001 & 23 & $\begin{array}{r}2.69565 \\
2\end{array}$ & 0.926125 & 1 & 4 & 92 & $\begin{array}{r}2.53260 \\
9\end{array}$ & 0.907 & 1 & 4 & $\begin{array}{r}0.45363596 \\
1\end{array}$ & 0.163 \\
\hline q0014_0002 & 23 & $\begin{array}{r}2.78260 \\
9\end{array}$ & 0.902347 & 1 & 4 & 89 & $\begin{array}{r}2.70786 \\
5\end{array}$ & 1.014 & 1 & 4 & $\begin{array}{r}0.73203432 \\
6\end{array}$ & 0.074 \\
\hline q0014_0003 & 24 & 2.75 & 0.442326 & 2 & 3 & 94 & $\begin{array}{r}3.01063 \\
8\end{array}$ & 0.631 & 1 & 4 & $\begin{array}{r}0.02321540 \\
8\end{array}$ & $-0.260 *$ \\
\hline q_13_1 & 36 & 0.19444 & 0.401386 & 0 & 1 & 190 & 0.33684 & 0.474 & 0 & 1 & 0.06357349 & $-0.142 *$ \\
\hline
\end{tabular}




\begin{tabular}{|c|c|c|c|c|c|c|c|c|c|c|c|c|}
\hline & & 4 & & & & & 2 & & & & 5 & \\
\hline & & 0.30555 & & & & & 0.23157 & & & & 0.38128194 & \\
\hline q_13_2 & 36 & 6 & 0.467177 & 0 & 1 & 190 & 9 & 0.423 & 0 & 1 & 2 & 0.073 \\
\hline & & 0.36111 & & & & & 0.36842 & & & & 0.93446844 & \\
\hline q_13_3 & 36 & 1 & 0.487136 & 0 & 1 & 190 & 1 & 0.484 & 0 & 1 & 8 & -0.007 \\
\hline q_13_4 & 36 & $\begin{array}{r}0.36111 \\
1\end{array}$ & 0.487136 & 0 & 1 & 190 & $\begin{array}{r}0.41578 \\
9\end{array}$ & 0.494 & 0 & 1 & 0.54065764 & -0.054 \\
\hline q_13_5 & 36 & $\begin{array}{r}0.44444 \\
4\end{array}$ & 0.503953 & 0 & 1 & 190 & $\begin{array}{r}0.59473 \\
7\end{array}$ & 0.492 & 0 & 1 & $\begin{array}{r}0.10608329 \\
6\end{array}$ & -0.150 \\
\hline q_13_6 & 36 & 0.25 & 0.439155 & 0 & 1 & 190 & $\begin{array}{r}0.42105 \\
3\end{array}$ & 0.495 & 0 & 1 & 0.04065454 & $-0.171^{*}$ \\
\hline q_13_7 & 36 & $\begin{array}{r}0.11111 \\
1\end{array}$ & 0.318728 & 0 & 1 & 190 & 0.1 & 0.301 & 0 & 1 & $\begin{array}{r}0.84740978 \\
5\end{array}$ & 0.011 \\
\hline q_13_8 & 36 & $\begin{array}{r}0.08333 \\
3\end{array}$ & 0.280306 & 0 & 1 & 190 & $\begin{array}{r}0.10526 \\
3\end{array}$ & 0.308 & 0 & 1 & $\begin{array}{r}0.67363554 \\
2\end{array}$ & -0.021 \\
\hline q_15_1 & 36 & $\begin{array}{r}0.41666 \\
7 \\
\end{array}$ & 0.5 & 0 & 1 & 190 & $\begin{array}{r}0.45263 \\
2 \\
\end{array}$ & 0.499 & 0 & 1 & $\begin{array}{r}0.69394183 \\
2 \\
\end{array}$ & -0.035 \\
\hline q_15_2 & 36 & $\begin{array}{r}0.38888 \\
9\end{array}$ & 0.494413 & 0 & 1 & 190 & $\begin{array}{r}0.66842 \\
1\end{array}$ & 0.472 & 0 & 1 & $\begin{array}{r}0.00295491 \\
7\end{array}$ & $-0.279 *$ \\
\hline q_15_3 & 36 & $\begin{array}{r}0.47222 \\
2\end{array}$ & 0.506309 & 0 & 1 & 190 & $\begin{array}{r}0.57894 \\
7\end{array}$ & 0.495 & 0 & 1 & $\begin{array}{r}0.25022137 \\
2\end{array}$ & -0.106 \\
\hline q_15_4 & 36 & $\begin{array}{r}0.36111 \\
1\end{array}$ & 0.487136 & 0 & 1 & 190 & $\begin{array}{r}0.41578 \\
9\end{array}$ & 0.494 & 0 & 1 & 0.54065764 & -0.054 \\
\hline q_16_1 & 36 & $\begin{array}{r}0.22222 \\
2\end{array}$ & 0.421637 & 0 & 1 & 190 & $\begin{array}{r}0.21578 \\
9\end{array}$ & 0.412 & 0 & 1 & $\begin{array}{r}0.93322610 \\
9\end{array}$ & 0.006 \\
\hline
\end{tabular}




\begin{tabular}{|c|c|c|c|c|c|c|c|c|c|c|c|c|}
\hline \multirow[b]{2}{*}{ q_16_2 } & \multirow[b]{2}{*}{36} & \multirow{2}{*}{$\begin{array}{r}0.33333 \\
3\end{array}$} & \multirow[b]{2}{*}{0.478091} & \multirow[b]{2}{*}{0} & \multirow[b]{2}{*}{1} & \multirow[b]{2}{*}{190} & \multirow{2}{*}{$\begin{array}{r}0.38947 \\
4\end{array}$} & \multirow[b]{2}{*}{0.489} & \multirow[b]{2}{*}{0} & \multicolumn{2}{|r|}{0.52274179} & \multirow[b]{2}{*}{-0.056} \\
\hline & & & & & & & & & & 1 & 5 & \\
\hline \multirow[b]{2}{*}{ q_16_3 } & & 0.36111 & & & & & 0.24736 & & & & 0.19779720 & \\
\hline & 36 & 1 & 0.487136 & 0 & 1 & 190 & 8 & 0.433 & 0 & 1 & 9 & 0.113 \\
\hline \multirow[b]{2}{*}{ q_16_4 } & & 0.11111 & & & & & 0.21052 & & & & 0.10755030 & \\
\hline & 36 & 1 & 0.318728 & 0 & 1 & 190 & 6 & 0.409 & 0 & 1 & 8 & -0.099 \\
\hline \multirow{2}{*}{ q_17_1 } & & & & & & & 0.01578 & & & & 0.08326017 & \\
\hline & 36 & 0 & 0 & 0 & 0 & 190 & 9 & 0.125 & 0 & 1 & 9 & $-0.015^{*}$ \\
\hline \multirow{2}{*}{ q_17_2 } & & 0.55555 & & & & & 0.48947 & & & & 0.47371888 & \\
\hline & 36 & 6 & 0.503953 & 0 & 1 & 190 & 4 & 0.501 & 0 & 1 & 2 & 0.066 \\
\hline \multirow{2}{*}{ q_17_3 } & & 0.19444 & & & & & 0.28421 & & & & 0.23361991 & \\
\hline & 36 & 4 & 0.401386 & 0 & 1 & 190 & 1 & 0.452 & 0 & 1 & 3 & -0.089 \\
\hline \multirow[b]{2}{*}{ q_17_4 } & & 0.36111 & & & & & 0.36842 & & & & 0.93446844 & \\
\hline & 36 & 1 & 0.487136 & 0 & 1 & 190 & 1 & 0.484 & 0 & 1 & 8 & -0.007 \\
\hline \multirow[b]{2}{*}{ q_18_1 } & & 0.11111 & & & & & 0.28947 & & & & 0.00580256 & \\
\hline & 36 & 1 & 0.318728 & 0 & 1 & 190 & 4 & 0.455 & 0 & 1 & 7 & $-0.178 *$ \\
\hline \multirow[b]{2}{*}{$\mathrm{q}+18 \_2$} & & 0.11111 & & & & & 0.11578 & & & & & \\
\hline & 36 & 1 & 0.318728 & 0 & 1 & 190 & 9 & 0.321 & 0 & 1 & 0.93603313 & -0.004 \\
\hline \multirow[b]{2}{*}{ q_18_3 } & & 0.13888 & & & & & 0.06315 & & & & 0.22193047 & \\
\hline & 36 & 9 & 0.350736 & 0 & 1 & 190 & 8 & 0.244 & 0 & 1 & 4 & 0.075 \\
\hline \multirow[b]{2}{*}{ q_18_4 } & & 0.41666 & & & & & 0.30526 & & & & 0.22099153 & \\
\hline & 36 & 7 & 0.5 & 0 & 1 & 190 & 3 & 0.462 & 0 & 1 & 7 & 0.111 \\
\hline & & 0.41666 & & & & & 0.31578 & & & & 0.26765459 & \\
\hline q_18_5 & 36 & 7 & 0.5 & 0 & 1 & 190 & 9 & 0.466 & 0 & 1 & 8 & 0.100 \\
\hline q_18_6 & 36 & 0.33333 & 0.478091 & 0 & 1 & 190 & 0.24210 & 0.429 & 0 & 1 & 0.29182323 & 0.091 \\
\hline
\end{tabular}




\begin{tabular}{|l|l|l|l|l|l|l|l|l|l|l|l|}
\hline & 3 & & & & & 5 & & & & 8 & \\
\hline
\end{tabular}


APPENDIX IV: Statistical test of differences by State-investment

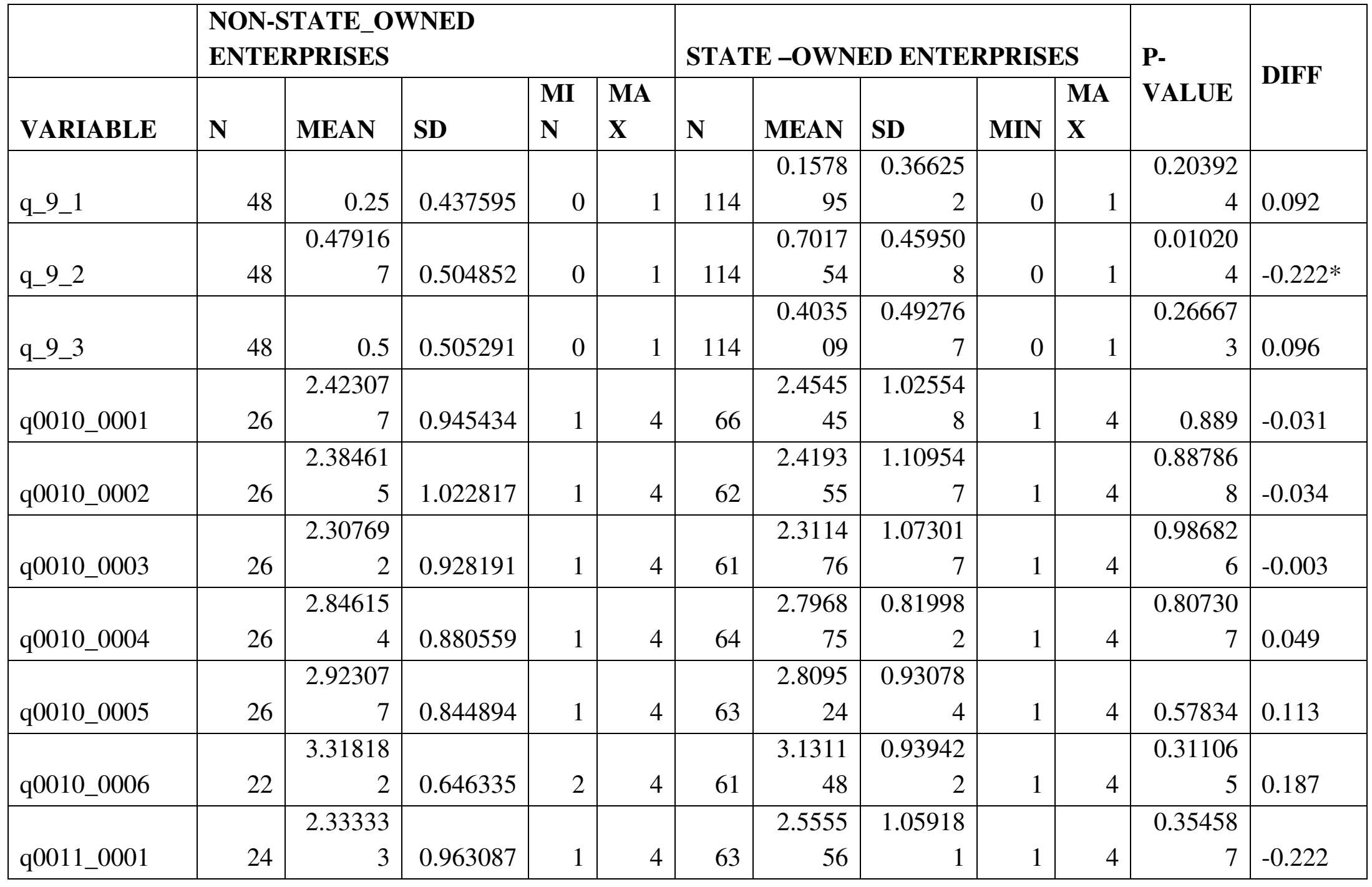




\begin{tabular}{|c|c|c|c|c|c|c|c|c|c|c|c|c|}
\hline q0011_0002 & 25 & 2.6 & 1 & 1 & 4 & 69 & $\begin{array}{r}2.6376 \\
81\end{array}$ & $\begin{array}{r}1.01417 \\
9\end{array}$ & 1 & 4 & $\begin{array}{r}0.87299 \\
5\end{array}$ & -0.037 \\
\hline q0011_0003 & 25 & 2.12 & 1.053565 & 1 & 4 & 64 & $\begin{array}{r}2.0156 \\
25\end{array}$ & $\begin{array}{r}0.88177 \\
6\end{array}$ & 1 & 4 & $\begin{array}{r}0.66321 \\
6\end{array}$ & 0.104 \\
\hline q0011_0004 & 24 & 2.5 & 0.722315 & 1 & 4 & 67 & $\begin{array}{r}2.7910 \\
45\end{array}$ & $\begin{array}{r}0.84454 \\
2\end{array}$ & 1 & 4 & $\begin{array}{r}0.11249 \\
2\end{array}$ & -0.291 \\
\hline q0011_0005 & 26 & $\begin{array}{r}2.73076 \\
9\end{array}$ & 0.77757 & 1 & 4 & 67 & $\begin{array}{r}2.8656 \\
72\end{array}$ & $\begin{array}{r}0.85094 \\
5\end{array}$ & 1 & 4 & $\begin{array}{r}0.46825 \\
3\end{array}$ & -0.134 \\
\hline q0011_0006 & 23 & $\begin{array}{r}2.86956 \\
5\end{array}$ & 1.01374 & 1 & 4 & 64 & $\begin{array}{r}2.3281 \\
25\end{array}$ & $\begin{array}{r}1.12764 \\
2\end{array}$ & 1 & 4 & $\begin{array}{r}0.03884 \\
5\end{array}$ & $0.541 *$ \\
\hline q0012_0001 & 25 & 2.68 & 1.029563 & 1 & 4 & 66 & $\begin{array}{r}1.9696 \\
97\end{array}$ & $\begin{array}{r}0.97617 \\
3\end{array}$ & 1 & 4 & $\begin{array}{r}0.00481 \\
8\end{array}$ & $0.710 *$ \\
\hline q0012_0002 & 25 & 2.48 & 0.962635 & 1 & 4 & 66 & $\begin{array}{r}2.0757 \\
58\end{array}$ & $\begin{array}{r}1.04234 \\
4\end{array}$ & 1 & 4 & $\begin{array}{r}0.08717 \\
8\end{array}$ & $0.404 *$ \\
\hline q0012_0003 & 26 & $\begin{array}{r}3.03846 \\
1\end{array}$ & 0.958364 & 1 & 4 & 68 & 2.75 & $\begin{array}{r}0.96776 \\
4\end{array}$ & 1 & 4 & $\begin{array}{r}0.19949 \\
9\end{array}$ & 0.288 \\
\hline q0012_0004 & 25 & 2.84 & 0.8 & 1 & 4 & 68 & $\begin{array}{r}2.7647 \\
06\end{array}$ & $\begin{array}{r}0.86589 \\
9\end{array}$ & 1 & 4 & $\begin{array}{r}0.69581 \\
8\end{array}$ & 0.075 \\
\hline q0014_0001 & 25 & 2.8 & 0.763763 & 1 & 4 & 66 & $\begin{array}{r}2.4242 \\
42\end{array}$ & $\begin{array}{r}0.92919 \\
5\end{array}$ & 1 & 4 & $\begin{array}{r}0.05424 \\
3\end{array}$ & $0.375^{*}$ \\
\hline q0014_0002 & 23 & 3 & 0.6742 & 1 & 4 & 64 & 2.5625 & $\begin{array}{r}1.03701 \\
3\end{array}$ & 1 & 4 & $\begin{array}{r}0.02567 \\
4\end{array}$ & $0.437 *$ \\
\hline q0014_0003 & 23 & $\begin{array}{r}3.21739 \\
1\end{array}$ & 0.518435 & 2 & 4 & 70 & $\begin{array}{r}2.9428 \\
57\end{array}$ & $\begin{array}{r}0.58695 \\
3\end{array}$ & 1 & 4 & $\begin{array}{r}0.03903 \\
8\end{array}$ & $0.274 *$ \\
\hline q_13_1 & 48 & 0.33333 & 0.476393 & 0 & 1 & 114 & 0.3157 & 0.46688 & 0 & 1 & 0.83004 & 0.017 \\
\hline
\end{tabular}




\begin{tabular}{|c|c|c|c|c|c|c|c|c|c|c|c|c|}
\hline & & 3 & & & & & 89 & 2 & & & 2 & \\
\hline \multirow[b]{2}{*}{ q_13_2 } & & 0.29166 & & & & & 0.2280 & 0.42144 & & & 0.41221 & \\
\hline & 48 & 7 & 0.45934 & 0 & 1 & 114 & 7 & 1 & 0 & 1 & 1 & 0.063 \\
\hline \multirow[b]{2}{*}{ q_13_3 } & & & & & & & 0.4122 & 0.49441 & & & 0.22645 & \\
\hline & 48 & 0.3125 & 0.468417 & 0 & 1 & 114 & 81 & 8 & 0 & 1 & 4 & -0.099 \\
\hline \multirow[b]{2}{*}{ q_13_4 } & & 0.41666 & & & & & 0.4736 & 0.50151 & & & 0.50852 & \\
\hline & 48 & 7 & 0.498224 & 0 & 1 & 114 & 84 & 1 & 0 & 1 & 4 & -0.057 \\
\hline \multirow[b]{2}{*}{ q_13_5 } & & 0.58333 & & & & & 0.6666 & 0.47348 & & & 0.32677 & \\
\hline & 48 & 3 & 0.498224 & 0 & 1 & 114 & 67 & 6 & 0 & 1 & 8 & -0.083 \\
\hline \multirow[b]{2}{*}{ q_13_6 } & & 0.45833 & & & & & 0.4122 & 0.49441 & & & 0.59443 & \\
\hline & 48 & 3 & 0.503534 & 0 & 1 & 114 & 81 & 8 & 0 & 1 & 2 & 0.046 \\
\hline \multirow[b]{2}{*}{ q_13_7 } & & & & & & & 0.0964 & 0.29656 & & & 0.60996 & \\
\hline & 48 & 0.125 & 0.334219 & 0 & 1 & 114 & 91 & 7 & 0 & 1 & 6 & 0.028 \\
\hline \multirow[b]{2}{*}{ q_13_8 } & & 0.14583 & & & & & 0.1140 & 0.31925 & & & 0.59474 & \\
\hline & 48 & 3 & 0.356674 & 0 & 1 & 114 & 35 & 7 & 0 & 1 & 2 & 0.031 \\
\hline \multirow[b]{2}{*}{ q_15_1 } & & 0.39583 & & & & & 0.4824 & 0.50189 & & & 0.31331 & \\
\hline & 48 & 3 & 0.494204 & 0 & 1 & 114 & 56 & 8 & 0 & 1 & 8 & -0.086 \\
\hline \multirow[b]{2}{*}{ q_15_2 } & & 0.70833 & & & & & 0.6315 & 0.48450 & & & 0.34188 & \\
\hline & 48 & 3 & 0.45934 & 0 & 1 & 114 & 79 & 6 & 0 & 1 & 4 & 0.076 \\
\hline \multirow[b]{2}{*}{ q_15_3 } & & 0.58333 & & & & & 0.5789 & 0.49590 & & & 0.95925 & \\
\hline & 48 & 3 & 0.498224 & 0 & 1 & 114 & 47 & 8 & 0 & 1 & 6 & 0.004 \\
\hline \multirow[b]{2}{*}{ q_15_4 } & & & & & & & 0.4298 & 0.49723 & & & 0.92912 & \\
\hline & 48 & 0.4375 & 0.501328 & 0 & 1 & 114 & 25 & 7 & 0 & 1 & 9 & 0.007 \\
\hline & & & & & & & 0.2017 & 0.40308 & & & & \\
\hline q_16_1 & 48 & 0.3125 & 0.468417 & 0 & 1 & 114 & 54 & 2 & 0 & 1 & 0.15668 & 0.110 \\
\hline
\end{tabular}




\begin{tabular}{|c|c|c|c|c|c|c|c|c|c|c|c|c|}
\hline q_16_2 & 48 & $\begin{array}{r}0.47916 \\
7\end{array}$ & 0.504852 & 0 & 1 & 114 & $\begin{array}{r}0.3771 \\
93\end{array}$ & $\begin{array}{r}0.48682 \\
4\end{array}$ & 0 & 1 & $\begin{array}{r}0.23878 \\
2\end{array}$ & 0.101 \\
\hline q_16_3 & 48 & $\begin{array}{r}0.27083 \\
3 \\
\end{array}$ & 0.449093 & 0 & 1 & 114 & $\begin{array}{r}0.3070 \\
18 \\
\end{array}$ & $\begin{array}{r}0.46329 \\
3 \\
\end{array}$ & 0 & 1 & $\begin{array}{r}0.64384 \\
3 \\
\end{array}$ & -0.036 \\
\hline q_16_4 & 48 & $\begin{array}{r}0.27083 \\
3\end{array}$ & 0.449093 & 0 & 1 & 114 & $\begin{array}{r}0.1403 \\
51\end{array}$ & $\begin{array}{r}0.34888 \\
4\end{array}$ & 0 & 1 & 0.07645 & $0.130 *$ \\
\hline q_17_1 & 48 & $\begin{array}{r}0.02083 \\
3\end{array}$ & 0.144338 & 0 & 1 & 114 & $\begin{array}{r}0.0087 \\
72\end{array}$ & $\begin{array}{r}0.09365 \\
9\end{array}$ & 0 & 1 & $\begin{array}{r}0.59547 \\
3\end{array}$ & 0.012 \\
\hline q_17_2 & 48 & $\begin{array}{r}0.45833 \\
3 \\
\end{array}$ & 0.503534 & 0 & 1 & 114 & $\begin{array}{r}0.5877 \\
19 \\
\end{array}$ & $\begin{array}{r}0.49441 \\
8 \\
\end{array}$ & 0 & 1 & $\begin{array}{r}0.13687 \\
7 \\
\end{array}$ & -0.129 \\
\hline q_17_3 & 48 & $\begin{array}{r}0.41666 \\
7 \\
\end{array}$ & 0.498224 & 0 & 1 & 114 & $\begin{array}{r}0.1929 \\
82 \\
\end{array}$ & $\begin{array}{r}0.39638 \\
2 \\
\end{array}$ & 0 & 1 & 0.00722 & $0.223^{*}$ \\
\hline q_17_4 & 48 & $\begin{array}{r}0.29166 \\
7 \\
\end{array}$ & 0.45934 & 0 & 1 & 114 & $\begin{array}{r}0.3771 \\
93 \\
\end{array}$ & $\begin{array}{r}0.48682 \\
4 \\
\end{array}$ & 0 & 1 & 0.29057 & -0.085 \\
\hline q_18_1 & 48 & $\begin{array}{r}0.20833 \\
3 \\
\end{array}$ & 0.410414 & 0 & 1 & 114 & $\begin{array}{r}0.3157 \\
89 \\
\end{array}$ & $\begin{array}{r}0.46688 \\
2 \\
\end{array}$ & 0 & 1 & $\begin{array}{r}0.14758 \\
8 \\
\end{array}$ & -0.107 \\
\hline q_18_2 & 48 & $\begin{array}{r}0.08333 \\
3\end{array}$ & 0.27931 & 0 & 1 & 114 & $\begin{array}{r}0.1578 \\
95\end{array}$ & $\begin{array}{r}0.36625 \\
2\end{array}$ & 0 & 1 & $\begin{array}{r}0.16166 \\
4\end{array}$ & -0.074 \\
\hline q_18_3 & 48 & $\begin{array}{r}0.04166 \\
7 \\
\end{array}$ & 0.201941 & 0 & 1 & 114 & $\begin{array}{r}0.0964 \\
91 \\
\end{array}$ & $\begin{array}{r}0.29656 \\
7 \\
\end{array}$ & 0 & 1 & $\begin{array}{r}0.17570 \\
6 \\
\end{array}$ & -0.054 \\
\hline q_18_4 & 48 & 0.375 & 0.489246 & 0 & 1 & 114 & $\begin{array}{r}0.3508 \\
77\end{array}$ & $\begin{array}{r}0.47935 \\
2 \\
\end{array}$ & 0 & 1 & $\begin{array}{r}0.77382 \\
3\end{array}$ & 0.024 \\
\hline q_18_5 & 48 & 0.25 & 0.437595 & 0 & 1 & 114 & $\begin{array}{r}0.3859 \\
65\end{array}$ & $\begin{array}{r}0.48897 \\
2\end{array}$ & 0 & 1 & $\begin{array}{r}0.08450 \\
9\end{array}$ & $-0.135 *$ \\
\hline q_18_6 & 48 & 0.3125 & 0.468417 & 0 & 1 & 114 & 0.2631 & 0.44229 & 0 & 1 & 0.53543 & 0.049 \\
\hline
\end{tabular}




\begin{tabular}{|l|l|l|l|l|l|l|l|l|l|l|l|}
\hline & & & & & & & 58 & 2 & & 8 & \\
\hline
\end{tabular}


APPENDIX V: Statistical test of differences by Foreign Direct Investment

\begin{tabular}{|c|c|c|c|c|c|c|c|c|c|c|c|c|}
\hline \multirow[b]{2}{*}{ VARIABLE } & \multicolumn{5}{|c|}{ NON-FDI ENTERPRISES } & \multicolumn{5}{|c|}{ FDI ENTERPRISES } & \multirow[b]{2}{*}{ P-Value } & \multirow[b]{2}{*}{ DIFF } \\
\hline & $\mathbf{N}$ & MEAN & SD & MIN & MAX & $\mathbf{N}$ & MEAN & SD & MIN & MAX & & \\
\hline q_9_1 & 162 & 0.185185 & 0.389652 & 0 & 1 & 57 & 0.175439 & 0.383723 & 0 & 1 & 0.869853 & 0.009 \\
\hline q_9_2 & 162 & 0.635802 & 0.482697 & 0 & 1 & 57 & 0.508772 & 0.504367 & 0 & 1 & 0.10152 & 0.127 \\
\hline q_9_3 & 162 & 0.432099 & 0.496904 & 0 & 1 & 57 & 0.421053 & 0.498117 & 0 & 1 & 0.885727 & 0.011 \\
\hline q0010_0001 & 92 & 2.445652 & 0.998506 & 1 & 4 & 23 & 2.869565 & 0.919701 & 1 & 4 & 0.059876 & $\begin{array}{l}- \\
0.423 *\end{array}$ \\
\hline q0010_0002 & 88 & 2.409091 & 1.078913 & 1 & 4 & 22 & 2.909091 & 0.921132 & 1 & 4 & 0.034393 & $-0.5^{*}$ \\
\hline q0010_0003 & 87 & 2.310345 & 1.026513 & 1 & 4 & 20 & 2.8 & 0.833509 & 1 & 4 & 0.030256 & $\begin{array}{l}- \\
0.489 *\end{array}$ \\
\hline q0010_0004 & 90 & 2.811111 & 0.833221 & 1 & 4 & 22 & 3.090909 & 0.811177 & 1 & 4 & 0.158668 & -0.279 \\
\hline q0010_0005 & 89 & 2.842697 & 0.903263 & 1 & 4 & 21 & 3.095238 & 0.624881 & 2 & 4 & 0.137043 & -0.252 \\
\hline q0010_0006 & 83 & 3.180723 & 0.871564 & 1 & 4 & 21 & 3.428571 & 0.676123 & 2 & 4 & 0.16668 & -0.247 \\
\hline q0011_0001 & 87 & 2.494253 & 1.032873 & 1 & 4 & 26 & 2.692308 & 0.788377 & 1 & 4 & 0.302395 & -0.198 \\
\hline q0011_0002 & 94 & 2.62766 & 1.005191 & 1 & 4 & 24 & 2.958333 & 0.999094 & 1 & 4 & 0.157041 & -0.330 \\
\hline q0011_0003 & 89 & 2.044944 & 0.928221 & 1 & 4 & 24 & 2.041667 & 0.907896 & 1 & 4 & 0.987622 & 0.003 \\
\hline q0011_0004 & 91 & 2.714286 & 0.820375 & 1 & 4 & 24 & 2.708333 & 0.750604 & 1 & 4 & 0.973148 & 0.005 \\
\hline q0011_0005 & 93 & 2.827957 & 0.829139 & 1 & 4 & 23 & 2.73913 & 0.810016 & 1 & 4 & 0.64226 & 0.088 \\
\hline q0011_0006 & 87 & 2.471264 & 1.11896 & 1 & 4 & 22 & 2.681818 & 1.170525 & 1 & 4 & 0.452677 & -0.210 \\
\hline q0012_0001 & 91 & 2.164835 & 1.035629 & 1 & 4 & 25 & 2.28 & 1.061446 & 1 & 4 & 0.631905 & -0.115 \\
\hline q0012_0002 & 91 & 2.186813 & 1.031849 & 1 & 4 & 25 & 2.28 & 0.979796 & 1 & 4 & 0.679403 & -0.093 \\
\hline q0012_0003 & 94 & 2.829787 & 0.96874 & 1 & 4 & 26 & 2.923077 & 0.934797 & 1 & 4 & 0.657357 & -0.093 \\
\hline q0012_0004 & 93 & 2.784946 & 0.845055 & 1 & 4 & 24 & 2.75 & 0.84699 & 1 & 4 & 0.857941 & 0.034 \\
\hline q0014_0001 & 91 & 2.527472 & 0.898649 & 1 & 4 & 24 & 2.708333 & 0.954585 & 1 & 4 & 0.409097 & -0.180 \\
\hline
\end{tabular}




\begin{tabular}{|c|c|c|c|c|c|c|c|c|c|c|c|c|}
\hline q0014_0002 & 87 & 2.678161 & 0.970426 & 1 & 4 & 25 & 2.88 & 1.053565 & 1 & 4 & 0.396001 & -0.201 \\
\hline q0014_0003 & 93 & 3.010753 & 0.580379 & 1 & 4 & 25 & 2.76 & 0.663325 & 1 & 4 & 0.094153 & $0.250^{*}$ \\
\hline q_13_1 & 162 & 0.320988 & 0.468304 & 0 & 1 & 57 & 0.333333 & 0.475595 & 0 & 1 & 0.865969 & -0.012 \\
\hline q_13_2 & 162 & 0.246914 & 0.432553 & 0 & 1 & 57 & 0.263158 & 0.444262 & 0 & 1 & 0.811574 & -0.016 \\
\hline q_13_3 & 162 & 0.382716 & 0.487557 & 0 & 1 & 57 & 0.368421 & 0.486664 & 0 & 1 & 0.849199 & 0.014 \\
\hline q_13_4 & 162 & 0.45679 & 0.499674 & 0 & 1 & 57 & 0.315789 & 0.468961 & 0 & 1 & 0.057746 & $0.141 *$ \\
\hline q_13_5 & 162 & 0.641975 & 0.480906 & 0 & 1 & 57 & 0.438596 & 0.500626 & 0 & 1 & 0.009054 & $0.203^{*}$ \\
\hline q_13_6 & 162 & 0.425926 & 0.496016 & 0 & 1 & 57 & 0.350877 & 0.481487 & 0 & 1 & 0.317714 & 0.075 \\
\hline q_13_7 & 162 & 0.104938 & 0.307424 & 0 & 1 & 57 & 0.105263 & 0.30962 & 0 & 1 & 0.994568 & -0.000 \\
\hline q_13_8 & 162 & 0.123457 & 0.329981 & 0 & 1 & 57 & 0.052632 & 0.225282 & 0 & 1 & 0.075276 & $0.070^{*}$ \\
\hline $\mathrm{q}$ _15_1 & 162 & 0.45679 & 0.499674 & 0 & 1 & 57 & 0.473684 & 0.503745 & 0 & 1 & 0.827709 & -0.016 \\
\hline q_15_2 & 162 & 0.654321 & 0.477064 & 0 & 1 & 57 & 0.614035 & 0.49115 & 0 & 1 & 0.592806 & 0.040 \\
\hline q_15_3 & 162 & 0.580247 & 0.495049 & 0 & 1 & 57 & 0.578947 & 0.498117 & 0 & 1 & 0.986497 & 0.001 \\
\hline q_15_4 & 162 & 0.432099 & 0.496904 & 0 & 1 & 57 & 0.385965 & 0.49115 & 0 & 1 & 0.544534 & 0.046 \\
\hline q_16_1 & 162 & 0.234568 & 0.425042 & 0 & 1 & 57 & 0.192982 & 0.398147 & 0 & 1 & 0.506745 & 0.041 \\
\hline q_16_2 & 162 & 0.407407 & 0.492875 & 0 & 1 & 57 & 0.350877 & 0.481487 & 0 & 1 & 0.450427 & 0.056 \\
\hline q_16_3 & 162 & 0.296296 & 0.458039 & 0 & 1 & 57 & 0.210526 & 0.411306 & 0 & 1 & 0.191741 & 0.085 \\
\hline q_16_4 & 162 & 0.179012 & 0.384551 & 0 & 1 & 57 & 0.263158 & 0.444262 & 0 & 1 & 0.206717 & -0.084 \\
\hline q_17_1 & 162 & 0.012346 & 0.110766 & 0 & 1 & 57 & 0.017544 & 0.132453 & 0 & 1 & 0.791317 & -0.005 \\
\hline q_17_2 & 162 & 0.549383 & 0.499098 & 0 & 1 & 57 & 0.421053 & 0.498117 & 0 & 1 & 0.097697 & $0.128^{*}$ \\
\hline q_17_3 & 162 & 0.259259 & 0.439587 & 0 & 1 & 57 & 0.333333 & 0.475595 & 0 & 1 & 0.305207 & -0.074 \\
\hline q_17_4 & 162 & 0.351852 & 0.479029 & 0 & 1 & 57 & 0.45614 & 0.5025 & 0 & 1 & 0.17584 & -0.104 \\
\hline q_18_1 & 162 & 0.283951 & 0.452311 & 0 & 1 & 57 & 0.22807 & 0.423318 & 0 & 1 & 0.401834 & 0.055 \\
\hline q_18_2 & 162 & 0.135802 & 0.343641 & 0 & 1 & 57 & 0.070175 & 0.257713 & 0 & 1 & 0.133998 & 0.065 \\
\hline q_18_3 & 162 & 0.080247 & 0.272517 & 0 & 1 & 57 & 0.070175 & 0.257713 & 0 & 1 & 0.803124 & 0.010 \\
\hline
\end{tabular}




\begin{tabular}{|c|c|c|c|c|c|c|c|c|c|c|c|c|}
\hline q_18_4 & 162 & 0.358025 & 0.480906 & 0 & 1 & 57 & 0.263158 & 0.444262 & 0 & 1 & 0.177806 & 0.094 \\
\hline q_18_5 & 162 & 0.345679 & 0.477064 & 0 & 1 & 57 & 0.333333 & 0.475595 & 0 & 1 & 0.866596 & 0.012 \\
\hline q_18_6 & 162 & 0.277778 & 0.449292 & 0 & 1 & 57 & 0.22807 & 0.423318 & 0 & 1 & 0.454816 & 0.049 \\
\hline
\end{tabular}

